\title{
DIVERSIDADE GENÉTICA E SISTEMA DE CRUZAMENTO EM POPULAÇÕES NATURAIS DE DUAS ESPÉCIES PIONEIRAS ARBÓREAS
}

\section{LUCIANO ARRUDA RIBAS}

Tese apresentada à Escola Superior de Agricultura "Luiz de Queiroz”, Universidade de São Paulo, para obtenção do título de Doutor em Agronomia, Área de Concentração: Genética e Melhoramento de Plantas.

PIR A CIC A B A

Estado de São Paulo - Brasil

Julho - 2003 


\section{DIVERSIDADE GENÉTICA E SISTEMA DE CRUZAMENTO EM POPULAÇÕES NATURAIS DE DUAS ESPÉCIES PIONEIRAS ARBÓREAS}

\section{LUCIANO ARRUDA RIBAS}

Engenheiro Florestal

Orientador: Prof. Dr. PAULO YOSHIO KAGEYAMA

Tese apresentada à Escola Superior de Agricultura "Luiz de Queiroz”, Universidade de São Paulo, para obtenção do título de Doutor em Agronomia, Área de Concentração: Genética e Melhoramento de Plantas.

P I R A C I C A B A

Estado de São Paulo - Brasil

Julho - 2003 


\section{Dados Internacionais de Catalogação na Publicação (CIP) DIVSÃO DE BIBLIOTECA E DOCUMENTAC̄̃OO - ESALQ/USP}

\section{Ribas, Luciano Amuda}

Diversidade genética e sistema de cruzamento em populações natura is de duas espécies pioneiras arbóreas/ Luciano Amuda Ribas. - - Piracicaba, 2003.

$102 \mathrm{p}$.

Tese (doutorado) - Escola Superior de Agric ultura Luiz de Queiroz, 2003. Bibliografia.

1. Crindiuva 2. Cruzamento vegetal 3. Desmatamento 4. Embauba 5. Impactos a mbienta is 6. Populações vegeta is 7. Sementes 8. Variação genética em plantas I. Título 


\begin{abstract}
À minha Aninha,
Pelo companheirismo e bons momentos já vividos,

E ao nosso filhotinho,

pelos momentos felizes que viveremos juntos.
\end{abstract}




\section{AGRADECIMENTOS}

Ao Professor Dr. Paulo Yoshio Kageyama pela orientação, assinaturas e agradáveis momentos sociais.

Ao Departamento de Genética, pela oportunidade de realizar o curso.

À Coordenação de Aperfeiçoamento de Pessoal de Nível Superior (CAPES), pela bolsa de estudos durante os seis meses iniciais do curso, e à Fundação de Amparo à Pesquisa do Estado de São Paulo (FAPESP), pelo apoio financeiro, sob a forma de bolsa de estudos e reserva técnica.

À Elza Ferraz, Gelson Fenandes e Andréia Moreno, pelo apoio durante viagens a campo, nas atividades burocráticas e laboratoriais e pela valiosa presença ao longo dos vários dias em laboratório.

Aos colegas que compartilharam do LARGEA no início do curso: Helena Maltez, Alexandre, Bia, Cobrão, Márcia, Milene, Marta, Pêra, Taís, Patrícia, Giuliana, Carioca, e nos dias mais recentes: Fernandinha, Dodô, Cipó, Karina, Sybelle, Nivaldo, Gauchinha. Aos colegas Alexandre Magno Sebbenn, Maria Beatriz Perecin, Flávio Gandara e ao Prof. Dr. Roland Vencovsky pelas sugestões dadas durante alguma fase deste trabalho, e à Profa. Dra. Elizabeth Ann Veasey pelas correções do inglês, feitas de última hora.

De forma discreta, agradeço aos “colegas do social”, os quais foram imprescindíveis para a realização deste trabalho. 


\section{SUMÁRIO}

Página

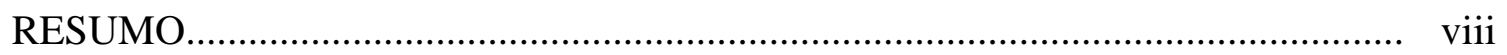

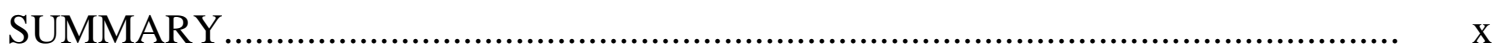

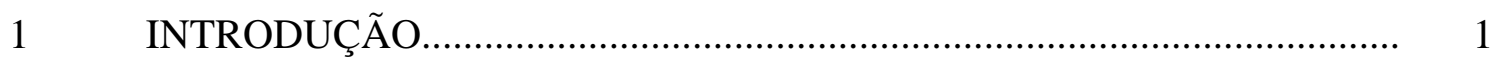

2 REVISÃO DE LITERATURA..............................................................

$2.1 \quad$ As florestas tropicais............................................................................ 3

$2.2 \quad$ Espécies pioneiras na sucessão..................................................................... 5

2.3 Efeitos da fragmentação..........................................................................

3 SISTEMA DE CRUZAMENTO DE DUAS ESPÉCIES PIONEIRAS DA

FLORESTA TROPICAL: Trema micrantha (L.) B. e Cecropia pachystachya Tre., AVALIADOS EM FRAGMENTOS FLORESTAIS...... 11

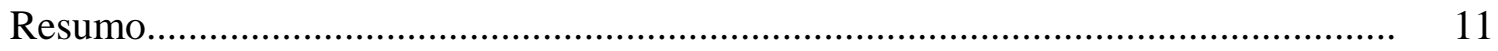

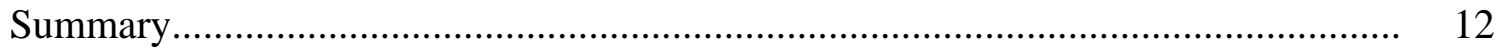

3.1 Introdução....................................................................................... 13

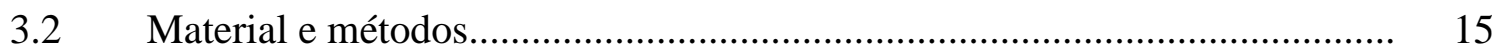

3.2.1 Caracterização das espécies....................................................................... 15

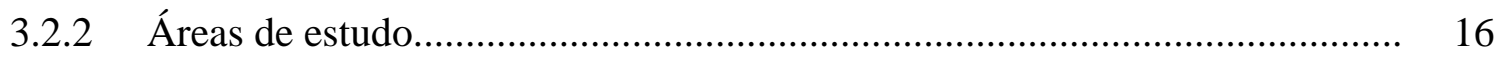

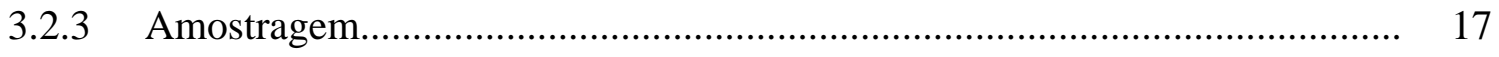

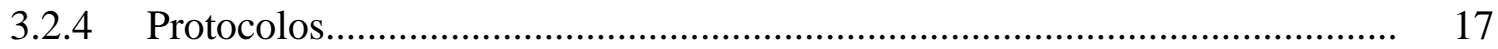

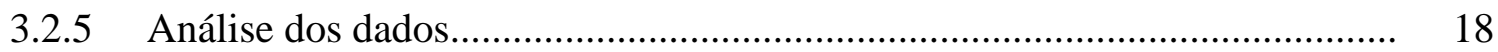

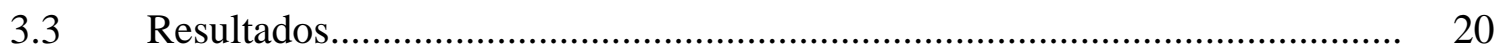

3.3.1 Teste de Equilíbrio de Hardy-Weinberg...................................................... 20

3.3.2 Homogeneidade nas freqüências alélicas dos óvulos e pólen......................... 21

3.3.3 Sistema de cruzamento................................................................................ 25 
3.4 Discussão.................................................................................. 29

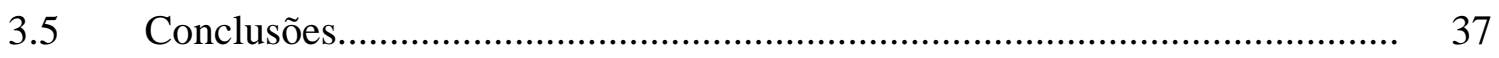

4 DIVERSIDADE E ESTRUTURA GENÉTICA EM POPULAÇÕES

NATURAIS DE Trema micrantha Trec. E Cecropia pachystachya (L.) B... 38

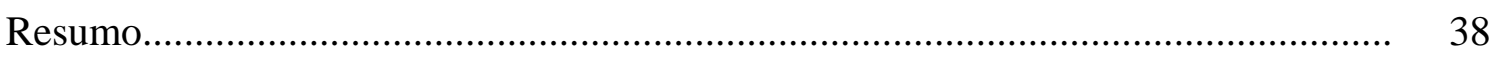

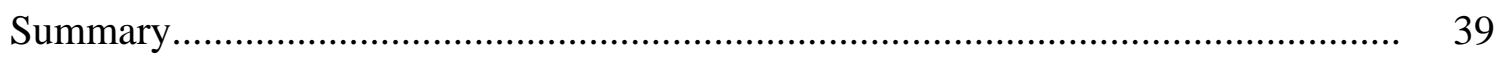

4.1 Introdução......................................................................................... 39

4.2 Material e métodos.................................................................................. 42

4.2.1 Espécies estudadas.................................................................................... 42

4.2.2 Locais de estudo....................................................................................... 43

4.2.3 Amostragem.................................................................................... 44

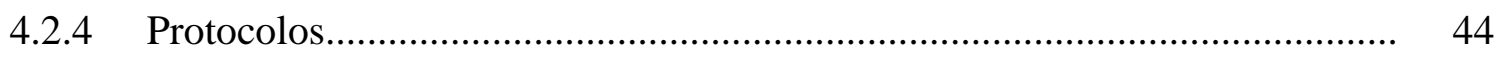

4.2.5 Análises estatísticas.................................................................................. 45

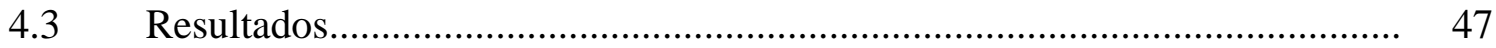

4.3.1 Freqüências alélicas..................................................................................... 47

4.3.2 Diversidade genética................................................................................ 52

4.3.3 Estrutura genética............................................................................... 54

4.4 Discussão.................................................................................... 56

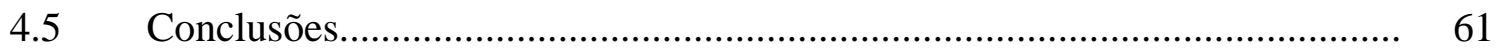

5 ESTRUTURA GENÉTICA EM DIFERENTES ESTÁDIOS DE VIDA EM UMA POPULAÇÃO DE Trema micrantha (L.)B. ............................... 62

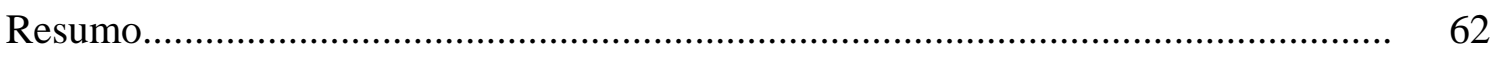

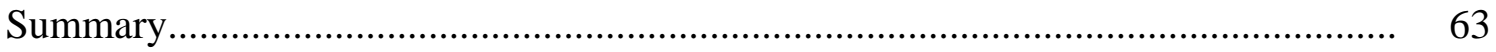

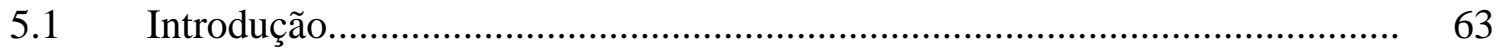

$5.2 \quad$ Material e métodos................................................................................ 66

5.2.1 Espécies estudadas................................................................................ 66

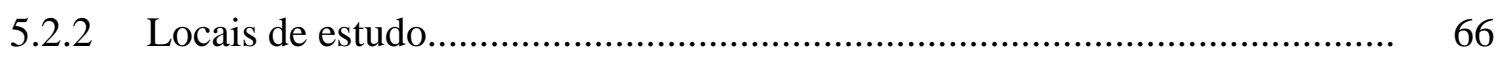

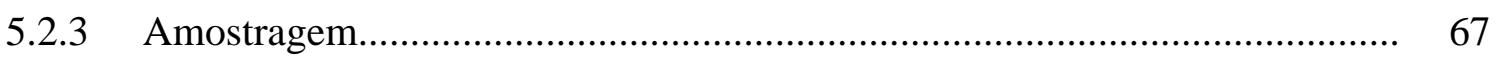

Banco de sementes do solo..................................................................... 67

Plantas do dossel.................................................................................. 68 
Progênies........................................................................................... 68

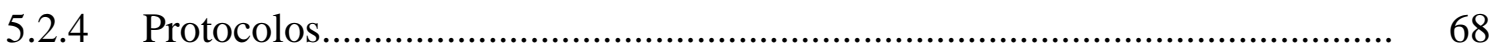

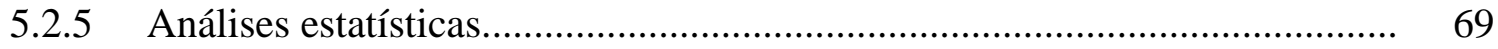

5.2.6 Comparações entre estádios de vida.......................................................... 70

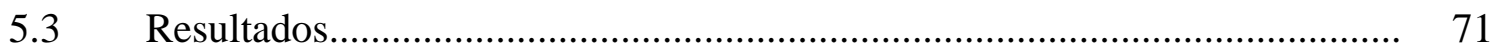

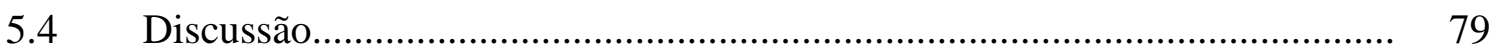

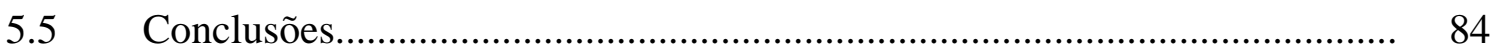

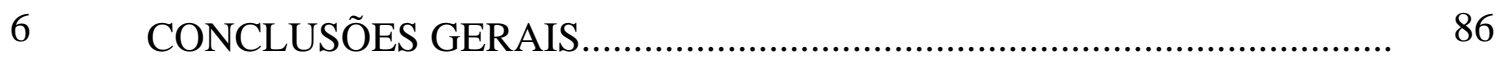

REFERÊNCIAS BIBLIOGRÁFICAS............................................................ 88

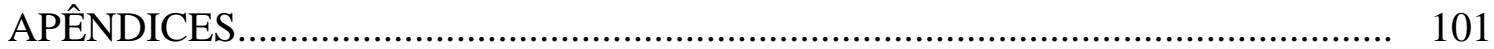




\title{
DIVERSIDADE GENÉTICA E SISTEMA DE CRUZAMENTO EM POPULAÇÕES NATURAIS DE DUAS ESPÉCIES PIONEIRAS ARBÓREAS
}

\author{
Autor: LUCIANO ARRUDA RIBAS \\ Orientador: Prof. PAULO YOSHIO KAGEYAMA
}

\section{RESUMO}

O conhecimento sobre o sistema de cruzamento e a forma como a diversidade genética está distribuída em populações de espécies arbóreas é de fundamental importância para se planejar seu manejo e conservação. Espécies arbóreas pioneiras estão cada vez mais freqüentes dentro e fora dos fragmentos florestais remanescentes. Trema micrantha é uma das primeiras espécies a se estabelecer em áreas abandonadas e Cecropia pachystachya é uma espécie pioneira dióica e seletivamente higrófita. Ambas são polinizadas pelo vento e produzem muitas sementes que são dispersas por animais. Estudou-se a diversidade e estrutura genética e o sistema de cruzamento em populações de ambas espécies e, para T. micrantha, avaliou-se também o banco de sementes como um potencial tampão gênico para a espécie. As populações foram amostradas na Estação Ecológica dos Caetetus (Gália-S.P.) e na Reserva Florestal de Santa Genebra (Campinas-S.P.), onde se amostrou 177 indivíduos de T. micrantha, distribuídos em 6 e 5 subpopulações, e 178 indivíduos de C. pachystachya, em 2 e 3 subpopulações, nos respectivos fragmentos. Os sistemas de cruzamento foram avaliados com base em 24 progênies de 10 indivíduos por progênie de cada espécie. As estimativas para os 
parâmetros de diversidade genética nas populações de plantas do dossel foram obtidas a partir do polimorfismo de oito locos isoenzimáticos, num total de 20 alelos para $T$. micrantha e sete locos isoenzimáticos num total de 17 alelos para C. pachystachya. Da mesma forma, utilizou-se 13 locos com 30 alelos para T. micrantha e sete locos com 17 alelos para C. pachystachya, no estudo dos sistemas de cruzamento. Verificou-se que as populações de ambas espécies contêm baixos níveis de endogamia ( f f de -0,204 e 0,066 em T. micrantha; -0,052 e 0,049 em C. pachystachya, em ambos fragmentos) e alta diversidade ( $H_{e}$ de 0,373 e 0,392 em T. micrantha; 0,355 e 0,335 em C. pachystachya, em ambos fragmentos). A divergência genética existente entre populações é menor do que entre subpopulações ( $\hat{\theta}_{p}$ de 0,026 e $-0,007, \hat{\theta}_{S P}$ de 0,086 e 0,068, para $C$. pachystachya e T. micrantha, respectivamente). T. micrantha apresenta sistema de cruzamento misto, com preferência por alogamia $\left(\hat{t}_{m}\right.$ de 0,966 e 0,819 , em ambos fragmentos) e está sujeita a variações na freqüência de cruzamentos endogâmicos ( $\hat{F}$ de $-0,022$ e 0,103$)$ e a altas taxas de cruzamentos biparentais ( $\hat{r}_{p}$ de 0,653 e 0,605$)$. Sendo espécie dióica, as estimativas de fecundação cruzada obtidas para C. pachystachya não corresponderam às expectativas $\left(\hat{t}_{m}\right.$ de 0,816 e 0,794$)$. No entanto, as estimativas indicaram que espécie está sujeita a cruzamentos biparentais ( $\hat{r}_{p}$ de 0,868 e 0,990$)$. Os resultados sugerem que uma acirrada competição nas etapas de germinação e desenvolvimento de plântulas durante a regeneração de T. micrantha, bem como a distribuição espacial em clareiras e o eficiente fluxo gênico nesta espécie são fundamentais para manter altas taxas de diversidade genética em suas populações. 


\title{
GENETIC DIVERSITY AND MATING SYSTEMS IN NATURAL POPULATIONS OF TWO PIONEERS TREE SPECIES
}

\author{
Author: LUCIANO ARRUDA RIBAS \\ Adviser: Prof. PAULO YOSHIO KAGEYAMA
}

\section{SUMMARY}

The knowledge about the breeding system and the genetic structure of populations of tree species is of great importance in order to plan their management and conservation. Pioneer tree species are more and more frequent inside and outside remaining forest fragments. Trema micrantha is one of the first tree species to be established in abandoned areas and Cecropia pachystachya is a pioneer dioecious tree and selectively adapted to wet soils. Both species are pollinated by wind and produce seeds that are dispersed by various animals species. We studied the diversity, the genetic structure and the mating system of both pioneer species populations. The seed bank of T. micrantha was also evaluated as a potential genetic buffer for this species. Populations were collected in the “Estação Ecológica dos Caetetus” (Gália, São Paulo State, Brazil) and in the "Reserva Florestal de Santa Genebra” (Campinas, São Paulo State, Brazil), where 177 plants of T. micrantha, distributed into six and five subpopulations, and 178 plants of C. pachystachya, distributed into two and three subpopulations were respectively sampled from both fragments. Ten seeds per plant and 24 plants per population were germinated to generate progeny arrays used in the mating system analyses. The 
estimates for the genetic diversity genetic parameters in the plant populations of the dossel were obtained from eight polymorphic isozyme loci with 20 alleles for $T$. micrantha and seven isoenzymatic loci with 17 alleles for C. pachystachya. Similarly, 13 loci with 30 alleles for $T$. micrantha and seven loci with 17 alleles for $C$. pachystachya were used in the mating system study. The results showed that populations of both species have low levels of inbreeding ( $\hat{f}=-0.204$ and 0.066 for T. micrantha; $\hat{f}=-0.052$ and 0.049 for $C$. pachystachya, in both fragments, respectively) and high diversity ( $\hat{H} e=0.373$ and 0.392 for T. micrantha; $\hat{H} e=0.355$ and 0.335 for $C$. pachystachya, in both fragments). The genetic divergence among populations was lower than among subpopulations $\left(\hat{\theta}_{p}=0.026\right.$ and $-0.007 ; \hat{\theta}_{S P}=0.086$ and 0.068 , for $C$. pachystachya and T. micrantha, respectively). T. micrantha presents a mixed mating system, with preference to outcrossing ( $\hat{t}_{m}=0.966$ and 0.819 , in both fragments) and is subject to variations in the inbreeding frequency and high rates of biparental mating ( $\hat{r}_{p}=0.653$ and 0.605 in both fragments, respectively). The estimates obtain for $C$. pachystachya did not correspond to the expectations of a dioecious species $\left(\hat{t}_{m}=0.816\right.$ and 0.794 in both fragments). A significant proportion of related individuals were observed ( $\hat{t} m-\hat{t} s=0.072$ and 0.128 , both fragments), indicating a spacial structure of individuals under the species natural condition. The estimates showed that the great majority of $C$. pachystachya progenies are composed of full-sib matings $\left(\hat{r}_{p}=0.868\right.$ and 0.990 in both fragments), resulting from biparental matings. Besides, the results suggest that a tough competition in the phases of germination and seedling development during the regeneration of $T$. micrantha, as well as the spatial distribution in gaps and the efficient gene flow are important in order to maintain high rates of genetic diversity in its populations. 


\section{INTRODUÇÃO}

As florestas tropicais são admiradas por todo o mundo devido sua biodiversidade, caracterizando-se por uma grande heterogeneidade no modo de ocorrência de suas espécies e pela diversidade genética nas mesmas. A diversidade genética existente em populações naturais deve ser quantificada e avaliada quanto à sua distribuição entre e dentro de populações, devido sua distribuição apresentar grande variação por ser influenciada pelo tamanho efetivo populacional, ocorrência geográfica das espécies, modo de reprodução e sistema de cruzamento, pelos mecanismos de dispersão de sementes e até mesmo pelo estágio de sucessão ecológica da espécie em questão. Estudos sobre genética de populações de espécies arbóreas tropicais vêm sendo desenvolvidos para espécies representantes dos diferentes grupos ecológicos sucessionais. Seus resultados tendem a proporcionar maior conhecimento da genética de populações dessas espécies e de várias outras espécies com características populacionais semelhantes, oferecendo maiores subsídios para se planejar a melhor maneira de se realizar o manejo das espécies, seu uso na restauração de áreas degradadas, na formação de corredores de fluxo gênico, bem como compreender melhor os tamanhos mínimos de reservas e desenvolver programas de coleta de sementes.

Espécies pioneiras possuem características próprias de extinção local e recolonização que, juntamente com a existência de banco de sementes e a longa distância de dispersão de pólen e sementes, apresentam importantes conseqüências genéticas e ecológicas para as espécies. Exemplos claros são os bancos de sementes poderem agir como "tampão gênico" devido sua capacidade de repor a diversidade genética perdida pela população de plantas e a longa distância de dispersão de sementes e pólen reduzir a distância entre populações geograficamente distantes (Alvarez-Buylla 
\& Garay, 1994). Sob este aspecto, percebe-se que a similaridade genética entre a população do banco de sementes do solo com a de plantas adultas da mesma espécie, depende de características do sistema de cruzamento e de variações, no tempo e espaço, na produção e sobrevivência de sementes e plântulas. A distância de dispersão de sementes, bem como os fatores que afetam a longevidade das mesmas no banco de sementes do solo, são tão importantes quanto as variações na fecundidade e posterior sobrevivência de suas plântulas. Da mesma forma, a proporção de mudas resultantes da germinação de sementes do banco de sementes do solo em relação àquelas originadas do último evento reprodutivo, também são responsáveis pela dinâmica da população de plantas da mesma espécie (Tonsor et al. 1993). Obviamente, o entendimento das mudanças entre a população do banco de sementes e das plantas adultas depende de um vasto conjunto de informações.

\section{Objetivos gerais}

Os principais objetivos deste trabalho foram:

1- Estimar a diversidade genética e avaliar sua distribuição em populações naturais das espécies pioneiras arbóreas: Trema micrantha e Cecropia pachystachya;

2- Determinar o sistema de cruzamento em populações dessas duas espécies pioneiras;

3- Avaliar o impacto da fragmentação florestal sobre a diversidade genética e o sistema de cruzamento nas populações de ambas espécies;

4- Avaliar a influência do banco de sementes na manutenção da diversidade genética de Trema micrantha. 


\section{REVISÃO DE LITERATURA}

\subsection{As florestas tropicais}

As florestas tropicais ocupam cerca de 7\% da superfície do planeta, mas estimase que contenham mais de 50\% do total das espécies existentes. Sua área original de 16 milhões de $\mathrm{km}^{2}$ estava reduzida, já em 1985, a 10,5 milhões $\mathrm{km}^{2}$ e estima-se que são

perdidos cerca de $180.000 \mathrm{~km}^{2}$ por ano (Myers, 1991; Sayer \& Whitmore, 1991). Referindo-se à Mata Atlântica, apenas 5\% da sua área original ainda se mantém em pé (Myers, 1986), estando reduzida a fragmentos isolados que, provavelmente, não dão suporte às populações de muitas espécies de ampla extensão natural. Os solos do Estado de São Paulo, particularmente, suportaram florestas tropicais semidecíduas. Hoje, possuem extensas áreas destinadas à agricultura e pecuária, sendo que o planalto existente logo após as escarpas da Serra do Mar foi um dos primeiros habitats a ser destruído (Primack \& Rodrigues, 2001).

Verifica-se, portanto, que as comunidades biológicas existentes variam daquelas que estão praticamente intactas àquelas que estão, em grande parte, alteradas pela ação do homem. Ao mesmo tempo, mesmo nas áreas mais remotas, pode-se observar a ação do ser humano e, naquelas bastante alteradas pelo homem, ainda encontra-se remanescentes da biota original. De qualquer forma, são os habitats em níveis intermediários de perturbação que consistem em um dos mais interessantes desafios e oportunidades para conservação biológica, por ocuparem maiores áreas (Bazzaz, 1991).

Dada sua incrível biodiversidade, os ecossistemas tropicais são extremamente complexos e se caracterizam por extraordinárias interações entre espécies da sua flora e fauna. Sobretudo, estando as florestas reduzidas a fragmentos, estas são fortemente 
influenciadas por efeitos de borda, que correspondem às mudanças ecológicas associadas à ocorrência abrupta de bordas artificiais. As mudanças de radiação solar, temperatura, umidade e velocidade dos ventos que penetram a floresta resultam em alterações no seu microclima, acarretando mudanças na composição de espécies das comunidades florestais após a fragmentação (Murcia, 1995). Em função do aumento da turbulência e do estresse hídrico, as taxas de mortalidade de árvores aumentam drasticamente próximo às bordas, levando à maior freqüência de formação de clareiras que alteram a estrutura e a composição da floresta (Laurence et al. 1998). Estudos sugerem que os fragmentos abaixo de 100-400 ha são bastante alterados ecologicamente e que a grande maioria dos fragmentos florestais em paisagens antrópicas estão nesta classe de tamanho ou abaixo desta (Primack \& Rodrigues, 2001).

A fragmentação de contínuos florestais pode resultar em grandes prejuízos para toda a comunidade biológica. Como exemplo, enquanto a redução do tamanho efetivo em populações de árvores representa uma diminuição no número de indivíduos reprodutivos e na quantidade de pólen depositado, ela também pode refletir na abundância de agentes polinizadores (Powell \& Powell, 1987; Sih \& Baltus, 1987; Jennersten, 1988; Klein, 1989; Aizen \& Feinsinger, 1994). Fragmentos florestais pequenos e isolados tendem a experimentar uma redução na taxa de fluxo de pólen (Bawa, 1990), o qual pode afetar negativamente na produção de frutos e na qualidade e quantidade das sementes produzidas (Cunningham, 2000). A fragmentação florestal também afeta na predação e dispersão de sementes e nos níveis de herbivoria sobre as população de plantas remanescentes. Efeitos de borda associados com a fragmentação florestal diminuem a chuva de sementes e o estabelecimento de mudas de espécies tropicais (Benitez-Malvido, 1998; Benitez-Malvido et al. 1999; Bruna, 1999).

No entanto, o tipo e intensidade do distúrbio depende da natureza do processo de uso da terra que ocorre nas diferentes regiões alteradas, tendo influência no padrão de recuperação natural do ecossistema. Em vista do problema, muitos estudos têm sido realizados com o objetivo de conhecer melhor os processos naturais de recuperação em pastagens (Uhl et al. 1988), áreas cultivadas para agricultura (Wiesenmüller et al. 1995) e floresta alterada (Viana, 1990). 


\subsection{Espécies pioneiras na sucessão}

Estudos sobre a dinâmica de florestas tropicais têm sido desenvolvidos, sendo um grande desafio entender sua estrutura, a organização das comunidades, a dinâmica das populações, bem como as especiações e as variações fisiológicas que atribuem características demográficos e comportamentais que sustentam o processo. Sabendo-se que as florestas tropicais são potencialmente importante fonte de alimento, madeira e medicamentos, tem-se tentado desenvolver práticas de manejo baseadas num entendimento da biologia básica de árvores e seu ambiente. Devido sua grande importância no manejo florestal, a dinâmica da regeneração após a exploração tem recebido particular atenção (Bazzaz, 1991).

A sucessão secundária em comunidades de plantas não é tão constante e previsível. Como citado em Whitmore (1991), existem dois modelos básicos para se explicar o processo de sucessão, sendo que, na realidade, eles não são mutualmente exclusivos. No primeiro, um grupo de espécies invasoras ou pioneiras é posteriormente substituído por espécies climácicas, tolerantes à sombra. Num modelo alternativo, espécies com variações na tolerância à sombra colonizam, às vezes simultaneamente, durante o primeiro ou segundo ano, sendo que algumas crescem mais rapidamente e são mais dominantes nos anos iniciais da sucessão. As mais exigentes por luz crescem rapidamente e, normalmente, são de vida mais curta do que as menos exigentes, morrendo e deixando que o segundo grupo torne-se dominante. Fora as espécies pioneiras e climácicas, pode-se ainda distinguir um grupo de espécies que ocupam após a colonização inicial, tornando-se dominantes na fase entre as pioneiras de rápido crescimento e as espécies climácicas de crescimento bem lento. Budowski (1965) as classifica como secundárias tardias, sendo muitas delas comercialmente valiosas.

Mudas de espécies pioneiras não estão presentes no momento em que uma grande clareira é criada. Elas se desenvolvem de sementes que já estavam presentes no solo como um banco de sementes ou daquelas que chegaram após abertura da clareira como chuva de sementes. Os estudos têm mostrado que, no solo das florestas úmidas, existem banco de sementes e que sua germinação é estimulada por mudanças na 
qualidade da luz ou pela elevação da temperatura na superfície do solo (respostas fotoblástica e termoblástica) (Whitmore, 1991). No entanto, ainda existe muito para ser desvendado sobre variações espacial e temporal no banco de sementes no solo.

De forma geral, espécies pioneiras são intolerantes à sombra e dependentes de luz, além de terem hábito nômade, por estarem associadas a eventos de colonização e extinção local. Elas produzem, anualmente e por longos períodos, sementes pequenas que são dispersas pelo vento ou animais, por médias a longas distâncias; sendo que tais sementes permanecem no solo durante bom tempo, compondo o banco de sementes da espécie. Suas plantas são muito bifurcadas e possuem raízes superficiais, apresentando rápido crescimento e produzindo madeira macia e de baixa densidade. Suas folhas são repostas periodicamente, realizam alta taxa fotossintética e respiratória, apresentam baixa toxidade e são susceptíveis à predação por herbívoros e patógenos. As espécies pioneiras apresentam alta fenotipoplasticidade e ampla ocorrência geográfica por possuírem alto potencial de aclimatação e rápida resposta às mudanças nos níveis de recursos (Bazzaz, 1991).

As espécies pioneiras têm se tornado cada vez mais freqüentes nas florestas e fora delas. Devido à taxa de substituição de árvores em florestas consideradas primárias, cerca de $1 \%$ das árvores morrem anualmente e, considerando que existem poucas áreas de florestas tropicais sem influência antrópica, subentende-se freqüentes aberturas de clareiras com diferentes dimensões e por vários motivos (Whitmore, 1991). Além disso, a maioria das espécies pioneiras, e muitas secundárias, possuem características desejáveis para compor os diversos tipos de programas de restauração vegetal, estando cada vez mais presentes fora das suas condições naturais.

\subsection{Efeitos da fragmentação}

Devido suas características reprodutivas e demográficas, árvores tropicais são particularmente vulneráveis aos efeitos da fragmentação florestal. A maioria das espécies arbóreas tropicais ocorrem em baixa densidade, dependem de animais para realizar a polinização e dispersão de suas sementes, apresentam altas taxas de 
fecundação cruzada e sistemas reprodutivos que envolvem complexos mecanismos de auto-incompatibilidade (Bawa, 1974; Hamrick \& Murawski, 1990). Dessa forma, a fragmentação de contínuos florestais resultando em pequenos e separados remanescentes pode causar prejuízos na genética das populações de espécies arbóreas, como mudanças na estrutura genética das populações remanescentes (Loveless \& Hamrick, 1984; Hamrick et al. 1992; Nason \& Hamrick, 1997). A redução do tamanho original da população e, consequentemente, do número total de indivíduos reprodutivos aumenta a probabilidade de cruzamentos entre indivíduos aparentados. Isto, a longo prazo, pode proporcionar a perda de diversidade genética nas populações remanescentes devido aos fatores associados com endogamia e deriva genética (Menges, 1991; Ellstrand \& Elam, 1993).

Os resultados dos trabalhos sobre os efeitos da fragmentação florestal na genética de populações variam entre as espécies arbóreas. Prejuízos da fragmentação de contínuos florestais podem ocorrer devido às populações remanescentes se tornarem menores do que o tamanho de vizinhança natural, como verificado por Boshier et al. (1995) para a espécie Cordia alliodora (Ruiz \& Pav.) Cham., que apresenta uma área de vizinhança de aproximadamente 7 ha, sendo esta área proporcionalmente menor do que vários fragmentos florestais que existem na Costa Rica.

Da mesma forma, Hall et al. (1996) identificaram significativa redução na diversidade genética e aumento da divergência genética entre populações sob efeito da fragmentação, para Pithecellobium elegans. Sendo espécie de árvores emergentes no dossel, polinizada por insetos e dispersa por vento, os autores verificaram que, com o aumento da distância dos fragmentos em relação a uma grande população intacta na Costa Rica, aumentava-se o efeito da fragmentação sobre o fluxo gênico interpropulacional na espécie.

Também Prober \& Browns (1994) demonstraram efeitos parecidos de isolamento de populações, na diversidade genética. Pequena população de Eucalyptus albens ( $<500$ indivíduos reprodutivos) que estava a menos de $250 \mathrm{~m}$ de uma grande população tinha alta riqueza alélica, enquanto populações mais isoladas de tamanho similar se viram geneticamente depouperadas. Ambos resultados alertaram para a importância do fluxo 
gênico a partir de uma grande população na manutenção da diversidade genética. Além disto, os autores encontraram uma relação positiva entre o tamanho das populações remanescentes e a heterozigosidade, sugerindo que a diminuição na heterozigosidade acompanha a redução da população. A diminuição observada de variação foi maior do que esperada devido ao gargalo e deriva genética isoladamente e, presumiu-se num aumento de endogamia.

Por outro lado, Nason \& Hamrick (1997) examinaram o fluxo gênico dentro de pequenas populações em florestas fragmentadas da espécie arbórea Spodias mombin, no Panamá. A espécie é de estágio inicial de sucessão, polinizada por insetos, hermafrodita e de dossel. Com marcador isoenzimático e genótipos de progênies, os autores verificaram que a migração de pólen entre fragmentos ocorre para, no mínimo, metade dos eventos de cruzamentos nas populações analisadas, mesmo com a distância de isolamento de um quilômetro. Isto sugere que, para esta espécie, os eventos de fluxo gênico podem não ter sido truncados pela fragmentação.

Da mesma forma, Foré et al. (1992) compararam a divergência genética interpopulacional obtida em pré-fragmentação com a pós-fragmentação de 15 populações de Acer saccharum Marshall, em Ohio, nos EUA. A espécie é polinizada tanto por insetos como pelo vento e suas sementes são dispersadas por vento. A diversidade genética entre populações estimada na pós-fragmentação foi menor do que a metade daquela estimada na pré-fragmentação, sugerindo aumento no fluxo gênico interpopulacional. Diante das condições, os autores atribuíram a redução da divergência genética ao aumento na velocidade do vento através dos campos que separavam os fragmentos.

Trabalhando com a mesma espécie no Canadá, Young et al. (1993) encontraram aumento significativo no fluxo entre populações na paisagem fragmentada. Baseados na ocorrência de alelos alozimáticos nas populações de Acer saccharum, os autores compararam a amostragem realizada sobre fragmentos com uma outra realizada em equivalente sítio na floresta intacta. Combinado com maior polimorfismo médio nas populações fragmentadas, os resultados também apontaram para aumento de fluxo gênico interpopulação como uma conseqüência da fragmentação para esta espécie. 
Fazendo comparações diretas do padrão de cruzamento entre populações fragmentadas e intactas de espécies florestais, Schmidt-Adam et al. (2000) compararam taxas de fecundação cruzada entre duas populações intactas em ilhas e três populações fragmentadas de Metrosideros excelsa Sol ex Goertm, espécie arbórea polinizada por pássaros, na Nova Zelândia. Esperava-se encontrar maiores taxas de autofecundação nas populações mantidas em fragmentos porque nestes foram encontrados somente uma das três espécies de pássaros polinizadores presentes nas populações intactas. No entanto, não existiu considerável diferença nos níveis de autofecundação entre as populações fragmentadas e as intactas, nem diminuição na heterozigosidade em progênies das diferentes condições. Tal resultado sugeriu que espécies de pássaros exóticos podem ter exercido o papel das espécies nativas perdidas nas populações mantidas nos fragmentos.

Em contraste com a resiliência aparente do sistema de cruzamento de M. excelsa diante da fragmentação, Young et al. (1999) encontraram significativas mudanças no padrão de cruzamento em populações remanescentes de tamanho reduzido e grande isolamento de Rutidoris leptorrhynchoides. Embora as taxas de fecundação cruzada não tenham sido afetadas devido à forte auto-incompatibilidade nesta espécie, existiu clara mudança no padrão de paternidade. Populações pequenas ( $<10$ plantas) ou médias (100 a 200 plantas), isoladas por mais do que 5 quilômetros, exibiram aumento na probabilidade de produção de progênies irmãs-completas, em relação às grandes populações (> 10.000 plantas) ou àquelas de tamanho médio e a 2 quilômetros de uma grande. Embora aparentemente sem endogamia, este aumento na produção de irmãos completos, combinado com limitada dispersão de sementes nesta espécie, descreveu a possibilidade de significativa endogamia por cruzamentos biparentais nas gerações futuras.

No trabalho de Murawski et al. (1994) sobre as taxas de fecundação cruzada de duas espécies endêmicas (Shorea congestiflora e S. trapezifolia), os autores verificaram uma mistura de autofecundação e fecundação cruzada em algumas famílias de $S$. congestiflora e considerou que seria decorrente de um fraco sistema de autoincompatibilidade em alguns indivíduos. Para S. trapezifolia, os autores verificaram uma variação de completa fecundação cruzada para completa autofecundação. Tal variação já 
foi visto para Ceiba pentandra e Cavanillesia platanifolia (Murawski et al, 1990; Murawski \& Hamrick, 1992a, 1992b), indicando que a espécie é auto compatível. A $S$. trapezifolia, assim como a C. platanifolia e C. pentandra são exigentes por luz em fase inicial de crescimento, crescem rápido e persistem sobre o dossel ou como árvores emergentes nas florestas maduras. Estas espécies apresentam fecundação cruzada abaixo de $80 \%$ e ocorrem em baixa densidade de adultos com poucos ou nenhum indivíduo presente nas florestas primárias. Segundo os autores, sistemas de cruzamentos mistos podem ser esperados às espécies destes grupos de plantas por regenerarem em ambientes raros, como as clareiras. 


\section{SISTEMA DE CRUZAMENTO DE DUAS ESPÉCIES PIONEIRAS DA FLORESTA TROPICAL: Trema micrantha (L.) B. e Cecropia pachystachya Trec., AVALIADOS EM FRAGMENTOS FLORESTAIS}

\section{Resumo}

A utilização dos princípios genéticos no manejo e conservação de espécies da floresta tropical requer detalhado conhecimento do modo de reprodução, sistema de cruzamento e estrutura genética nas populações das espécies de interesse. Trema micrantha é uma das primeiras espécies a se estabelecer em áreas em início de sucessão, e Cecropia pachystachya é espécie pioneira dióica e seletivamente higrófita. Ambas espécies são polinizadas pelo vento e produzem muitas sementes que são dispersas por animais. Os sistemas de cruzamento destas espécies foram avaliados com base em 24 progênies com 10 indivíduos, obtidas de populações localizadas em dois fragmentos da Floresta Tropical Semidecidual, no Estado de São Paulo. Os parâmetros de sistema de cruzamento foram estimados a partir de locos isoenzimáticos polimórficos, somando-se sete locos com 17 alelos para C. pachystachya e 13 locos com 30 alelos para $T$. micrantha. Os resultados indicaram que T. micrantha apresenta sistema de cruzamento misto, com preferência por alogamia ( $\hat{t}_{m}$ de 0,966 e 0,819$)$, que suas populações estão sujeitas a variações nas proporções de endogamia ( $\hat{F}$ de $-0,022$ e 0,103$)$ e a altas taxas de cruzamentos biparentais ( $\hat{r}_{p}$ de 0,653 e 0,605 ). As estimativas de cruzamento obtidas para $C$. pachystachya não corresponderam às expectativas para espécies dióicas $\left(\hat{t}_{m}\right.$ de 0,816 e 0,794). Verificou-se significativa proporção de cruzamentos entre indivíduos aparentados $\left(t_{m}-t_{s}\right.$ de 0,072 e 0,128$)$, indicando estruturação espacial dos indivíduos sob condições naturais da espécie. As estimativas revelaram que a grande maioria das 
progênies de C. pachystachya são compostas por irmãos completos ( $\hat{r}_{p}$ de 0,868 e 0,990) resultantes de cruzamentos biparentais.

\section{Summary}

[Mating system of two pioneer tree species of the tropical forest: Trema micrantha (L.)B. and Cecropia pachystachya Tre.]

The utilization of genetics in the management and conservation of tropical forest species requires detailed knowledge of the mating system and genetic structure in the populations of the species of interest. Trema micrantha is one of the first species to be established in abandoned areas and Cecropia pachystachya is a pioneer dioecious tree and selectively adapted to wet soils. Both species are pollinated by wind and produce seeds that are dispersed by animals. The mating systems of these species were evaluated in two fragments from the decidual tropical forest, in the State of São Paulo. Ten seeds per plant and 24 plants per population were germinated to generate progeny arrays used in the analyses. The mating system parameters were estimated from seven polymorphic isozymatic loci with 17 alleles for C. pachystachya and 13 loci with 30 alleles for $T$. micrantha. The results indicated that $T$. micrantha presents a mixed mating system, with preference to outcrossing ( $\hat{t}_{m}=0.966$ and 0.819 , in both fragments), that it is subject to variations in the frequency of inbreeding ( $\hat{F}=-0.022$ and -0.103 , for both fragments) and to high rates of biparental mating ( $\hat{r}_{p}=0.653$ and 0.605 ). The estimates obtain for C. pachystachya did not correspond to the expectations of a dioecious species $\left(\hat{t}_{m}=\right.$ 0.816 and 0.794 in both fragments). A significant proportion of related individuals were observed ( $\hat{t} m-\hat{t} s=0.072$ and 0.128 , both fragments), indicating a spacial structure of individuals under the species natural condition. The estimates showed that the great majority of $C$. pachystachya progenies are composed of full-sib matings $\left(\hat{r}_{p}=0.868\right.$ and 0.990 in both fragments), resulting from biparental matings. 


\subsection{Introdução}

As florestas tropicais possuem uma grande diversidade de espécies arbóreas com diferentes sistemas reprodutivos, associados às complexas interações com agentes polinizadores e dispersores de sementes. Para a maioria destas espécies arbóreas, podese considerar que elas ocorrem em baixas densidades, que dependem de animais para a dispersão de pólen e/ou sementes e que realizam fecundação cruzada, sendo predominantemente alógamas (Bawa, 1974). Assim, admite-se que as espécies arbóreas tropicais possuem um modo complexo e variado de reprodução.

Para se pensar o manejo e a conservação de espécies arbóreas, é fundamental se ter conhecimento sobre o modo de reprodução, o sistema de cruzamento e a estrutura genética nas populações das espécies de interesse. A ocorrência de endogamia, por exemplo, não depende apenas das características genéticas do indivíduo, mas também da configuração espacial dos seus aparentados (Bawa \& Krugman, 1991).

O sistema de cruzamento é fundamental na determinação da composição genética das populações. Ele regula a distribuição da diversidade genética entre e dentro de progênies, populações e subdivisões de uma população (Hamrick, 1982). Assim, o sistema de cruzamento determina a associação entre as progênies e o grau de parentesco entre os descendentes que compõem tais progênies, bem como afeta a heterogeneidade genética espacial existente dentro e entre populações naturais. Ele é determinado pela taxa de auto fecundação, cruzamentos correlacionados, padrão de distribuição de indivíduos parentes (estrutura de família) e pelas características do fluxo gênico da espécie. O florescimento das plantas e movimentação de grãos de pólen e sementes entre e dentro das populações caracteriza o fluxo gênico. O fluxo gênico restrito define a variação das populações em resposta à seleção natural local ou deriva genética, enquanto fluxo gênico sobre longa distâncias promove homgeneidade genética entre as populações da espécie (Slatkin, 1985; Ellstrand, 1992).

Uma das principais mudanças causadas pelo homem é a fragmentação e degradação de florestas contínuas (Saunders et al. 1991). As drásticas mudanças na geometria da paisagem tendem a afetar as interações entre plantas e animais e, 
consequentemente, a demografia e recrutamento de plantas (Janzen, 1983; Howe, 1984). A fragmentação pode afetar a densidade populacional de animais, a amplitude de flutuação das suas populações, as atividades dos polinizadores e o arranjo de forrageamento dos mesmos (Shaffer, 1981; Pulliam, 1988), atingindo potencialmente a polinização e o nível de produção de sementes nas plantas (Jennersten, 1988; Menges, 1991).

Da mesma forma, a reprodução das plantas pode ser afetada pelas mudanças no microclima, em resposta às alterações do vento, da insolação e da dessecação (Saunders et al. 1991). Dessa forma, as conseqüências genéticas da fragmentação são alterações no fluxo gênico original, refletindo diretamente na taxa de cruzamento por alterar o tamanho das populações das espécies, ou indiretamente, por influenciar a abundância ou comportamento dos agentes polinizadores (Karron et al. 1995). Portanto, tais conseqüências tendem aumentar a freqüência de cruzamentos endogâmicos nas populações remanescentes. O aumento da endogamia ou homozigosidade pode resultar em depressão endogâmica, sendo esta mais severa em espécies predominantemente alógamas que mantêm altos níveis de carga genética (Nason \& Hamrick, 1997).

Para as espécies pioneiras ou populações de plantas colonizadoras, a possibilidade de reprodução pode ser vista como um desafio durante o processo de ocupação de novas áreas (Baker, 1955). Neste aspecto, associado à ocorrência de gargalo genético (bottleneck) variando com o tamanho da população colonizadora, o sistema de cruzamento apresenta um papel fundamental na sobrevivência das novas populações. Ele afeta profundamente a diversidade genética e a estrutura das populações colonizadores e está associado à capacidade de resposta à pressão de seleção local (Hamrick et al. 1979).

Segundo Clegg (1980), uma forma eficiente de se estimar a taxa de cruzamento ou de autofecundação é analisar o sistema de cruzamento de um conjunto de progênies por meio de marcadores genéticos. Essa conjunto de informações pode ser utilizado para elucidar as variações locais dos parâmetros do sistema de cruzamento, conseqüentes de fatores ambientais e diferenças entre populações marginais e centrais, indicando mudanças microevolutivas seguindo o efeito fundador (Sun \& Ritland, 1998). Da mesma 
forma, possibilita estudar os efeitos da fragmentação ou antropização quando se compara populações localizadas em florestas consideradas intactas com florestas fragmentadas.

Diante do exposto, o principal objetivo deste estudo é estimar os parâmetros do sistema de cruzamento de duas espécies pioneiras arbóreas: Trema micrantha e Cecropia pachystachya, a partir das freqüências gênicas e genotípicas de progênies de duas populações de cada espécie. As populações foram amostradas em fragmentos bem distintos quanto ao estado de conservação e área florestal total permitindo que os resultados sejam discutidos quanto aos efeitos da fragmentação sobre o sistema de cruzamento destas espécies.

\subsection{Material e métodos}

\subsubsection{Caracterização das espécies}

Progênies foram amostradas de populações das espécies Cecropia pachystachya Trec. e Trema micrantha (L.) B.. C. pachystachya é planta dióica que pode atingir 4 a 7 m de altura e 15 a 25 cm de diâmetro. É espécie pioneira e seletiva higrófita, ocorrendo em várias formações florestais no Brasil, desde o Ceará até Santa Catarina. Possui ocorrência rara no interior da mata primária densa, é mais comum em matas secundárias e também em capoeiras novas situadas junto às vertentes ou cursos d'água. Sua polinização é pelo vento e produz uma grande quantidade de sementes que são dispersas por ampla diversidade de pássaros e por morcegos (Lorenzi, 1992).

T. micrantha ocorre em vários tipos de ambientes, exceto nos mais úmidos. É uma das primeiras espécies a se estabelecer em áreas abandonadas, continuando a existir nos estágios da sucessão secundária, exceto na floresta clímax (Lorenzi, 1992). Esta espécie ocorre entre as latitudes $30^{\circ} \mathrm{N}$ (Estados Unidos) e $30^{\circ} \mathrm{S}$ (Brasil) e é classificada como hermafrodita críptica por possuir plantas variando de monóicas a dióicas (Torres, 1996). Suas flores são unissexuais ou bissexuais andrógenas e a dispersão das sementes 
é realizada por aves e outros animais (Carvalho, 1994). A espécie é polinizada principalmente pelo vento, mas pode ser visitada por pequenos insetos (Bawa et al. 1985a).

\subsection{2 Áreas de estudo}

As populações estudadas foram amostradas na Estação Ecológica dos Caetetus (EEC) e na Reserva Florestal de Santa Genebra (RMSG). A EEC é administrada pelo Instituto Florestal de São Paulo e está situada entre a latitude $22^{\circ} 22^{\prime}$ a $22^{\circ} 27^{\prime} \mathrm{S}$ e longitude $49^{\circ} 40^{\prime}$ e $49^{\circ} 43^{\prime}$ O, entre os municípios de Gália e Alvilândia-SP. Ela compreende uma área de 2.179 ha de floresta tropical latifoliada semidecídua, com características primárias. Nela, encontram-se árvores com alturas de até $30 \mathrm{~m}$ e diâmetros de $1 \mathrm{~m}$. Sobretudo, a flora local é considerada praticamente intacta, representando um dos maiores e mais conservados remanescentes deste tipo de floresta em todo o Estado de São Paulo (Perecin, 2000). A EEC está inserida em uma paisagem de intensa exploração agrícola (principalmente café e laranja) e pecuária.

A RMSG possui 251,8 ha de floresta tropical estacional semidecídua (IBGE, 1993) e está localizada nas coordenadas $22^{\circ} 49^{\prime} 45^{\prime}$ ' S e $47^{\circ} 06^{\prime} 33^{\prime}$ ' W, no Município de Campinas - SP. Ao longo de sua área levemente ondulada, com altitudes variando de 580 a 610 m, verifica-se um mosaico de vegetação, em que várias fases sucessionais são encontradas. Ocorrem tanto áreas com floresta preservada, formando um dossel contínuo de 15 a 18 metros de altura, com espécies emergentes de até 25 m, como áreas muito perturbadas ocupadas por espécies de estágio sucessional inicial. Além destas, encontram-se áreas mais baixas com solos encharcados ocupados por uma Floresta Paludosa. Encontrando-se numa paisagem urbanizada, neste fragmento, além dos processos naturais e os efeitos de borda, ocorreram perturbações antrópicas como queimada, extração seletiva de madeira e corte raso de alguns pequenos trechos para utilização da lenha (Leitão-Filho, 1995). 


\subsubsection{Amostragem}

Para coleta das sementes realizou-se visitas à campo, ao longo dos meses de janeiro a junho de 2001, para ensacamento de ramos e garantia da permanência de frutos maduros nas plantas de T. micrantha e para acompanhar o amadurecimento das infrutescências de C. pachystachya. As coletas foram realizadas individualmente por árvore e o material foi levado ao laboratório de sementes de espécies florestais do Depto. de Ciências Florestais, ESALQ-USP. As sementes de T. micrantha receberam tratamento para acelerar a germinação, sendo mantidas em ácido sulfúrico concentrado por 20 minutos e lavadas em água corrente por outros 10 (Torres, 1996). Posteriormente, foram novamente lavadas com hipoclorito comercial a 0,2\%, antes de seguir para as caixas de gerbox.

As sementes de ambas espécies foram submetidas às mesmas condições de fototropismo, com 8 horas de escuro e 16 de luz, e à temperatura alternada de $30^{\circ} \mathrm{C}$ sob luz e $20^{\circ} \mathrm{C}$, quando em escuro. Ambas espécies apresentaram alta taxa de germinação (> 85\%) mas com grande variação entre as progênies de T. micrantha. As plântulas foram repicadas e aclimatadas no laboratório, até serem transferidas para casa de vegetação.

Somaram-se 24 progênies para ambas espécies, sendo 10 plântulas de cada progênie submetidas às análises de isoenzimas. Das progênies de C. pachystachya, 14 se originaram de plantas da EEC enquanto o restante foi coletado de plantas compondo um grande grupo de indivíduos localizados às margens da Rodovia Geraldo de Barros (SP 191, próximo ao km 265), no Município de São Manuel - S.P., a 146 quilômetros daquele fragmento. Das progênies de T. micrantha, 9 foram coletadas da população da RMSG e as outras 15, da EEC.

\subsubsection{Protocolos}

Previamente à aplicação da técnica eletroforese de isoenzimas, testou-se quatro sistemas tampão gel/eletrodo com 32 sistemas enzimáticos. Durante a extração, utilizouse o tampão 1, citado em Alfenas et al. (1991). Os procedimentos posteriores seguiram 
as recomendações descritas pelos mesmos autores. Feita a seleção, as enzimas extraídas das folhas jovens das mudas de $T$. micrantha foram submetidas à eletroforese e à revelação para glucose desidrogenase (GDH, EC-1.1.1.47), xiquimato desidrogease (SKDH, EC-1.1.1.25), fosfatase ácida (ACP, EC-3.1.3.2), isocitrato desidrogenase (IDH, EC-1.1.1.42), malato desidrogenase (MDH, EC-1.1.1.37), diaforase (DIA, EC-1.8.1.4), glutamato oxaloacetato transaminase (GOT, EC-2.6.1.1), glucose-6-fosfato desidrogenase (G6PDH, EC-1.1.1.49) e esterase (EST, EC-3.1.1.1). Deste processo, obtive-se os zimogramas dos quais foram interpretados 13 locos polimórficos, somandose 30 alelos.

Das folhas jovens de C. pachystachya, foram reveladas as enzimas fosfogluco isomerase (PGI, EC-5.3.1.8), fosfatase ácida (ACP, EC-3.1.3.2), fosfoglucomutase (PGM, EC-5.4.2.2), isocitrato desidrogenase (IDH, EC-1.1.1.42), xiquimato desidrogease (SKDH, EC-1.1.1.25) e glucose-6-fosfato desidrogenase (G6PDH, EC1.1.1.49). Da interpretação destes zimogramas somou-se sete locos isoenzimáticos polimórficos e um total de 17 alelos.

Durante a eletroforese, as enzimas GDH, SKDH, ACP IDH e MDH de $T$. micrantha e a PGI, ACP e PGM de C. pachystachya apresentaram melhor padrão de revelação e resolução, sob o sistema tampão gel/eletrodo desenvolvido por Clayton e Tretiak (1972), que é citado com algumas modificações (sistema 8), em Alfenas et al. (1991). Para as outras enzimas, optou-se pelo sistema tampão gel/eletrodo desenvolvido por Hakim-Elahi (1980), citado em Alfenas et al. (1991) (sistema 25).

\subsubsection{Análise dos dados}

Para inferir sobre o sistema de cruzamento, com base nas freqüências genotípicas obtidas da análise isoenzimática, utilizou-se o programa MLTR (Multilocus Mating System Program, versão 1.1, revisado em novembro de 1996) desenvolvido por Ritland (1994). O programa permite obter estimativas sobre: taxa de fecundação cruzada baseada em múltiplos locos $\left(t_{m}\right)$; taxa de fecundação cruzada para cada loco individualmente e a média das estimativas para a população $\left(t_{s}\right)$; coeficiente de 
endogamia de Wright $(F)$; correlação entre pares de sementes quanto ao cruzamento $\left(r_{t}\right)$, correspondente à taxa de cruzamento dentro de progênies; correlação entre grãos de pólen dos pares de sementes de fecundação cruzada $\left(r_{p}\right)$, inferindo-se sobre a origem dos grãos de pólen. Além das estimativas dos parâmetros citados, o programa também calcula as freqüências alélicas no conjunto de pólen $(p)$ e nos óvulos (o) e determina os genótipos maternos. A rotina do programa desenvolvida para se estimar os parâmetros do sistema de cruzamento foi descrita por Ritland \& Jain (1981); outros detalhes sobre a estimativa dos genótipos maternos e da freqüência gênica no conjunto de pólen podem ser encontrados em Brown e Allard (1970) e em Ritland (1983), respectivamente.

Todas as estimações desenvolvem-se com base nas freqüências gênicas obtidas das progênies analisadas. A partir destas freqüências, pode-se inferir sobre os genótipos das árvores matrizes, do grupo de pólen (p), taxa de cruzamento (t) e o coeficiente de endogamia de Wright (F). Todos estes parâmetros são utilizados simultaneamente durante a rotina de estimação através da solução de equações de probabilidade, envolvendo o método de Newton-Ranphson. A descrição do processo de estimação de máxima verossimilhança das estimativas dos parâmetros do sistema de cruzamento são apresentados por Ritland e El-Kassaby (1985).

Os parâmetros do modelo de cruzamentos correlacionados $\left(r_{t}\right.$ e $\left.r_{p}\right)$ são estimadores da taxa de autofecundação e fecundação cruzada dentro de progênies, considerando a origem dos gametas. O método para se obter estas estimativas, conhecido como modelo de pares de progênies, baseia-se em repetidas amostragens de pares de sementes das progênies dentro de população, seguida pela comparação entre os genótipos das duas sementes amostradas (Ritland, 1989). Desta forma, em cada repetição, pode-se inferir sobre a origem do pólen para aquele par de genótipos, podendo ser ambas formadas por autofecundação, uma por autofecundação e outra por fecundação cruzada, ou ambas por fecundação cruzada, sendo que, neste último, os grãos de pólen podem ter sido originados de apenas uma única árvore ou de diferentes árvores.

O modelo assume que as plântulas resultam de um mistura de cruzamentos aleatórios e autofecundações, sendo considerado que o conjunto de pólen é distribuído 
de forma homogênea para o cruzamento com todos os genótipos maternos, que os alelos de diferentes locos segregam independentemente, que os locos não são afetados pela seleção ou mutação entre o tempo de cruzamento e análise, e que os locos estão em equilíbrio de Hardy-Weinberg ou que a segregação dos alelos em plantas maternas heterozigotas é estritamente mendeliana, em uma razão de 1:1 tanto para produção de pólen como de óvulo (Ritland \& Jain, 1981). Para se testar a hipótese de que as populações estão em EHW, comparou-se as freqüências genotípicas observadas em relação às freqüências genotípicas esperadas segundo o modelo de Equilíbrio de HardyWeinberg, avaliando se os desvios existentes são ou não significativamente diferentes de zero. Para tanto, utilizou-se o teste Exato de Fisher. Este teste exige computação intensa e recorre ao agrupamento de genótipos, quando se refere a locos com mais de dois alelos. A análise foi desenvolvida com auxílio do programa TFPGA disponibilizado por Miller (1997), quando foram utilizadas dez baterias de análises, com 1.000 permutações cada, num total de 10.000 permutações. Também aplicou-se o teste qui-quadrado para testar a homogeneidade (independência) das freqüências alélicas de pólen e óvulos sobre as populações das espécies e respectivas populações.

\subsection{Resultados}

\subsubsection{Teste de Equilíbrio de Hardy-Weinberg}

Com base nos resultados encontrados no teste Exato de Fisher, para verificar desvios das freqüências genotípicas observadas das esperadas pelo modelo de EHW, verifica-se que poucos locos não apresentaram distribuição ao acaso das freqüências gênicas. Apenas os locos Skdh, Idh, Mdh-2 e mdh-1, na população de T. micrantha amostrada na RMSG, e os locos Skdh, Acp-2 e Est, da população da EEC, não apresentaram distribuições esperadas segundo as proporções de EHW ao nível de significância de 5\% (Tabela 1). 
Para a espécie C. pachystachya, apenas os locos Pgm-1 e Pgm-2 da população EEC não aderiram às proporções de EHW. Desvios do EHW podem ser causados pelo sistema de reprodução ou por fatores evolutivos como seleção, migração, mutação ou deriva genética (Ritland \& Jain, 1981). Para se separar os efeitos reprodutivos dos fatores evolutivos seria necessário aplicar o teste de Equilíbrio de Wright (EEW). No entanto, este teste só é realizado em locos que possuem, no mínimo, três alelos. Portanto, como apenas o loco Skdh de T. micrantha permitiria a aplicação do teste, este foi inviabilizado.

Tabela 1. Probabilidades obtidas nos testes de aderência às proporções de HardyWeinberg, para os locos polimórficos analisados nas progênies de Trema micrantha e Cecropia pachystachya, utilizando-se o teste Exato de Fisher.

\begin{tabular}{|c|c|c|c|c|c|}
\hline \multicolumn{3}{|c|}{ Trema micrantha } & \multicolumn{3}{|c|}{ Cecropia pachystachya } \\
\hline Locos & RMSG & EEC & Locos & RMSG & EEC \\
\hline Gdh & 0,247 & -------- & Pgi-3 & 1,000 & 0,404 \\
\hline Skdh & $0,004 * *$ & $0,000^{* *}$ & Аср-2 & 0,144 & 1,000 \\
\hline Аср-3 & 0,249 & 0,252 & Pgm-1 & 0,410 & $0,006^{* *}$ \\
\hline Аср-2 & 0,231 & $0,016^{*}$ & Pgm-2 & 1,000 & $0,002 * *$ \\
\hline Аср-1 & 0,464 & 0,228 & Idh-1 & 1,000 & 0,841 \\
\hline Idh & $0,014^{*}$ & 0,076 & Skdh & 1,000 & ------- \\
\hline Est & 0,567 & $0,000 * *$ & G6pdh & 0,751 & 0,579 \\
\hline Mdh-2 & $0,019 *$ & 1,000 & & & \\
\hline Mdh-3 & ------- & 1,000 & & & \\
\hline Mdh-1 & $0,042 *$ & 0,286 & & & \\
\hline Dia-2 & 0,433 & 0,453 & & & \\
\hline Got & 0,110 & 0,175 & & & \\
\hline G6pdh & 1,000 & 0,153 & & & \\
\hline
\end{tabular}

\subsubsection{Homogeneidade nas freqüências alélicas dos óvulos e pólen}

De acordo com os resultados do teste de homogeneidade das freqüências alélicas dos óvulos e pólens para ambas espécies e populações (Tabelas 2 e 3), 50\% dos locos apresentaram homogeneidade nas frqüências alélicas, nas populações de T. micrantha. 
Tabela 2. Divergência genética entre freqüências alélicas dos óvulos e pólen em populações de Trema micrantha e probabilidades pelo teste qui-quadrado.

\begin{tabular}{|c|c|c|c|c|c|c|c|}
\hline \multirow[b]{2}{*}{ Loco } & \multirow[b]{2}{*}{ Alelo } & \multicolumn{3}{|c|}{ População EEC } & \multicolumn{3}{|c|}{ População RMSG } \\
\hline & & Pólen & Óvulo & $\mathbf{P}$ & Pólen & Óvulo & $P$ \\
\hline \multirow[t]{2}{*}{ Gdh } & 1 & $0,993(0,000)$ & $0,968(0,000)$ & & $0,922(0,038)$ & $0,889(0,063)$ & \\
\hline & 2 & $0,007(0,000)$ & $0,032(0,000)$ & 0,201 & $0,078(0,038)$ & $0,111(0,063)$ & 0,425 \\
\hline \multirow[t]{3}{*}{ Skdh } & 1 & $0,511(0,076)$ & $0,452(0,085)$ & & $0,900(0,096)$ & $0,722(0,067)$ & \\
\hline & 2 & $0,415(0,075)$ & $0,516(0,085)$ & & $0,100(0,096)$ & $0,278(0,067)$ & \\
\hline & 3 & $0,073(0,025)$ & $0,032(0,000)$ & 0,217 & ---- & --- & $0,001 * *$ \\
\hline \multirow[t]{3}{*}{ Аср-3 } & 1 & $0,053(0,023)$ & $0,100(0,043)$ & & $0,094(0,030)$ & $0,056(0,023)$ & \\
\hline & 2 & $0,531(0,056)$ & $0,800(0,053)$ & & $0,631(0,133)$ & $0,611(0,065)$ & \\
\hline & 3 & $0,416(0,051)$ & $0,100(0,045)$ & $0,000 * *$ & $0,275(0,138)$ & $0,333(0,067)$ & 0,461 \\
\hline \multirow[t]{2}{*}{ Aср-2 } & 1 & $0,159(0,035)$ & $0,533(0,063)$ & & $0,666(0,204)$ & $0,500(0,000)$ & \\
\hline & 2 & $0,841(0,035)$ & $0,467(0,063)$ & $0,000 * *$ & $0,334(0,204)$ & $0,500(0,000)$ & $0,017 *$ \\
\hline \multirow[t]{2}{*}{ Aср-1 } & 1 & $0,398(0,095)$ & $0,167(0,083)$ & & $0,094(0,047)$ & $0,222(0,151)$ & \\
\hline & 2 & $0,602(0,095)$ & $0,833(0,083)$ & $0,000 * *$ & $0,906(0,047)$ & $0,778(0,151)$ & $0,013^{*}$ \\
\hline \multirow[t]{2}{*}{ Idh } & 1 & $0,271(0,045)$ & $0,200(0,059)$ & & $0,100(0,045)$ & $0,222(0,058)$ & \\
\hline & 2 & $0,729(0,045)$ & $0,800(0,059)$ & 0,237 & $0,900(0,045)$ & $0,778(0,058)$ & $0,019 *$ \\
\hline \multirow[t]{2}{*}{ Est } & 1 & $0,767(0,053)$ & $0,767(0,066)$ & & $0,834(0,145)$ & $0,500(0,028)$ & \\
\hline & 2 & $0,233(0,053)$ & $0,233(0,066)$ & 1,000 & $0,166(0,145)$ & $0,500(0,028)$ & $0,000 * *$ \\
\hline \multirow[t]{3}{*}{ Mdh-2 } & 1 & $0,985(0,008)$ & $0,967(0,022)$ & & $0,840(0,056)$ & $0,778(0,072)$ & \\
\hline & 2 & $0,015(0,008)$ & $0,033(0,022)$ & & $0,084(0,030)$ & $0,167(0,069)$ & \\
\hline & 3 & ---- & ---- & 0,406 & $0,077(0,031)$ & $0,056(0,061)$ & 0,191 \\
\hline \multirow[t]{2}{*}{ Mdh-3 } & 1 & $0,007(0,004)$ & $0,032(0,000)$ & & $0,077(0,039)$ & $0,053(0,003)$ & \\
\hline & 2 & $0,993(0,004)$ & $0,968(0,000)$ & 0,201 & $0,923(0,039)$ & $0,947(0,003)$ & 0,491 \\
\hline \multirow[t]{2}{*}{ Mdh-1 } & 1 & $0,172(0,060)$ & $0,167(0,080)$ & & $0,250(0,086)$ & $0,444(0,136)$ & \\
\hline & 2 & $0,828(0,060)$ & $0,833(0,080)$ & 0,929 & $0,750(0,086)$ & $0,556(0,136)$ & $0,004 * *$ \\
\hline \multirow[t]{3}{*}{ Dia-2 } & 1 & $0,177(0,073)$ & $0,167(0,075)$ & & $0,133(0,184)$ & $0,316(0,089)$ & \\
\hline & 2 & $0,792(0,073)$ & $0,800(0,092)$ & & $0,534(0,224)$ & $0,632(0,090)$ & \\
\hline & 3 & $0,031(0,017)$ & $0,033(0,027)$ & 0,980 & $0,332(0,149)$ & $0,053(0,003)$ & $0,000 * *$ \\
\hline \multirow[t]{3}{*}{ Got } & 1 & $0,061(0,042)$ & $0,133(0,052)$ & & $0,250(0,107)$ & $0,056(0,048)$ & \\
\hline & 2 & $0,402(0,066)$ & $0,467(0,124)$ & & $0,562(0,173)$ & $0,556(0,099)$ & \\
\hline & 3 & $0,537(0,049)$ & $0,400(0,107)$ & 0,076 & $0,188(0,158)$ & $0,380(0,066)$ & $0,000 * *$ \\
\hline \multirow[t]{2}{*}{ G6pdh } & 1 & $0,186(0,062)$ & $0,367(0,093)$ & & $0,167(0,064)$ & $0,500(0,021)$ & \\
\hline & 2 & $0,814(0,062)$ & $0,633(0,093)$ & $0,004 * *$ & $0,833(0,064)$ & $0,500(0,021)$ & $0,000 * *$ \\
\hline
\end{tabular}

( ) Desvio Padrão obtido por 1.000 reamostragem (bootstrap) sobre progênies

* Diferença significativa entre as freqüências alélicas à 95\% de probabilidade

** Diferença significativa entre as freqüências alélicas à 99\% de probabilidade 
Os locos Skdh, Idh, Est, Mdh-1, Dia-2 e Got indicaram distribuição homogênea das freqüências alélicas apenas na população de EEC, enquanto o loco Acp-3 teve este comportamento para a população da RMSG. Para esta espécie a população da EEC mostrou maior homogeneidade na distribuição de pólen. Em C. pachystachya os locos Pgi-3 e Pgm-1 apresentaram diferenças nas freqüências gênicas de pólen e do óvulo apenas na população EEC, enquanto o loco Acp-2 e Pgm-2 apresentaram apenas para a população RMSG. Os locos Skdh e G6pdh apresentaram diferenças em ambas populações (Tabela 3).

Diferenças nas freqüências gênicas do pólen e do óvulo indicam desvios de cruzamentos aleatórios, sendo que a causa pode estar associada a diferentes fatores. Para as espécies em questão, as diferenças nas funções masculinas e femininas das plantas e a amostragem não representativa das plantas maternas são justificativas plausíveis. Ambas espécies apresentam floração distribuída por um longo período de tempo, o que caracteriza que determinadas árvores troquem gametas entre si, enquanto outras já estão em plena frutificação, ainda não atingiram a maturidade das suas flores, ou mesmo, não estão reproduzindo no ano em questão. Como uma segunda justificativa, $C$. pachystachya é espécie dióica e T. micrantha possui a grande maioria de suas flores monossexuadas. Dessa forma, aumenta-se as chances de muitas árvores não serem amostradas no conjunto de pólen e óvulos representantes das populações compostas por grande número de indivíduos.

O número de 24 progênies para cada espécie e sete e 13 locos polimórficos são satisfatórios na obtenção das estimativas dos parâmetros do sistema de cruzamento, o que reduziriam os possíveis efeitos da violação da pressuposição de homogeneidade das freqüências alélicas dos óvulos e do pólen sobre tais estimativas (Ritland \& Jain, 1981).

A partir dos resultados obtidos para T. micrantha, a população amostrada na EEC apresenta distribuição de alelos mais homogênea, o que também pode estar refletindo os efeitos da fragmentação de contínuos florestais sobre a população da espécie. Por outro lado, a maior proporção de locos com significância para homogeneidade na distribuição de pólen na RMSG pode estar refletindo a entrada de grãos de pólen de indivíduos localizados próximos da população estudada. Este fragmento se encontra em uma 
paisagem que permite maior eficiência do vento no transporte de pólen por maiores distâncias.

Tabela 3. Divergência genética entre freqüências alélicas dos óvulos e pólen em populações de Cecropia pachystachya e probabilidades pelo teste quiquadrado.

\begin{tabular}{|c|c|c|c|c|c|c|c|}
\hline \multirow[b]{2}{*}{ Loco } & \multirow[b]{2}{*}{ Alelo } & \multicolumn{3}{|c|}{ População EEC } & \multicolumn{3}{|c|}{ População RMSG } \\
\hline & & Pólen & Óvulo & $\mathbf{P}$ & Pólen & Óvulo & $P$ \\
\hline \multirow[t]{3}{*}{ Pgi-3 } & 1 & $0,056(0,049)$ & $0,071(0,044)$ & & $0,199(0,097)$ & $0,167(0,081)$ & \\
\hline & 2 & $0,872(0,060)$ & $0,607(0,046)$ & & $0,801(0,097)$ & $0,833(0,081)$ & \\
\hline & 3 & $0,073(0,046)$ & $0,321(0,058)$ & $0,000 * *$ & --- & ---- & 0,558 \\
\hline \multirow[t]{2}{*}{ Аср-2 } & 1 & $0,138(0,069)$ & $0,179(0,068)$ & & $0,498(0,209)$ & $0,333(0,079)$ & \\
\hline & 2 & $0,862(0,069)$ & $0,821(0,068)$ & 0,427 & $0,502(0,209)$ & $0,667(0,079)$ & 0,018* \\
\hline \multirow[t]{2}{*}{ Pgm-1 } & 1 & $0,584(0,167)$ & $0,750(0,068)$ & & $0,500(0,201)$ & $0,500(0,000)$ & \\
\hline & 2 & $0,416(0,167)$ & $0,250(0,068)$ & 0,013* & $0,500(0,201)$ & $0,500(0,000)$ & 1,000 \\
\hline \multirow[t]{2}{*}{ Pgm-2 } & 1 & $0,751(0,094)$ & $0,786(0,063)$ & & $0,857(0,040)$ & $0,667(0,106)$ & \\
\hline & 2 & $0,249(0,094)$ & $0,214(0,063)$ & 0,557 & $0,143(0,040)$ & $0,333(0,106)$ & $0,002 * *$ \\
\hline \multirow[t]{3}{*}{ Idh-1 } & 1 & $0,380(0,181)$ & $0,393(0,074)$ & & $0,232(0,072)$ & $0,333(0,072)$ & \\
\hline & 2 & $0,238(0,156)$ & $0,536(0,075)$ & & $0,684(0,070)$ & $0,500(0,070)$ & \\
\hline & 3 & $0,382(0,145)$ & $0,071(0,041)$ & $0,000 * *$ & $0,084(0,071)$ & $0,167(0,071)$ & $0,025^{*}$ \\
\hline \multirow[t]{2}{*}{ Skdh } & 1 & $0,026(0,008)$ & $0,034(0,000)$ & & $0,100(0,065)$ & $0,111(0,065)$ & \\
\hline & 2 & $0,974(0,008)$ & $0,966(0,000)$ & 0,740 & $0,900(0,065)$ & $0,889(0,065)$ & 0,800 \\
\hline \multirow[t]{3}{*}{ G6pdh } & 1 & $0,364(0,161)$ & $0,071(0,043)$ & & $0,367(0,000)$ & $0,053(0,000)$ & \\
\hline & 2 & $0,127(0,107)$ & $0,857(0,054)$ & & $0,449(0,072)$ & $0,684(0,072)$ & \\
\hline & 3 & $0,509(0,217)$ & $0,071(0,037)$ & $0,000 * *$ & $0,184(0,072)$ & $0,263(0,072)$ & $0,000 * *$ \\
\hline
\end{tabular}

( ) Desvio Padrão obtido por 1.000 reamostragem (bootstrap) sobre progênies

* Diferença significativa entre as freqüências alélicas à 95\% de probabilidade

** Diferença significativa entre as freqüências alélicas à $99 \%$ de probabilidade 


\subsubsection{Sistemas de cruzamentos}

As estimativ-as dos parâmetros do sistema de cruzamento para as espécies $T$. micrantha e C. pachystachya são apresentadas individualmente para as populações amostradas na RMSG e EEC (Tabela 4). T. micrantha apresentou elevadas taxas de fecundação cruzada multilocos e, com base no desvio padrão, revelou diferença significativa entre as duas populações $(0,819$ e 0,966 para RMSG e EEC, respectivamente). Diante destas estimativas, T. micrantha possui sistema de cruzamento misto, com predomínio de fecundação cruzada. O índice de fixação estimado para população da RMSG foi positivo e elevado, podendo indicar endogamia nesta população ( $F$ de 0,103 e -0,022). No entanto, o desvio padrão obtido a partir de 1.000 reamostragens (bootstraps) sobre progênies, indicou grande variação nas estimativas. As diferenças entre as taxas de cruzamento multilocos e unilocos foram positivas e significativas $\left(\hat{t}_{m}-\hat{t}_{s}\right.$ de 0,106 e 0,151$)$, sugerindo que ocorrem cruzamentos entre aparentados e que as populações estão estruturadas espacialmente.

As estimativas de cruzamentos correlacionados variaram entre as populações, sendo significativamente diferente de zero nas progênies da população da RMSG ( $\hat{r}_{t}$ de 0,418 e -0,100 para RMSG e EEC, respectivamente). Ambas populações de $T$. micrantha apresentaram estimativas elevadas para $\hat{r}_{p}(0,605$ e 0,653$)$, indicando que a maior parte dos indivíduos nas progênies de fecundação cruzada são irmãos completos resultantes de cruzamentos biparentais.

C. pachystachya é espécie dióica, o que garante taxas de fecundação cruzada máximas. No entanto, as estimativas obtidas são significativamente diferentes de um, que é o valor esperado para espécies dióicas ( $t_{m}$ de 0,794 e 0,816$)$. As diferenças entre as taxas de fecundação cruzada multilocos e unilocos sugerem cruzamentos entre indivíduos aparentados ( $t_{m}-t_{s}$ de 0,072 e 0,128, para RMSG e EEC, respectivamente), indicando que a distribuição espacial dos indivíduos na população da EEC apresenta maior grau de estruturação em famílias. Ambas populações apresentam índice de fixação total próximo de zero ( $\hat{F}$ de $-0,019$ e $-0,020)$. 
Tabela 4. Estimativa de taxa de cruzamento unilocus $\left(\hat{t}_{s}\right)$, multilocos $\left(\hat{t}_{m}\right)$, entre aparentados $\left(\hat{t}_{m}-\hat{t}_{s}\right)$, correlação de cruzamentos $\left(\hat{r}_{t}\right)$, correlação de paternidade $\left(\hat{r}_{p}\right)$ e coeficiente de endogamia $(\hat{F})$ para ambas espécies estudadas, a partir de marcadores isoenzimáticos.

\begin{tabular}{ccccc}
\hline \multirow{2}{*}{$\begin{array}{c}\text { Espécies } \\
\text { Populações }\end{array}$} & RMSG & EEC & \multicolumn{2}{c}{ Cecropia pachystachya } \\
\hline$f$ & $0,103(0,104)$ & $-0,022(0,096)$ & $-0,019(0,403)$ & $-0,020(0,159)$ \\
$f$ & $0,819(0,095)$ & $0,966(0,027)$ & $0,794(0,211)$ & $0,816(0,072)$ \\
$t_{m}$ & $0,713(0,085)$ & $0,815(0,048)$ & $0,722(0,195)$ & $0,689(0,087)$ \\
$t_{S}$ & $0,106(0,029)$ & $0,151(0,036)$ & $0,072(0,050)$ & $0,128(0,038)$ \\
$t_{m}-t_{S}$ & $0,418(0,274)$ & $-0,100(0,463)$ & --- & -- \\
$r_{t}$ & $0,605(0,146)$ & $0,653(0,137)$ & $0,990(0,102)$ & $0,868(0,122)$ \\
$r_{p}$ & & & &
\end{tabular}

( ) Desvio padrão obtido pelo método de reamostragem bootstrap, utilizando-se 1.000 repetições sobre progênies

Sendo espécie dióica, não se considera a existência de progênies compostas por algum indivíduo resultante de autofecundação, sendo desprezado o parâmetro que avalia a correlação nos cruzamentos. Por outro lado, a correlação de paternidade apresentou estimativas muito elevadas ( $r_{p}$ de 0,990 e 0,868$)$, sugerindo que a grande maioria das progênies são compostas com indivíduos irmãos completos, resultantes de cruzamentos biparentais.

Taxas de fecundação cruzada foram obtidas para cada progênie de ambas espécies e estão apresentadas na Tabela 5. Verifica-se grande variação nas taxas de cruzamentos entre as árvores. Para T. micrantha, verifica-se $t_{m}$ variando de 0,20 a 1,48, na mesma população. Da mesma forma, as estimativas variaram entre 0,28 e 1,69 para C. pachystachya, estando 14 estimativas abaixo e quatro acima da unidade esperada para uma espécie dióica. Salienta-se que os valores 0,00 e 2,00 indicam não convergência dos dados ao modelo de cruzamento misto. 
Nas Tabelas 6 e 7, estão apresentadas as estimativas de índice de fixação e taxas de cruzamentos obtidas para locos independentes. Verifica-se estimativas negativas para índice de fixação em $C$. pachystachya e $T$. micrantha, sugerindo excesso de heterozigotos nos locos correspondentes. Somado à grande variação nas estimativas dos diferentes locos analisados, o erro padrão reflete a variação na ocorrência de cruzamentos nas progênies estudadas.

Tabela 5. Estimativas de taxa de fecundação cruzada por progênie de ambas espécies, amostradas na Reserva Florestal de Santa Genebra e na Estação Ecológica dos Caetetus.

\begin{tabular}{|c|c|c|c|c|c|c|c|}
\hline \multirow[b]{2}{*}{ Progênie } & \multicolumn{3}{|c|}{ Trema micrantha } & \multicolumn{4}{|c|}{ Cecropia pachystachya } \\
\hline & RMSG & & EC & & ISG & & EC \\
\hline F1 & $0,67 \quad(0,17)$ & 0,82 & $(0,46)$ & 0,00 & $(0,00)$ & 0,80 & $(0,43)$ \\
\hline F2 & $2,00 \quad(0,00)$ & 1,32 & $(0,33)$ & 0,43 & $(0,43)$ & 0,28 & $(0,29)$ \\
\hline F3 & $1,25 \quad(0,39)$ & 0,94 & $(0,54)$ & 2,00 & $(0,00)$ & 1,08 & $(0,46)$ \\
\hline F4 & $0,20 \quad(0,12)$ & 0,95 & $(0,55)$ & 0,68 & $(0,38)$ & 0,78 & $(0,33)$ \\
\hline F5 & $2,00 \quad(0,00)$ & 2,00 & $(0,00)$ & 0,45 & $(0,23)$ & 0,67 & $(0,28)$ \\
\hline F6 & $2,00 \quad(0,00)$ & 0,91 & $(0,43)$ & 0,00 & $(0,00)$ & 0,92 & $(0,59)$ \\
\hline F7 & $0,88 \quad(0,59)$ & 2,00 & $(0,00)$ & 0,78 & $(0,33)$ & 0,89 & $(0,34)$ \\
\hline F8 & $0,71 \quad(0,35)$ & 0,72 & $(0,27)$ & 2,00 & $(0,16)$ & 0,89 & $(0,32)$ \\
\hline F9 & $1,48 \quad(0,31)$ & 0,74 & $(0,37)$ & 1,18 & $(0,32)$ & 0,84 & $(0,27)$ \\
\hline F10 & & 1,09 & $(0,47)$ & & & 1,00 & $(0,27)$ \\
\hline F11 & & 0,90 & $(0,52)$ & & & 0,86 & $(0,29)$ \\
\hline F12 & & 0,85 & $(0,49)$ & & & 0,53 & $(0,15)$ \\
\hline F13 & & 2,00 & $(0,00)$ & & & 1,69 & $(0,22)$ \\
\hline F14 & & 0,82 & $(0,41)$ & & & 0,40 & $(0,24)$ \\
\hline F15 & & 2,00 & $(0,00)$ & & & & \\
\hline
\end{tabular}

( ) erro padrão obtido a partir de 100 bootstraps sobre locos 
Tabela 6. Estimativas de índice de fixação e taxa de fecundação cruzada por loco de Cecropia pachystachya, para as populações da Reserva Florestal de Santa Genebra e Estação Ecológica dos Caetetus.

\begin{tabular}{|c|c|c|c|c|c|}
\hline \multirow[t]{2}{*}{ Locos } & \multicolumn{2}{|c|}{ RMSG } & \multicolumn{3}{|c|}{ EEC } \\
\hline & $\hat{F}$ & $\hat{t}$ & & $\hat{F}$ & $\hat{t}$ \\
\hline Pgi-3 & $0,990 \quad(0,198)$ & $0,979 \quad(0,165)$ & $-0,080$ & $(0,447)$ & $0,540 \quad(0,195)$ \\
\hline Аср-2 & $-0,990 \quad(0,360)$ & $0,375 \quad(0,219)$ & $-0,673$ & $(0.704)$ & $0,966 \quad(0,329)$ \\
\hline Pgm-1 & $-0,556 \quad(0,291)$ & $0,909 \quad(0,416)$ & 0,449 & $(0,335)$ & $0,594 \quad(0,099)$ \\
\hline Pgm-2 & $-0,689 \quad(0,449)$ & $1,009 \quad(0,213)$ & $-0,022$ & $(0,599)$ & $0,703 \quad(0,361)$ \\
\hline Idh-1 & --- & --- & & -- & --- \\
\hline Skdh & $-0,990 \quad(0,928)$ & $1,963(0,491)$ & 0,000 & $(0,000)$ & $0,000 \quad(0,000)$ \\
\hline G6pdh & --- & --- & 0,392 & $(0,237)$ & $0,983(0,296)$ \\
\hline
\end{tabular}

( ) erro padrão obtido a partir de 100 bootstraps sobre progênies

Tabela 7. Estimativas de índice de fixação e taxa de fecundação cruzada por loco de Trema micrantha, para as populações da Reserva Florestal de Santa Genebra e Estação Ecológica dos Caetetus.

\begin{tabular}{|c|c|c|c|c|c|c|c|c|}
\hline \multirow[t]{2}{*}{ Locos } & \multicolumn{4}{|c|}{ RMSG } & \multicolumn{4}{|c|}{ EEC } \\
\hline & & $\hat{F}$ & & $\hat{t}$ & & $\hat{F}$ & & $\hat{t}$ \\
\hline Gdh-2 & $-0,990$ & $(0,647)$ & 0,807 & $(0,719)$ & 0,990 & $(0,001)$ & 0,000 & $(0,000)$ \\
\hline Skdh & 0,357 & $(0,787)$ & 0,531 & $(0,253)$ & 0,222 & $(0,266)$ & 0,488 & $(0,172)$ \\
\hline Аср-3 & $-0,990$ & $(0,131)$ & 0,887 & $(0,356)$ & $-0,990$ & $(0,155)$ & 1,380 & $(0,205)$ \\
\hline Aсp-2 & $-0,990$ & $(0,001)$ & 0,766 & $(0,166)$ & $-0,607$ & $(0,275)$ & 0,813 & $(0,083)$ \\
\hline Aсp-1 & 0,600 & $(0,84)$ & 0,885 & $(0,217)$ & 0,280 & $(0,719)$ & 0,690 & $(0,248)$ \\
\hline Idh & 0,600 & $(0,860)$ & 0,584 & $(0,121)$ & $-0,990$ & $(0,001)$ & 0,648 & $(0,121)$ \\
\hline Dest & $-0,990$ & $(0,001)$ & 0,848 & $(0,501)$ & $-0,990$ & $(0,001)$ & 0,535 & $(0,196)$ \\
\hline Mdh-2 & 0,749 & $(0,42)$ & 0,688 & $(0,337)$ & $-0,990$ & $(0,893)$ & 1,999 & $(0,657)$ \\
\hline Mdh-3 & 0,990 & $(0,001)$ & & -- & 0,990 & $(0,001)$ & 0,075 & $(0,035)$ \\
\hline Mdh-1 & 0,100 & $(0,599)$ & 0,539 & $(0,188)$ & 0,280 & $(0,672)$ & 0,782 & $(0,324)$ \\
\hline Dia-2 & & - & & -- & $-0,667$ & $(0,208)$ & 0,958 & $(0,301)$ \\
\hline Got & 0,749 & $(0,242)$ & 0,926 & $(0,396)$ & 0,406 & $(0,257)$ & 0,707 & $(0,123)$ \\
\hline G6pdh & 0,100 & $(0,504)$ & 0,959 & $(0,151)$ & $-0,005$ & $(0,367)$ & 1,034 & $(0,199)$ \\
\hline
\end{tabular}

( ) erro padrão obtido a partir de 100 bootstraps sobre progênies 


\subsection{D iscussão}

As taxas de fecundação cruzada não correspondem às expectativas para $C$. pachystachya que, por ser uma espécie dióica, espera-se que todos os eventos de fertilização resultem de fecundação cruzada. As estimativas obtidas se baseiam num conjunto de progênies que apresentam proporções variadas de fecundação cruzada. Da mesma forma que as estimativas se distribuem numa amplitude de variação para as progênies, as estimativas obtidas para locos também apresentaram grande variação entre as taxas de fecundação cruzada e índice de fixação.

As estimativas de índice de fixação expõem elevadas proporções de heterozigotos nos locos analisados para C. pachystachya, estando relacionadas à ocorrência de seleção, sendo uma das possibilidade de violação das pressuposições do modelo de cruzamento misto (Ritland, 1983). Da mesma forma, a grande freqüência de cruzamentos biparentais, o reduzido número de alelos por loco (apenas dois dos sete locos apresentarem três alelos) e as freqüências alélicas distantes de 0,50, também podem ter contribuído para as estimativas pouco consistentes obtidas para $C$. pachystachya. Além disso, segundo Coelho (2002), populações finitas (dezenas de indivíduos) e flutuações nas taxas de cruzamento entre gerações, que é uma realidade em populações naturais, resultam em discrepâncias entre estimativas de índice de fixação para diferentes locos. Tais variações refletem nas estimativas de fecundação cruzada para populações da mesma espécie, devido a elas estarem sujeitas a alterações próprias da espécie e também resultantes de processos estocásticos da natureza.

Desta forma, um conjunto de fatores podem tornar pouco eficiente a aplicação do modelo de cruzamento misto, resultando em estimadores pouco robustos. Para $C$. pachystachya, da mesma forma que as estimativas de fecundação cruzada demonstram tendências, estas também influenciam nos outros parâmetros do sistema de cruzamento, por todos serem estimados a partir de um processo dinâmico e interativo (Ritland \& Jain, 1981). Assim, as estimativas obtidas para os diferentes parâmetros devem ser vistas com cautela. 
As progênies estudadas representam indivíduos localizados em populações, a princípio, bem distintas devido às condições dos fragmentos. A RMSG é um fragmento já bem alterado e de área reduzida, sendo o oposto da EEC. Quando se refere às espécies pioneiras, percebe-se que estas ocorrem com mais freqüência nas condições de ambientes mais alterados. Sobretudo, os exemplares de T. micrantha podem ocorrer individualmente ou em grupos, podendo estes serem bem numerosos, como encontrado no pequeno fragmento próximo à EEC (dezenas de indivíduos adjacentes), ou pequenos, sendo comuns na EEC (média de 3 indivíduos por grupo). A espécie apresenta distribuição espacial agregada, podendo existir indivíduos bem próximos entre si ou mais distantes. Como constatado em campo, a distância entre os indivíduos do mesmo grupo varia também em relação à idade, sendo que indivíduos mais velhos, de copas mais bem formadas e em plena capacidade reprodutiva são mais comuns em grupos menos numerosos e característicos de clareiras mais antigas.

Diante das estimativas, T. micrantha é espécie de cruzamento misto, predominando as fecundações cruzadas e, sendo bem flexível quanto aos seus cruzamentos, podem ser produzidas sementes viáveis mesmo em eventos de autofecundação. Na RMSG verificou-se maior ocorrência de cruzamentos endogâmicos por autofecundação, mas ocorreram proporções semelhantes de cruzamentos biparentais em ambos fragmentos. Devido à variação entre as estimativas dos diferentes parâmetros de sistema de cruzamento, percebe-se que os distúrbios na RMSG favoreceram a ocorrência de autofecundações que, juntamente com a elevada taxa de cruzamentos biparentais, podem trazer prejuízos para esta população da espécie. Por outro lado, os cruzamentos entre indivíduos aparentados revelam a ocorrência de estrutura em família na distribuição espacial dos indivíduos em ambas populações.

A distribuição espacial da espécie e a dispersão de seus grãos de pólen pelo vento podem favorecer cruzamentos entre indivíduos mais próximos cujos períodos de florescimento coincidem. Por outro lado, as autofecundações podem ser viáveis para a permanência da população em casos de isolamento espacial ou assincronismo na floração, justificando o característico hermafroditismo críptico de T. micrantha. Sob tais condições, a fecundação cruzada torna-se função do isolamento espacial dos indivíduos 
reprodutivos, já tendo sido isso discutido para Cavanillesia platanifolia, por Murawski et al. (1990). Sendo esta planta de sucessão inicial polinizada por beija-flor e grandes e pequenas abelhas, que produz frutos dispersados pelo vento, os autores verificaram que indivíduos mantidos em grupos são predominantemente de fecundação cruzada, enquanto os mais isolados têm um maior grau de autofecundação. Seus dados também indicam que as proporções de autofecundação variam de ano para ano, também em função da densidade de árvores reprodutivas nas proximidades. Para C. platanifolia, a heterogeneidade na idade e a distância entre as árvores no dossel tornam menos prováveis os cruzamentos entre as indivíduos aparentados.

T. micrantha apresentou maior índice de fixação na população da RMSG, sugerindo que a fragmentação pode ter resultado num aumento de autofecundações e endogamia na população. Estes efeitos genéticos são mais previsíveis em pequenas populações ocupando habitats isolados, sendo que o aumento da endogamia ou homozigosidade na população pode resultar em depressão endogâmica em espécies predominantemente alógamas, por possuírem altos níveis de carga genética. Murawski et al. (1990), discutindo sobre o estágio sucessional e a condição de compatibilidade, cita que Stebbins (1957) associa a autofecundação à condição de sucessão inicial, estando especialmente presente entre daninhas e espécies colonizadoras. Bawa (1974) afirma que as espécies colonizadoras são sempre de fecundação cruzada e Brown \& Marshall (1981) concordam que praticamente todas elas são auto-compatíveis. Da mesma forma, o dioicismo é um mecanismo de auto-incompatibilidade e está presente em cerca de 24\% das espécies levantadas nas florestas tropicais (Bawa et al.1985b, Ashton, 1969), mas as espécies de sucessão inicial são muito pouco representadas neste grupo.

Considerando um evento de colonização iniciado por poucos indivíduos, os potenciais cruzantes (doadores de pólen) provavelmente estarão amplamente espaçados e, sendo uma espécie dióica, a probabilidade de que o vizinho mais próximo seja do sexo oposto é meio. Por outro lado, sendo espécie hermafrodita, a probabilidade de compatibilidade de cruzamento com o vizinho mais próximo é maior, mesmo se a espécie for auto-incompatível. Se, no entanto, o número de alelos auto-incompatíveis for 
limitado e os cruzamentos aparentados conduzirem para menor fecundidade, as prováveis desvantagens do dioicismo são minimizadas. Isto é particularmente verdade para espécies na qual episódios de colonização são iniciados por muitas sementes de um ou poucos frutos. Para estas, as conseqüências deletérias dos cruzamentos entre irmãos numa espécie auto-incompatível restringem o sucesso da colonização, enquanto o simultâneo estabelecimento de vários indivíduos aumentaria a possibilidade de cruzamentos para plantas dióicas (Anderson \& Stebbins, 1984). Diante de tais considerações, o dioicismo existente na $C$. pachystachya associado à produção de centenas de pequenas sementes dispersas por pássaros e morcegos, garantem a ocorrência de vários co-específicos durante um episódio de colonização. Da mesma forma, o hermafroditismo críptico na T. micrantha também oferece condições eficientes para colonização. No entanto, suas populações podem estar mais vulneráveis às conseqüências da endogamia devido à autofecundação.

Nas espécies florestais, de forma geral, a fragmentação atua diretamente sobre o fluxo gênico intra e inter populacional (Karron et al. 1995). No entanto, para a espécie pioneira T. micrantha, que apresentou maior proporção de cruzamentos endogâmicos e biparentais no menor e mais alterado fragmento, a fragmentação está associada a um maior tamanho absoluto da população. A maior densidade se deve à ação colonizadora da espécie e, por existir menos barreiras de ventos nesta paisagem, a dispersão de pólen pode ser favorecida. Por outro lado, ambas espécies pioneiras estudadas são dependentes de animais e aves para a dispersão de suas sementes. Estes agentes podem ser eficientes na dispersão de propágulos, mas suas populações também estão sujeitas aos impactos da fragmentação, podendo induzir uma dispersão mais ou menos eficiente sobre longas distâncias.

As pesquisas genéticas têm revelado que os grãos de pólen e sementes de árvores tropicais podem atravessar grandes distâncias mesmo em terrenos fragmentados, sugerindo que árvores isoladas espacialmente podem formar ligações vitais entre populações. Aldrich \& Hamrick (1998) demonstraram que árvores de Symphonia globulifera presentes nos pastos podem dominar a reprodução e a regeneração nos remanescentes florestais. Esta espécie de sucessão tardia é polinizada por beija-flores e 
tem suas sementes dispersas por morcegos. Os autores demonstraram que a fragmentação não mantém os indivíduos isolados nos remanescentes florestais. Ao mesmo tempo, surpreenderam-se quando verificaram que 68\% das mudas existentes nos remanescentes foram produzidas pelas plantas adultas dispostas nos pastos que circundavam os remanescentes estudados. Para esta espécie, os autores verificaram que boa parte das sementes produzidas pelas árvores dos pastos foram transportadas por centenas de metros, alcançando os remanescentes florestais das proximidades. Como citado neste trabalho, os morcegos raramente comem nas árvores visitadas, eles carregam frutos para determinados galhos (poleiros) ou os transportam para locais de convívio do grupo para a alimentação de filhotes.

Murawski et al. (1994) consideraram que a ocorrência de espécies arbóreas em grupos na floresta é atípica e anteciparam que este agrupamento aumentaria os níveis de endogamia devido aos cruzamentos entre aparentados e biparentais, se indivíduos dentro do grupo fossem parentes e a dispersão genética fosse limitada. No entanto, seus resultados não apoiaram o esperado e foram justificados pela longa distância de dispersão de pólen, combinado com a dispersão de sementes e, talvez, pela seleção contra progênies endogâmicas. Por outro lado, neste mesmo estudo, os autores também determinaram que as taxas de endogamia, autofecundação e de cruzamentos entre aparentados foram maiores nas florestas perturbadas. Mesmo assim, baseados em avaliações qualitativas, eles verificaram que as árvores das florestas que sofreram distúrbios tiveram maior produção média de frutos e sementes.

Cascante et al. (2002) também realizaram um estudo para avaliar os efeitos da fragmentação numa espécie de árvore tropical (Samanea saman), do grupo inicial de sucessão. Eles integraram parâmetros de biologia reprodutiva com parâmetros de genética de população, que estimam o sistema de cruzamento e níveis de endogamia em progênies de árvores de florestas isoladas e de áreas contínuas. S. saman é polinizada por mariposas noturnas capazes de voar longas distâncias. Os grãos de pólen de cruzamentos nas árvores isoladas vieram de indivíduos distantes de $500 \mathrm{~m}$, sugerindo que esta distância não é uma barreira para fluxo de pólen. Comparações de prováveis irmãos completos entre plantas de áreas contínuas e árvores isoladas sugerem que o 
comportamento do polinizador pode ser afetado pela fragmentação, reduzindo o número de árvores paternais envolvidas na fertilização de óvulos. Os resultados sugeriram que em S. saman a taxa de autofecundação e o coeficiente de endogamia das progênies de árvores isoladas foi maior do que para árvores das populações contínuas. Como conseqüência, seus estudos revelaram significantiva redução na taxa de germinação de sementes, área foliar e biomassa das mudas que compunham as progênies de árvores isoladas.

Menges (1991) e Nason \& Hamrick (1997) também concluíram que as progênies de árvores das populações amostradas nos contínuos florestais foram servidas por mais doadores de pólen do que as progênies de árvores isoladas. Seus resultados, portanto, também revelam o efeito negativo da fragmentação de habitats sobre o vigor das progênies, devido à qualidade e quantidade inferior dos grãos de pólen que fertilizam os óvulos de árvores isoladas.

De qualquer forma, os efeitos demográficos na endogamia e depressão endogâmica dependem do modo de expressão gênica, do estágio do ciclo de vida afetado e da intensidade de seleção contra progênies homozigôticas. Se a depressão endogâmica é severa, podem ser esperados efeitos significativos sobre a viabilidade de populações. Por outro lado, sob algumas circunstâncias, a ação de seleção contra as progênies resultantes de cruzamentos endogâmicos pode resultar na eliminação de alelos deletérios e restaurar o vigor da população (Barrett \& Charlesworth, 1991; Hedrick, 1994). No entanto, estudos comparativos de carga genética em grandes e pequenas populações de plantas têm encontrado poucas evidências à respeito.

As espécies pioneiras foram evolutivamente selecionadas para agir como eficientes colonizadoras. Assim, a produção de grandes quantidades de sementes, resultantes também de cruzamentos endogâmicos, traz vantagens na manutenção da espécie a curto prazo. Por outro lado, a ocorrência de aglomerados de indivíduos estimula severa concorrência favorecendo a permanência dos mais vigorosos. Desta forma, a eliminação de alelos que se tornam deletérios em homozigose deve ser constante nas espécies colonizadoras, resultando em reduzida carga genética e 
possibilitando o estabelecimento de indivíduos endogâmicos, na ausência de competição (Epperson \& Alvarez-Buylla, 1997).

Cruzamentos biparentais são predominantes nas populações de Cecropia pachystachya. Como esta é espécie dióica, variáveis como a densidade e o espaçamento entre as árvores dos diferentes sexos se tornam importantes na eficiência do fluxo gênico em suas populações. Sobretudo, é assunto de complexa discussão e, considerando populações em condições naturais, espera-se proporções iguais e distribuição espacial ao acaso em relação aos indivíduos de diferentes sexos.

Os resultados contrastam com a teoria de que, em populações naturais, existe o predomínio de cruzamentos aleatórios. Por outro lado, apresentando altas taxas de fecundação cruzada e sendo ambas espécies pioneiras, essas características parecem realmente estar associadas à distribuição agregada e ao ciclo de vida curto das espécies deste estágio sucessional. As estimativas indicando cruzamentos entre indivíduos aparentados e cruzamentos biparentais não surpreendem, tratando-se de espécies que apresentam distribuição espacial agregada e contam com a polinização realizada por vento.

De forma geral, o fluxo gênico é mais freqüente em distâncias moderadas de 0,5 a 1 quilômetro, mas também ocorre por distâncias de 2 a 3 quilômetros (Levin \& Kerster, 1974). Hamrick (1982) definiu que, nas populações de espécies arbóreas tropicais, as árvores individuais recebem pólen de relativamente poucos doadores, porém a composição genética de pólen recebido varia grandemente de árvore para árvore, e que uma significativa proporção de pólen alcança relativamente longas distâncias.

Em sua discussão sobre área de vizinhança genética, Boshier et al. (1995) comentam que espécies de árvores tropicais, que ocorrem em baixa densidade, polinizadas por grandes insetos ou morcegos e têm suas sementes dispersas por aves frugívoras e primatas, podem ter área de vizinhança que são de uma ou duas ordens de magnitude maior do que sugerido para populações de Cordia alliodora em ambientes perturbados. Para esta espécie, que é polinizada por insetos e seus frutos são dispersos pelo vento, a área de vizinhança foi definida por 7 ha, sendo que a grande maioria dos 
grãos de pólen alcançam 75 m, mas podem atingir até 280 m. Por outro lado, Hamrick \& Murawski (1990) sugeriram que a unidade de cruzamento efetivo para espécies de árvores tropicais seriam da ordem de 25 a 50 ha.

A polinização por animais predomina entre as espécies de árvores tropicais (Janzen, 1980). No entanto, as espécies dispostas em ambientes mais ventilados, como as gramíneas e ciperáceas, nas savanas, brejos e outros habitats, são beneficiadas pelo transporte dos seus grãos de pólen pelo vento. Nestas condições existe menor diversidade de espécies e as plantas surgem em manchas, diferentemente da regra geral para a maioria das espécies de plantas tropicais. Assim, mesmo sendo um transportador de pólen pouco eficiente, o vento garante a polinização entre indivíduos adjacentes (Janzen, 1980).

A dispersão de pólen ou o fluxo gênico via pólen, em C. obtusifolia, por outro lado, mostrou ser eficiente, sendo o suficiente para homogeneizar a espécie por longas regiões. Para C. obtusifolia verificou-se que grãos de pólen foram recebidos por plantas distantes de mais do que 10 quilômetros (Kaufman et al. 1998). Consequentemente, mesmo populações relativamente isoladas podem receber pólen de populações separadas. Os autores, da mesma forma que Friedman \& Adams (1985) para coníferas, verificaram que o cruzamento entre vizinhos mais próximos predominam; porém, a participação de pólen das populações vizinhas garantiram a produção de $36 \%$ dos descendentes.

\subsection{Conclusões}

As estimativas dos parâmetros de sistemas de cruzamento sugerem que Trema micrantha possui sistema de cruzamento misto com predomínio de fecundação cruzada; que seus indivíduos são dispostos de forma estruturada no espaço, em famílias, e que boa parte dos indivíduos em suas progênies resultam de cruzamentos biparentais, sendo irmãos completos. 
Cecropia pachystachya, que é espécie dióica, também pode apresentar indivíduos estruturados espacialmente em famílias, favorecendo cruzamentos entre indivíduos aparentados. A grande maioria dos indivíduos compondo suas progênies são resultantes de cruzamentos biparentais, sendo irmãos completos.

Como prováveis efeitos da fragmentação e alteração da vegetação, Trema micrantha tende a manter maior endogamia em suas populações e apresentar maiores proporções de cruzamentos correlacionados. 


\section{DIVERSIDADE E ESTRUTURA GENÉTICA EM POPULAÇÕES NATURAIS DE Trema micrantha (L.) B. E Cecropia pachystachya Trec.}

\section{Resumo}

A diversidade e estrutura genética foram estudadas para populações de duas espécies pioneiras: Trema micrantha e Cecropia pachystachya. Populações foram amostradas na Estação Ecológica dos Caetetus (Gália - SP) e na Reserva Florestal Santa Genebra (Campinas - SP), onde se amostrou 177 indivíduos de T. micrantha, distribuídos em 6 e 5 subpopulações, e 178 indivíduos de C. pachystachya, em 2 e 3 subpopulações, nos respectivos fragmentos. A partir das freqüências gênicas obtidas do polimorfismo de aloenzimas para cada espécie, quantificou-se a distribuição da diversidade genética nas populações das espécies. Nesta etapa, somaram-se oito locos polimórficos, num total de 20 alelos, para T. micrantha e sete locos, num total de 17 alelos, para C. pachystachya. Verificou-se que as populações de ambas espécies mantêm baixos níveis de endogamia ( $\hat{f}$ de $-0,052$ e 0,049 em $C$. pachystachya; $-0,204$ e 0,066 em $T$. micrantha) e alta diversidade ( $\hat{H}_{e}$ de 0,355 e 0,335 em C. pachystachya; 0,373 e 0,392 em T. micrantha). A divergência genética estimada entre populações é menor do que entre subpopulações ( $\hat{\theta}_{p}$ de 0,026 e $-0,007, \hat{\theta}_{S P}$ de 0,086 e 0,068 para C. pachystachya e T. micrantha, respectivamente). Os resultados sugerem forte seleção atuando dentro de clareiras favorecendo a manutenção de elevada heterozigosidade na população do fragmento mais alterado. Da mesma forma, a distribuição espacial em clareiras é importante para preservar a diversidade genética e se verificou que a participação dos agentes dispersores de sementes é fundamental na realização do fluxo gênico nestas espécies. 


\section{Summary}

[Diversity and genetic structure in natural populations of Trema micrantha Trec. and Cecropia pachystachya (L.)B.]

The diversity and genetic structure were studied for populations of two pioneer tree species: Trema micrantha and Cecropia pachystachya. The study was conducted with populations of the “Estação Ecologica dos Caetetus” (Gália, São Paulo State, Brazil) and from the "Reserva Florestal de Santa Genebra” (Campinas, São Paulo State, Brazil) where 177 plants of T. micrantha, distributed in six and five subpopulations, and 178 plants of C. pachystachya, distributed in two and three subpopulations, were sampled from both fragments, respectively. Eight polymorphic loci with 20 alleles for $T$. micrantha and seven loci with 17 alleles for $C$. pachystachya were used to estimate diversity and genetic structure. The results indicated that populations of both species have low levels of inbreeding ( $\hat{f}=-0.052$ and 0.049 in C. pachystachya, from both fragments respectively; $\hat{f}=-0.204$ and 0.066 in $T$. micrantha) and high diversity index ( $\hat{H}_{e}=0.355$ and 0.335 in C. pachystachya; $\hat{H}_{e}=0.373$ and 0.392 in T. micrantha, from both fragments respectively). The genetic divergence among populations is lower than among subpopulations $\left(\hat{\theta}_{p}=0.026\right.$ and $-0.007, \hat{\theta}_{S P}=0.086$ and 0.068 for $C$. pachystachya and T. micrantha, respectively). These results suggest a strong selection acting within gaps and favoring the maintenance of high heterozygosity in the population of the most altered fragment. Similarly, the spatial distribution in gaps is important to preserve the genetic diversity in these species and it was verified that the seed dispersal agents are important in the achievement of gene flow in these species.

\subsection{Introdução}

Muitas pesquisas sobre a dinâmica de florestas tropicais têm sido desenvolvidas de forma acelerada devido à grande pressão antrópica sobre seus ecossistemas. Por 
apresentar alto nível de diversidade biológica, é um grande desafio entender sua estrutura, considerando a organização das comunidades, a dinâmica das populações, bem como as especiações e as variações fisiológicas que atribuem características demográficos e comportamentais que sustentam toda sua complexidade. Sobretudo, a dinâmica de regeneração tem merecido particular atenção devido sua grande importância no manejo florestal (Bazzaz, 1991).

Tem se observado muitas mudanças na composição de espécies de comunidades florestais, resultantes da constante fragmentação dos contínuos florestais (Murcia, 1995). Percebe-se que, com a fragmentação, ocorre imediata redução do número de indivíduos nas espécies, no tamanho médio de suas populações e, como os indivíduos podem se tornar restritos a pequenos fragmentos, pode resultar em isolamento espacial entre populações remanescentes. Tais alterações refletem nos processos de deriva genética, fluxo gênico, seleção e no sistema de cruzamentos. Sendo esses processos determinantes da quantidade de diversidade genética na espécie, bem como sua distribuição entre indivíduos e populações, os três principais e possíveis efeitos genéticos da fragmentação florestal são a diminuição da diversidade genética nas populações e espécies, a mudança na estrutura genética populacional e o aumento da endogamia, que acarretam fortes prejuízos às populações e às espécies florestais (Young \& Boyle, 2001; Primack \& Rodrigues, 2001).

Por outro lado, estimativas de fluxo gênico interpopulacional, por métodos indiretos, têm indicado elevadas incidências de troca gênica entre populações distantes, mesmo considerando centenas de quilômetros (Hamrick \& Loveless, 1989). Similarmente, as estimativas diretas de distância de dispersão de pólen e sementes em florestas primárias mostram que o fluxo gênico é realmente eficiente, destacando-se espécies que possuem interações com agentes dispersores que apresentam grandes áreas de forrageamento (Loveless, 1992; Boshier et al. 1995). Dessa forma, as possíveis conseqüências diante do efeito da fragmentação variam em ralação às características de história de vida, abundância, longevidade e sistema de cruzamento das espécies. Além disso, os efeitos ainda podem ser diferentes e mais complicados de interpretação, devido 
às interações com outras espécies, que também podem estar sofrendo os efeitos da fragmentação (Nason \& Hamrick, 1997).

O processo de sucessão ecológica, que é a forma como as florestas se regeneram, envolve um conceito amplo e que pode servir como critério para classificar as espécies em grupos básicos como pioneiras, secundárias e clímax (Budowski, 1965). Sob o ponto de vista de paisagens fragmentadas, as espécies pioneiras têm-se tornado cada vez mais freqüentes nas florestas e também fora delas. Nas florestas, sua presença está associada à taxa de substituição de árvores, o que subentende-se abertura de clareiras de diferentes dimensões e por vários motivos (Whitmore, 1991). Fora delas, além das espécies pioneiras estarem presentes em pequenas manchas de vegetação na paisagem, a maioria delas possui características desejáveis para compor os diversos tipos de programas de restauração vegetal, estando cada vez mais presentes fora das suas condições naturais.

Espécies pioneiras possuem características próprias de extinção local e recolonização, o que pode contribuir efetivamente para o aumento do fluxo gênico, reduzindo a diferenciação genética entre populações (Slatkin, 1985, 1987). A existência de banco de sementes e a longa distância de dispersão de pólen e sementes apresentam importantes conseqüências genéticas e ecológicas para as espécies. Exemplos claros são os bancos de sementes poderem agir como um tampão gênico devido sua capacidade de repor a variação genética perdida pela população de plantas após a extinção local, e a longa distância de dispersão de sementes e pólen poderem reduzir a distância entre populações geograficamente distantes (Alvarez-Buylla \& Garay, 1994).

Sob esse aspecto, torna-se importante o conhecimento da estrutura genética de populações de espécies pioneiras. Este conhecimento resultaria em maiores subsídios para se planejar a melhor maneira de realizar o seu manejo, desenvolver programas para coletas de sementes de forma adequada ao uso de tais espécies em projetos de restauração de áreas degradadas, bem como na formação de corredores de fluxo gênico.

Uma das formas ainda mais utilizadas para se quantificar a diversidade genética em populações naturais é baseado no polimorfismo em locos que codificam proteínas específicas, sendo acessado por meio de eletroforese de isoenzimas. Com as informações obtidas a partir da aplicação desta técnica, também é possível entender como a 
diversidade está distribuída nas populações de interesse que compõem a amostra (Alfenas et al. 1998).

Diante do exposto, este trabalho foi desenvolvido com o objetivo de quantificar e entender a distribuição da diversidade genética em populações de duas espécies pioneiras típicas (Trema micrantha e Cecropia pachystachya), sendo avaliadas pelo polimorfismo obtido através da eletroforese de isoenzimas. Os resultados obtidos são discutidos considerando-se as características ecológicas das espécies e o efeito da fragmentação dos contínuos florestais sobre a viabilidade das populações dessas espécies pioneiras arbóreas.

\subsection{Material e métodos}

\subsubsection{Espécies estudadas}

Foram amostradas populações de duas espécies pioneiras típicas e representativas da Mata Atlântica, Cecropia pachystachya Trec. e Trema micrantha (L.) B.. T. micrantha ocorre em variados tipos de ambientes, exceto nos mais úmidos. É uma das primeiras espécies a se estabelecer em áreas abandonadas, continuando a existir em todos os estágios da sucessão secundária, exceto na floresta madura (Lorenzi, 1992). Ocorre naturalmente entre as latitudes $30^{\circ} \mathrm{N}$ (Estados Unidos) e $30^{\circ} \mathrm{S}$ (Brasil), e é classificada como hermafrodita críptica por possuir indivíduos variando de monóicos a dióicos e suas flores serem unissexuadas ou bissexuadas andrógenas (Torres, 1996). Suas flores são polinizadas principalmente pelo vento, podendo também ser visitadas por pequenos insetos (Bawa et al. 1985a), enquanto a dispersão das sementes é por zoocoria, principalmente por aves (Carvalho, 1994).

Já C. pachystachya é planta dióica que pode atingir 4 a $7 \mathrm{~m}$ de altura e 15 a 25 cm de diâmetro. Esta espécie é pioneira e seletiva higrófita que ocorre em várias formações florestais, sendo encontrada desde o Ceará até Santa Catarina. É raro encontrá-la no interior da mata primária densa, sendo mais comum em matas 
secundárias e também em capoeiras novas situadas junto a vertentes ou cursos d’água. Seus grãos de pólen também são dispersos pelo vento e a espécie produz uma grande quantidade de sementes que são dispersas por ampla diversidade de pássaros (Lorenzi, 1992), morcegos e outros frugívoros.

\subsubsection{Locais de estudo}

As populações estudadas foram amostradas na Estação Ecológica dos Caetetus (EEC) e na Reserva Florestal de Santa Genebra (RMSG). A EEC é administrada pelo Instituto Florestal de São Paulo e está situada entre a latitude $22^{\circ} 22^{\prime}$ a $22^{\circ} 27^{\prime}$ Sul e longitude $49^{\circ} 40^{\prime}$ e $49^{\circ} 43^{\prime}$ Oeste, entre os municípios de Gália e Alvilândia-SP. Ela compreende uma área de 2.179 ha de floresta tropical latifoliada semidecídua, com características primárias e espécies típicas desse tipo de floresta do centro-oeste do Estado. Nela, encontram-se árvores com alturas de até 25 a 30 m e diâmetros de $1 \mathrm{~m}$, sendo que, a flora local é considerada praticamente intacta, representando um dos maiores e mais conservados remanescentes deste tipo de floresta em todo o Estado de São Paulo (Perecin, 2000).

A RMSG possui 251,8 ha de floresta tropical estacional semidecídua (IBGE, 1993), localizados nas coordenadas $22^{\circ} 49^{\prime} 45^{\prime}$ ' S e $47^{\circ} 06^{\prime} 33^{\prime}$ ' W, no município de Campinas-SP. Ao longo de sua área levemente ondulada, com altitudes variando de 580

a 610 m, verifica-se um mosaico de vegetação, em que várias fases sucessionais são encontrados. Ocorrem tanto áreas com floresta preservada, formando um dossel contínuo de 15 a 18 metros de altura e com espécies emergentes de até 25 m, como áreas muito perturbadas, ocupadas por espécies de estágio sucessional inicial. Além destas, encontram-se áreas mais baixas com solos permanentemente encharcados ocupados por uma Floresta Paludosa. Neste pequeno fragmento, além dos processos naturais que estimulam a regeneração, ocorreram perturbações antrópicas como queimadas, extração seletiva de madeiras nobres e corte raso de alguns pequenos trechos para utilização da lenha (Leitão-Filho, 1995). 


\subsubsection{Amostragem}

Amostrou-se 178 indivíduos de T. micrantha e 177 de C. pachystachya. Da primeira espécie, 96 indivíduos representam a população da RMSG e os outros 82 a EEC. Para C. pachystachya, 94 e 83 indivíduos foram amostrados representando as populações de ambos fragmentos, respectivamente. As amostragens foram realizadas considerando os indivíduos dispostos em diferentes clareiras como sendo subpopulações dentro das duas populações, para ambas espécies. Dessa forma, a população de $T$. micranta foi amostrada na EEC diferenciando-se cinco subpopulações, sendo quatro localizadas ao longo de uma estreita estrada que corta longitudinalmente todo o fragmento e uma quinta subpopulação em um pequeno fragmento distante 1,7 quilômetro da borda do fragmento da EEC. Ainda na EEC, a população de $C$. pachystachya está representada por indivíduos amostrados em dois brejos, considerados como duas subpopulações localizadas na borda da floresta, estando cercados por lavouras de café da fazenda vizinha.

A população de T. micrantha amostrada na RMSG foi considerada como seis subpopulações constituindo dois tipos de clareiras. Quatro destas clareiras se caracterizam como grandes áreas abertas, provavelmente pela extração de madeira e pela ocorrência de queimadas num passado recente. Outras duas subpopulações ocorrem em condição menos alterada, em pequenas clareiras formadas pela abertura de trilhas para visitação. Verificou-se que aquelas quatro subpopulações possuíam árvores mais distantes entre si, além de mais velhas do que essas outras duas. Na RMSG, a população de C. pachystachya é representada por três subpopulações localizados em brejos.

\subsubsection{Protocolos}

Coletou-se folhas jovens de plantas adultas para análise genética em laboratório. As folhas de T. micrantha foram acondicionadas em caixa de isopor contendo gelo. Diferentemente, as folhas de C. pachystachya exigiram que, logo após retiradas da 
planta, fossem envolvidas em papel alumínio e imersas em nitrogênio líquido. O tecido foliar coletado de indivíduos de ambas espécies foi macerado após chegar ao LARGEA (Laboratório de Reprodução e Genética de Espécies Arbóreas), na ESALQ/USP. Durante a extração, utilizou-se o tampão 1, citado em Alfenas et al. (1991). As amostras foram mantidas em freezer $-80^{\circ} \mathrm{C}$, na forma de "wiks", até o momento de serem submetidas à eletroforese de isoenzimas. A eletroforese horizontal de isoenzimas foi realizada em géis de $400 \mathrm{ml}$ contendo penetrose $(34,29 \mathrm{~g})$ e amido de batata $(18,29 \mathrm{~g})$. Inicialmente, testou-se quatro sistemas tampão gel/eletrodo com 32 sistemas enzimáticos para ambas espécies.

Diante das avaliações da atividade enzimática e resolução dos zimogramas para T. micrantha, revelou-se as enzimas malato desidrogenase (MDH, EC-1.1.1.37), glucose desidrogenase (GDH, EC-1.1.1.47), xiquimato desidrogease (SKDH, EC1.1.1.25), NADH-desidrogenase (NADHDH, EC-1.6.99.3), diaforase (DIA, EC1.8.1.4), menadiona redutase (MR, EC-1.6.99.2), isocitrato desidrogenase (IDH, EC1.1.1.42) e glutamato oxaloacetato transaminase (GOT, EC-2.6.1.1). A eletroforese foi realizada sob o sistema tampão gel/eletrodo número 25, citado em Alfenas et al. (1991). Nesta etapa, selecionaram-se 8 locos polimórficos, num total de 20 alelos.

Para as amostras de C. pachystachya revelou-se as enzimas fosfogluco isomerase (PGI, EC-5.3.1.9), malato desidrogenase (MDH, EC-1.1.1.37), peroxidase (PO, EC1.11.1.7), isocitrato desidrogenase (IDH, EC-1.1.1.42) e xiquimato desidrogease (SKDH, EC-1.1.1.25). Para esta espécie, a eletroforese foi realizada com o sistema tampão gel/eletrodo número 25, quando se obteve a revelação das três primeiras enzimas, e com o sistema 3, para as últimas duas enzimas. Nas análises trabalhou-se com 7 locos isoenzimáticos polimórficos e um total de 17 alelos.

\subsubsection{Análises estatísticas}

A partir das freqüências alélicas e genotípicas, obteve-se os seguintes índices de diversidade genética intrapopulacional: número de alelos por locos $(A)$, heterozigosidade esperada sob as condições de Equilíbrio de Hardy-Weinberg (E.H.W.) ou diversidade 
gênica $\left(H_{e}\right)$, heterozigosidade observada $\left(H_{o}\right)$ e o coeficiente de endogamia intrapopulacional $(f)$.

A estrutura genética avaliada em três níveis hierárquicos, considerando indivíduos dentro de subpopulações dispostas nas população da RMSG e da EEC, foi caracterizada pela análise da variância das freqüências gênicas (Weir, 1996). Os parâmetros estimados foram: índice de fixação médio dentro das populações ( $f$ ); índice de fixação total da espécie $(F)$; o coeficiente de coancestralidade entre indivíduos dentro de populações ou divergência genética entre populações $\left(\theta_{P}\right)$ e coeficiente de coancestralidade entre indivíduos dentro de subpopulações ou divergência genética entre subpopulações $\left(\theta_{S P}\right)$. A significância estatística dos parâmetros foi estimada pelo intervalo de confiança a 95\% de probabilidade, obtido por reamostragem bootstrap, utilizando-se 1.000 repetições sobre locos. Os parâmetros relacionados acima e os bootstraps foram estimados com o auxílio do programa GDA de Lewis \& Zaykin (1999).

O fluxo gênico aparente $\left(\hat{N}_{m}\right)$ entre populações e subpopulações foi estimado de forma indireta, segundo método proposto por Crow e Aoki (1984), o qual corrige a análise realizada com pequeno número de populações: $\left.\hat{N}_{m}=(1 / 4 \alpha)\left[1 / \hat{F}_{s t}\right)-1\right]$, em que $\hat{N}_{m}$ corresponde ao número de migrantes por geração, $\hat{F}_{s t}$ a divergência genética entre populações e $\alpha$ a correção para o número de populações (n), sendo: $\alpha=[n /(n-1)]^{2}$. Substituiu-se por $\hat{\theta}_{p}$ conforme sugerem Cockerham \& Weir (1993), para uma estimação de fluxo gênico não viesada.

Testando a hipótese de que a distribuição das freqüências dos alelos é idêntica nas subpopulações estudadas, recorreu-se ao programa TFPGA (Miller, 1997), o qual possibilitou utilizar a metodologia descrita por Raymond \& Rousset (1995), empregando reamostragem numérica do tipo Cadeias de Markov. O procedimento testa a homogeneidade do padrão de distribuição das freqüências alélicas entre as subpopulações, analisando loco a loco e assume que as freqüências provenientes de cada loco são independentes entre si. Para o procedimento, utilizou-se 10 baterias de testes, 
com 1.000 permutações por bateria e 1.000 passos de desmemorização. Comparou-se todas as subpopulações em pares separadamente para T. micrantha e C. pachystachya.

\subsection{Resultados}

\subsubsection{Freqüências alélicas}

As freqüências alélicas nos oito locos polimórficos analisados para T. micrantha apresentam variações entre as onze subpopulações estudadas (Tabela 8). No loco Mdh-1, o alelo a foi exclusivo para duas subpopulações de RMSG e o alelo $\underline{b}$ foi o mais freqüente entre populações estudadas, estando fixado na subpopulação 2 deste fragmento. O alelo a do loco Gdh-2 se mostrou fixado em cinco subpopulações, enquanto este apresentou a mesma freqüência que o alelo b na subpopulação 11 . Curiosamente, o alelo $\underline{c}$ do Skdh esteve presente nas cinco subpopulações da EEC, enquanto o mesmo foi exclusivo da subpopulação 6, na RMSG.

Dadas as freqüências alélicas nos sete locos analisados para C. pachystachya (Tabela 9), apenas o loco Mdh-2 apresenta alelo fixado em uma das subpopulações estudadas. Da mesma forma, para esta espécie não houve casos de alelos exclusivos para nenhum dos seus locos.

O teste de diferenciação foi aplicado com a hipóstese de nulidade para distribuição semelhante das freqüências alélicas nas subpopulações consideradas. Desta forma, considerando-se 95\% de probabilidade, boa parte das comparações apresentaram diferenças significativas (Tabelas 10 e 11).

Para T. micrantha, dos 55 confrontos, 40\% foi significativo, chamando-se atenção para as subpopulações 1-1, 1-2, 1-3 e 1-6. Por outro lado, a maioria dos confrontos indicaram probabilidade de semelhança entre as subpopulações desta espécie. 
Tabela 8. Freqüências alélicas nos respectivos locos isoenzimáticos analisados nas onze subpopulações de plantas adultas de Trema micrantha.

\begin{tabular}{|c|c|c|c|c|c|c|c|c|c|c|c|}
\hline \multicolumn{12}{|c|}{ Subpopulações } \\
\hline Locos & 1 & 2 & 3 & 4 & 5 & 6 & 7 & 8 & 9 & 10 & 11 \\
\hline \multicolumn{12}{|c|}{ Mdh-1 } \\
\hline$(\mathrm{N})$ & 16 & 10 & 13 & 15 & 11 & 30 & 7 & 15 & 8 & 14 & 37 \\
\hline $\mathrm{a}$ & 0,000 & 0,000 & 0,038 & 0,000 & 0,000 & 0,033 & 0,000 & 0,000 & 0,000 & 0,000 & 0,000 \\
\hline $\mathrm{b}$ & 0,906 & 1,000 & 0,962 & 0,933 & 0,955 & 0,950 & 1,000 & 0,933 & 0,938 & 0,964 & 0,959 \\
\hline C & 0,094 & 0,000 & 0,000 & 0,067 & 0,045 & 0,017 & 0,000 & 0,067 & 0,063 & 0,036 & 0,041 \\
\hline \multicolumn{12}{|c|}{ Gdh-2 } \\
\hline$(\mathrm{N})$ & 13 & 6 & 13 & 14 & 7 & 27 & 7 & 14 & 7 & 9 & 19 \\
\hline a & 0,962 & 1,000 & 0,923 & 0,893 & 0,929 & 0,963 & 1,000 & 1,000 & 1,000 & 1,000 & 0,500 \\
\hline $\mathrm{b}$ & 0,038 & 0,000 & 0,077 & 0,107 & 0,071 & 0,037 & 0,000 & 0,000 & 0,000 & 0,000 & 0,500 \\
\hline \multicolumn{12}{|l|}{ Skdh } \\
\hline$(\mathrm{N})$ & 14 & 5 & 13 & 13 & 4 & 26 & 7 & 15 & 8 & 14 & 28 \\
\hline a & 0,143 & 0,500 & 0,500 & 0,462 & 0,500 & 0,365 & 0,143 & 0,333 & 0,438 & 0,321 & 0,518 \\
\hline b & 0,857 & 0,500 & 0,500 & 0,538 & 0,500 & 0,615 & 0,643 & 0,500 & 0,500 & 0,607 & 0,429 \\
\hline C & 0,000 & 0,000 & 0,000 & 0,000 & 0,000 & 0,019 & 0,214 & 0,167 & 0,063 & 0,071 & 0,054 \\
\hline \multicolumn{12}{|c|}{ Nadhdh } \\
\hline$(\mathrm{N})$ & 16 & 9 & 13 & 15 & 11 & 30 & 7 & 15 & 8 & 13 & 1 \\
\hline $\mathrm{a}$ & 0,000 & 0,722 & 0,692 & 0,533 & 0,545 & 0,183 & 0,071 & 0,267 & 0,188 & 0,346 & 0,000 \\
\hline $\mathrm{b}$ & 1,000 & 0,278 & 0,308 & 0,467 & 0,455 & 0,817 & 0,929 & 0,733 & 0,813 & 0,654 & 1,000 \\
\hline \multicolumn{12}{|l|}{ Dia-2 } \\
\hline$(\mathrm{N})$ & 16 & 9 & 12 & 15 & 11 & 29 & 7 & 14 & 8 & 12 & 22 \\
\hline $\mathrm{a}$ & 0,344 & 0,611 & 0,458 & 0,367 & 0,318 & 0,276 & 0,357 & 0,357 & 0,313 & 0,375 & 0,386 \\
\hline b & 0,375 & 0,278 & 0,500 & 0,333 & 0,227 & 0,638 & 0,429 & 0,429 & 0,313 & 0,458 & 0,432 \\
\hline c & 0,281 & 0,111 & 0,042 & 0,300 & 0,455 & 0,086 & 0,214 & 0,214 & 0,375 & 0,167 & 0,182 \\
\hline \multicolumn{12}{|l|}{$\mathrm{Mr}$} \\
\hline$(\mathrm{N})$ & 8 & 9 & 12 & 14 & 11 & 28 & 4 & 9 & 7 & 11 & 1 \\
\hline $\mathrm{a}$ & 0,188 & 0,611 & 0,583 & 0,429 & 0,409 & 0,304 & 0,250 & 0,389 & 0,214 & 0,273 & 0,000 \\
\hline b & 0,750 & 0,278 & 0,417 & 0,357 & 0,318 & 0,679 & 0,750 & 0,500 & 0,571 & 0,500 & 1,000 \\
\hline c & 0,063 & 0,111 & 0,000 & 0,214 & 0,273 & 0,018 & 0,000 & 0,111 & 0,214 & 0,227 & 0,000 \\
\hline \multicolumn{12}{|l|}{ Idh } \\
\hline$(\mathrm{N})$ & 16 & 8 & 12 & 15 & 11 & 29 & 7 & 15 & $8(\mathrm{~N})$ & 14 & 38 \\
\hline $\mathrm{a}$ & 0,094 & 0,438 & 0,083 & 0,200 & 0,182 & 0,310 & 0,286 & 0,233 & 0,250 & 0,286 & 0,250 \\
\hline b & 0,906 & 0,563 & 0,917 & 0,800 & 0,818 & 0,690 & 0,714 & 0,767 & 0,750 & 0,714 & 0,750 \\
\hline \multicolumn{12}{|l|}{ Got } \\
\hline a & 0,656 & 0,750 & 0,667 & 0,567 & 0,591 & 0,875 & 0,500 & 0,500 & 0,813 & 0,821 & $\begin{array}{l}1 \\
1,000\end{array}$ \\
\hline $\mathrm{b}$ & 0,344 & 0,250 & 0,333 & 0,433 & 0,409 & 0,125 & 0,500 & 0,500 & 0,188 & 0,179 & 0,000 \\
\hline
\end{tabular}

Subpopulações de 1 a 6 : Reserva Florestal de Santa Genebra

Subpopulações de 7 a 11 : Estação Ecológica dos Caetetus

$\mathrm{N}$ : Número de indivíduos analisados por subpopulação, nos respectivos locos 
Tabela 9. Freqüências alélicas nos respectivos locos isoenzimáticos analisados nas cinco subpopulações de plantas adultas de Cecropia pachystachya .

\begin{tabular}{|c|c|c|c|c|c|}
\hline \multicolumn{6}{|c|}{ Subpopulações } \\
\hline Locos & 1 & 2 & 3 & 4 & 5 \\
\hline \multicolumn{6}{|l|}{ Pgi-1 } \\
\hline$(\mathrm{N})$ & 28 & 26 & 34 & 42 & 39 \\
\hline $\mathrm{a}$ & 0,732 & 0,808 & 0,779 & 0,893 & 0,782 \\
\hline $\mathrm{b}$ & 0,268 & 0,192 & 0,221 & 0,107 & 0,218 \\
\hline \multicolumn{6}{|c|}{ Pgi-3 } \\
\hline$(\mathrm{N})$ & 30 & 29 & 33 & 40 & 39 \\
\hline $\mathrm{a}$ & 0,000 & 0,052 & 0,061 & 0,025 & 0,026 \\
\hline $\mathrm{b}$ & 0,050 & 0,155 & 0,076 & 0,063 & 0,000 \\
\hline c & 0,950 & 0,793 & 0,864 & 0,913 & 0,974 \\
\hline \multicolumn{6}{|l|}{ Idh } \\
\hline$(\mathrm{N})$ & 26 & 27 & 33 & 39 & 37 \\
\hline $\mathrm{a}$ & 0,615 & 0,222 & 0,379 & 0,615 & 0,595 \\
\hline $\mathrm{b}$ & 0,385 & 0,778 & 0,621 & 0,385 & 0,405 \\
\hline \multicolumn{6}{|c|}{ Mdh-1 } \\
\hline$(\mathrm{N})$ & 28 & 27 & 34 & 42 & 39 \\
\hline $\mathrm{a}$ & 0,107 & 0,426 & 0,118 & 0,190 & 0,462 \\
\hline $\mathrm{b}$ & 0,893 & 0,574 & 0,882 & 0,810 & 0,538 \\
\hline \multicolumn{6}{|c|}{ Mdh-2 } \\
\hline$(\mathrm{N})$ & 28 & 28 & 34 & 41 & 39 \\
\hline $\mathrm{a}$ & 0,000 & 0,286 & 0,059 & 0,134 & 0,385 \\
\hline b & 1,000 & 0,679 & 0,941 & 0,854 & 0,603 \\
\hline c & 0,000 & 0,036 & 0,000 & 0,012 & 0,013 \\
\hline \multicolumn{6}{|l|}{ Po-1 } \\
\hline$(\mathrm{N})$ & 27 & 26 & 32 & 41 & 37 \\
\hline $\mathrm{a}$ & 0,426 & 0,481 & 0,500 & 0,634 & 0,635 \\
\hline $\mathrm{b}$ & 0,537 & 0,442 & 0,500 & 0,341 & 0,297 \\
\hline c & 0,037 & 0,077 & 0,000 & 0,024 & 0,068 \\
\hline \multicolumn{6}{|l|}{ Skdh } \\
\hline$(\mathrm{N})$ & 26 & 21 & 25 & 33 & 37 \\
\hline $\mathrm{a}$ & 0,712 & 0,595 & 0,780 & 0,909 & 0,865 \\
\hline b & 0,288 & 0,405 & 0,220 & 0,091 & 0,135 \\
\hline
\end{tabular}

Subpopulações de 1 a 3 : Reserva Florestal de Santa Genebra Subpopulações de 4 e 5 : Estação Ecológica dos Caetetus $\mathrm{N}$ : Número de indivíduos analisados por subpopulação, nos respectivos locos; 
Ainda para T. micrantha, as combinações entre as subpopulações representando o mesmo fragmento, curiosamente, indicaram resultados contrastantes entre os fragmentos estudados. Para as subpopulações da EEC, verificou-se semelhança entre as mesmas, mesmo para a subpopulação 2-5, que se encontra mais distante do fragmento. Por outro lado, $40 \%$ dos contrastes para as subpopulações da RMSG foram significativas. A subpopulação 1-1, por exemplo, mostrou-se distinta em relação a todas as outras consideradas neste fragmento.

Para C. pachystachya apenas um contraste indicou alguma tendência à semelhança entre as subpopulações, estando ambas na RMSG. Com este teste, verificase que existe diferenças significativas entre as subpopulações de $C$. pachystachya.

De forma geral, os resultados indicam que existem variações não ao acaso na distribuição das freqüências gênicas, comparativamente entre as subpopulações das espécies estudadas. Para T. micrantha, por outro lado, as variações verificadas entre as subpopulações amostradas na RMSG não se repetiram entre as subpopulações amostradas na EEC. 
Tabela 10. Matriz de probabilidades, obtidas sobre 8 locos, combinadas para cada par comparativo de 11 subpopulações de Trema micrantha.

\begin{tabular}{lccccccccccc}
\hline & $1-1$ & $1-2$ & $1-3$ & $1-4$ & $1-5$ & $1-6$ & $2-1$ & $2-2$ & $2-3$ & $2-4$ & $2-5$ \\
$1-1$ & ------ & & & & & & & & & & \\
$1-2$ & 0,0000 & ------ & & & & & & & & & \\
$1-3$ & 0,0001 & 0,6062 & ------ & & & & & & & & \\
$1-4$ & 0,0015 & 0,3980 & 0,2770 & ------ & & & & & & \\
$1-5$ & 0,0020 & 0,5445 & 0,0913 & 1,0000 & ------ & & & & & & \\
$1-6$ & 0,0001 & 0,0002 & 0,0003 & 0,0000 & 0,0000 & ------ & & & & \\
$2-1$ & 0,3558 & 0,0019 & 0,0003 & 0,0214 & 0,0670 & 0,0701 & ------ & & & & \\
$2-2$ & 0,0328 & 0,0164 & 0,0017 & 0,2623 & 0,2480 & 0,0052 & 0,9919 & ------ & & & \\
$2-3$ & 0,1062 & 0,0759 & 0,0040 & 0,4533 & 0,6876 & 0,3059 & 0,6981 & 0,8339 & ------ & & \\
$2-4$ & 0,0014 & 0,3474 & 0,0159 & 0,2659 & 0,4010 & 0,3158 & 0,3333 & 0,6409 & 0,9977 & ------- & \\
$2-5$ & 0,0032 & 0,3053 & 0,0074 & 0,3375 & 0,9394 & 0,0011 & 0,1302 & 0,5352 & 0,9994 & 0,6449 & ------ \\
& & & & & & & & & & &
\end{tabular}

População RMSG, subpopulação 1

População RMSG, subpopulação 2

População RMSG, subpopulação 3

População RMSG, subpopulação 4

População RMSG, subpopulação 5

População RMSG, subpopulação 6
2-1 População EEC, subpopulação 1

2-2 População EEC, subpopulação 2

2-3 População EEC, subpopulação 3

2-4 População EEC, subpopulação 4

2-5 População EEC, subpopulação 5

Tabela 11. Matriz de probabilidades combinadas, obtidas sobre 7 locos, para cada par comparativo de 5 subpopulações de Cecropia pachystachya.

\begin{tabular}{cccccc}
\hline & $1-1$ & $1-2$ & $1-3$ & $2-1$ & $2-2$ \\
$1-1$ & ------- & & & & \\
$1-2$ & 0,0000 & ------- & & & \\
$1-3$ & 0,1126 & 0,0000 & ------ & & \\
$2-1$ & 0,0006 & 0,0000 & 0,0032 & ------ & \\
$2-2$ & 0,0000 & 0,0000 & 0,0000 & 0,0001 & ------- \\
\hline
\end{tabular}

1-1 População RMSG, subpopulação 1

1-2 População RMSG, subpopulação 2

1-3 População RMSG, subpopualção 3
2-1 População EEC, subpopulação 1

2-2 População E.E.E., subpopulação 2 


\subsubsection{Diversidade genética}

Como se pode verificar na Tabela 12, as estimativas de heterozigosidade foram bem altas em ambas espécies, sendo que, nas populações da RMSG, a heterozigosidade observada foi maior do que se esperava, sob as proporções de E.H.W. (0,446 e 0,373 para T. micrantha, 0,373 e 0,355 para C. pachystachya, respectivamente). Já na EEC, as estimativas de heterozigosidade observada foram menores do que se esperava (0,366 e 0,392 para T. micrantha; 0,319 e 0,335 para C. pachystachya, respectivamente), indicando excesso de genótipos homozigotos. A partir da estimativa de número médio de alelos por locos, T. micrantha apresentou 75\% da heterozigosidade máxima possível nestas populações (0,411 para o máximo de 0,548). Já as populações de $C$. pachystachya apresentaram 63,76\% da heterozigosidade máxima (0,351 para o máximo de 0,551).

As estimativas do índice de fixação intrapopulacional foram positivas e próximas de zero para as populações da EEC (0,066 e 0,049 para T. micratha e C. pachystachya, respectivamente), enquanto as estimativas referentes às populações localizadas na RMSG foram negativas (-0,204 e -0,052 para T. micratha e C. pachystachya, respectivamente). As estimativas negativas indicam que existe um favorecimento aos genótipos heterozigotos dentro das subpopulações analisadas, sendo que este pode indicar um processo de seleção atuando de forma mais severa na população da RMSG. De qualquer forma, houve grande variação no índice de fixação para os pequenos grupos de indivíduos analisados como subpopulações, sendo que nove das onze subpopulações de T. micrantha e quatro das cinco de C. pachystachya indicaram existir desvios nas proporções de genótipos observados em relação aos esperados sob condições de E.H.W., considerando os valores positivos ou negativos, maiores que $5 \%$. 
Tabela 12. Estimativas para os parâmetros de diversidade genética intrapopulacional, estando apresentados o número de indivíduos amostrados na subpopulação (n) número de alelos por locos $(A)$, heterozigosidade média observada $\left(H_{o}\right)$, heterozigosidade média esperada $\left(H_{e}\right)$ e coeficiente de endogamia ( $f$ ), para ambas espécies estudadas, nos diferentes locais de estudo, a partir de marcadores isoenzimáticos.

\begin{tabular}{|c|c|c|c|c|c|c|}
\hline Espécies & Subpop. & $\mathrm{n}$ & $\hat{A}$ & $\hat{H}_{o}$ & $\hat{H}_{e}$ & f \\
\hline \multicolumn{7}{|l|}{ Trema micrantha } \\
\hline \multirow[t]{7}{*}{ R.M.S.G } & 1 & 16 & 2,12 & 0,278 & 0,290 & 0,041 \\
\hline & 2 & 12 & 2,00 & 0,498 & 0,380 & $-0,339$ \\
\hline & 3 & 13 & 2,12 & 0,503 & 0,360 & $-0,423$ \\
\hline & 4 & 15 & 2,25 & 0,531 & 0,444 & $-0,205$ \\
\hline & 5 & 12 & 2,25 & 0,484 & 0,438 & $-0,104$ \\
\hline & 6 & 30 & 2,50 & 0,779 & 0,325 & $-0,164$ \\
\hline & Média & & 2,20 & 0,446 & 0,373 & $-0,204$ \\
\hline \multirow[t]{6}{*}{ EEC } & 1 & 7 & 2,12 & 0,437 & 0,378 & $-0,176$ \\
\hline & 2 & 15 & 2,25 & 0,384 & 0,406 & 0,055 \\
\hline & 3 & 8 & 2,25 & 0,366 & 0,388 & 0,059 \\
\hline & 4 & 14 & 2,25 & 0,315 & 0,389 & 0,197 \\
\hline & 5 & 38 & 2,20 & 0,345 & 0,337 & $-0,024$ \\
\hline & Média & & 2,2 & 0,366 & 0,392 & 0,066 \\
\hline \multicolumn{2}{|l|}{ Média geral } & 14,5 & 2,211 & 0,411 & 0,376 & $-0,097$ \\
\hline \multicolumn{7}{|l|}{ Cecropia pachystachya } \\
\hline \multirow[t]{3}{*}{ R.M.S.G } & 1 & 30 & 2,00 & 0,284 & 0,304 & 0,067 \\
\hline & 2 & 30 & 2,43 & 0,461 & 0,439 & $-0,051$ \\
\hline & 3 & 34 & 2,14 & 0,375 & 0,322 & $-0,165$ \\
\hline \multirow{4}{*}{ EEC } & Média & & 2,20 & 0,373 & 0,355 & $-0,052$ \\
\hline & 1 & 44 & 2,43 & 0,250 & 0,295 & 0,153 \\
\hline & 2 & 39 & 2,14 & 0,387 & 0,374 & $-0,034$ \\
\hline & Média & & 2,30 & 0,319 & 0,335 & 0,049 \\
\hline \multicolumn{2}{|l|}{ Média geral } & 32,9 & 2,229 & 0,351 & 0,347 & $-0,013$ \\
\hline
\end{tabular}

RMSG - Reserva Florestal de Santa Genebra

EEC - Estação Ecológica dos Caetetus 


\subsubsection{Estrutura genética}

As estimativas do índice de fixação médio para subpopulações foram pequenas e negativas para ambas espécies pioneiras (-0,090 e -0,006 para T. micrantha e $C$. pachystachya) e, considerando o intervalo de confiança, as estimativas sugerem que as subpopulações se apresentam sob panmixia. No entanto, variações deste parâmetro obtidos nos diferentes locos indicam o oposto, sendo que as estimativas para cinco dos oito locos analisados para T. micrantha e para todos os sete locos em C. pachystachya indicaram desvios de panmixia (estimativas positivas ou negativas maiores do que 5\%) (Tabelas 13 e 14).

O índice de fixação total médio nas populações foi positivo para C. pachystachya e negativo para T. micrantha (0,080 e -0,016, respectivamente), mas as estimativas indicam que suas populações praticamente não armazenam ou armazenam muito pouca endogamia. No entanto, novamente se verifica grande variação nas estimativas entre os locos analisados em ambas espécies. A estimativa média de T. micrantha, que sugere uma única população panmítica, apresenta quatro locos indicando excesso de genótipos homozigotos e outros dois com deficiência destes genótipos.

Já as estimativas médias obtidas para divergência genética entre populações, que foram mínimas para ambas espécies (-0,007 e 0,026 para T. micrantha e $C$. pachystachya, respectivamente) não apresentaram grandes variações entre os locos. Estas estimativas indicam que a maior parte da diversidade genética encontra-se distribuída dentro das populações, sendo um padrão de distribuição normalmente observado para a maioria das espécies arbóreas e com o esperado em espécies alógamas ou de sistema misto de cruzamento, com predomínio de alogamia. 
Tabela 13. Estimativas do coeficiente médio de endogamia dentro das subpopulações ( $f$ ); coeficiente de endogamia total nas populações $(F)$; divergência genética entre populações $\left(\theta_{P}\right)$, e divergência genética entre subpopulações $\left(\theta_{S P}\right)$; obtidas de 11 subpopulações em duas populações naturais Trema micrantha $(\mathrm{N}=178)$, empregando-se 8 locos isoenzimáticos, num total de 20 alelos.

\begin{tabular}{|c|c|c|c|c|}
\hline LOCO & $f$ & F & $\theta_{S P}$ & \\
\hline Mdh-1 & 0,186 & 0,173 & $-0,016$ & 0,000 \\
\hline Gdh-2 & 0,175 & 0,192 & 0,021 & 0,051 \\
\hline Skdh & $-0,360$ & $-0,296$ & 0,047 & 0,002 \\
\hline Nadhdh & 0,063 & 0,272 & 0,222 & $-0,030$ \\
\hline Dia & $-0,041$ & $-0,002$ & 0,037 & $-0,004$ \\
\hline $\mathrm{Mr}$ & $-0,181$ & $-0,102$ & 0,068 & 0,000 \\
\hline Idh & $-0,031$ & $-0,021$ & 0,010 & $-0,006$ \\
\hline Got & $-0,002$ & 0,053 & 0,054 & $-0,019$ \\
\hline $\begin{array}{l}\text { Média } \\
\text { I.C. }\end{array}$ & $\begin{array}{c}-0,090 \\
(-0,201 \text { a } 0,026)\end{array}$ & $\begin{array}{c}-0,016 \\
(-0,139 \text { a } 0,124)\end{array}$ & $\begin{array}{c}0,068 \\
(0,030 \text { a } 0,123)\end{array}$ & $\begin{array}{c}-0,007 \\
(-0,016 \text { a } 0,002)\end{array}$ \\
\hline
\end{tabular}

( ) Estimou-se o intervalo de confiança a 95\% de probabilidade pelo método de reamostragem bootstrap, utilizando-se 1.000 repetições sobre locos.

Da mesma forma, as estimativas para divergência genética entre subpopulações dentro de populações também são baixas (0,068 e 0,086, para T. micrantha e $C$. pachystachya). No entanto, estas estimativas são maiores que aquelas encontradas para divergência entre populações e diferentes de zero, sugerindo que a distribuição espacial agregada em clareiras, ou grupos de indivíduos, é importante para manutenção da diversidade genética nas espécies estudadas. As baixas estimativas de diversidade genética entre populações e subpopulações indicam ocorrência de fluxo gênico entre e dentro de populações. Em T. micrantha uma maior taxa de fluxo é verificada entre populações do que entre subpopulações ( $N_{m}$ de 9,34 e 2,85, respectivamente), não sendo verificado tão grande diferença para $C$. pachystachya $\left(N_{m}\right.$ de 2,36 e 2,12). 
Tabela 14. Estimativas do coeficiente médio de endogamia dentro das subpopulações ( $f$ ); coeficiente de endogamia total nas populações $(F)$; divergência genética entre populações $\left(\theta_{P}\right)$, e divergência genética entre subpopulações $\left(\theta_{S P}\right)$; obtidas de 5 subpopulações em duas populações naturais Cecropia pachystachya $(\mathrm{N}=177)$, empregando-se 7 locos isoenzimáticos, num total de 17 alelos.

\begin{tabular}{lcccc}
\hline Loco & $\hat{f}$ & $\hat{F}$ & $\hat{\theta}_{S P}$ & \\
\hline Pgi-1 & $-0,072$ & $-0,057$ & 0,015 & 0,010 \\
Pgi-3 & 0,298 & 0,321 & 0,032 & 0,009 \\
Idh & 0,213 & 0,306 & 0,118 & 0,047 \\
Mdh-1 & 0,057 & 0,168 & 0,118 & $-0,041$ \\
Mdh-2 & 0,206 & 0,328 & 0,154 & 0,000 \\
Pó-1 & $-0,300$ & $-0,245$ & 0,043 & 0,046 \\
Skdh & $-0,202$ & $-0,078$ & 0,103 & 0,086 \\
& & & & 0,026 \\
Média & $-0,006$ & 0,080 & 0,086 & 0,026 \\
I.C. & $(-0,169$ a 0,164$)$ & $(-0,098$ a 0,254$)$ & $(0,050$ a 0,119$)$ & $(-0,006$ a 0,052$)$ \\
\hline
\end{tabular}

( ) Estimou-se o intervalo de confiança a 95\% de probabilidade pelo método de reamostragem bootstrap, utilizando-se 1.000 repetições sobre locos.

\subsection{Discussão}

Este estudo foi desenvolvido com onze subpopulações de T. micrantha e cinco de C. pachystachya dispostas em dois fragmentos. Os fragmentos são bem distintos quanto à área total e condições de conservação. Por outro lado, o Estado de São Paulo se encontra quase que totalmente desflorestado, restando apenas alguns poucos e pequenos fragmentos, sendo a EEC o segundo maior do interior do Estado e representante da floresta primária original. Sobretudo, percebe-se que existem faixas de vegetação ao longo dos cursos d'água que cortam todo o Estado, bem estreitas e muitas vezes desprezíveis. No entanto, ricas em espécies pioneiras. 
C. pachystachya é comum ao longo das margens de rios e córregos, além de estar presente em grandes grupos de indivíduos, em várzeas esquecidas em propriedades rurais. T. micrantha também é muito comum, não só nas faixas de vegetação ao longo dos cursos d'água, mas também em capoeirões, pastos mal conservados e, até mesmo, nos terrenos baldios nos centros urbanos. Esta espécie, devido sua grande plasticidade em se adaptar aos diferentes tipos de ambientes, tem sido muito utilizada em projetos de revegetação e agrosilvicultura (Carvalho, 1994; Kageyama et al. 2001).

Diante de tão eficiente capacidade de colonização, tornam-se justificáveis as estimativas de diversidade genética verificadas para ambas espécies. Tais estimativas foram altas quando comparadas à média das oito espécies do estágio inicial de sucessão levantadas por Hamrick et al. (1992), bem como para as espécies dos estágios intermediário e avançado ( $\hat{H e}=0,137 ; 0,171$ e 0,182, respectivamente). Da mesma forma, as estimativas foram superiores às médias obtidas para espécies arbóreas de vida curta $(0,111)$, para as populações de espécies arbóreas de vida longa e que dependem do vento para realizar fecundação cruzada $(0,154)$ ou que dependem de animais para dispersar suas sementes $(0,149)$. As estimativas apresentadas por Hamrick \& Loveless (1986), considerando 29 espécies arbóreas comuns na floresta tropical semidecidual na Ilha Barro Colorado, República do Panamá, também foram bem inferiores $(0,111)$. Mas, no trabalho de Loveless \& Hamrick (1987), as médias de diversidade genética para as espécies analisadas $(0,240)$ e para Soroceae affinis $(0,239)$, que é polinizada pelo vento e tem sementes dispersas por animais, já não foram tão inferiores.

As taxas de heterozigosidade observadas nas populações da RMSG, superiores às esperadas sob as condições de E.H.W., sugerem que estas espécies estão bem adaptadas aos ambientes alterados. T. micrantha, principalmente, observada com elevadíssima heterozigosidade e negativo coeficiente de endogamia intrapopulacional, expõe sua habilidade de manter diversidade genética em condição de natureza antropizada. Sua ocorrência, sobretudo, depende de agentes dispersores de sementes e da ação de fluxo gênico dentro e entre populações mantidas sob as mais diferentes condições. Elas possuem sistema de polinização dependente de ventos, mas contam com animais para dispersar suas sementes por médias e longas distâncias. Aves e morcegos são atraídos 
pelas infrutescências maduras da C. pachystachya, enquanto os frutos de $T$. micrantha são muito procurados por aves e primatas. Segundo Santos (1994), os morcegos têm grande facilidade para voar em ambientes abertos e, estudando suas habilidades em dispersar pólen de Bauhynia forficata, verificou-se vôos noturnos ao longo de quase cinco quilômetros, sendo bastante freqüentes entre fragmentos. Já Janzen (1980) cita que polinizadores vertebrados podem viajar quilômetros entre plantas da mesma espécie, sendo que morcegos voam 3 a 16 quilômetros numa noite em busca de alimentos.

Os resultados encontrados para T. micrantha e C. pachystachya indicaram, portanto, eficiente fluxo gênico entre populações e dentro das mesmas, sendo o suficiente para manter alta diversidade genética nas espécies e estreita relação genética, mesmo entre populações distanciadas por mais de $200 \mathrm{~km}$. Sobretudo, as estimativas também indicam desvios da panmixia e que a estruturação espacial de forma agregada é favorável para manutenção da diversidade genética nestas espécies.

As estimativas da divergência genética entre subpopulações maiores que entre populações sugerem que a dispersão de pólen pelo vento ocorre de forma mais restrita aos pequenos grupos dentro de clareiras. Mesmo existindo esta tendência de estruturação genética espacial nas respectivas subpopulações, a divergência entre clareiras próximas sugere um processo de seleção microambiental com favorecimento de múltiplos genótipos atuando dentro de cada clareira.

A partir das estimativas de diversidade genética obtidas, acredita-se que as espécies pioneiras estudadas podem se manter, sem prejuízos genéticos a curto prazo, sob condições de paisagem antropizada. Na RMSG, que representa uma vegetação bastante alterada, existe diferença significativa entre as estimativas de heterozigosidade observada e esperada, obtidas para $T$. micrantha $\left(\hat{H}_{o}\right.$ de o,446 e $\hat{H e}$ de 0,373$)$, causada por excesso de heterozigotos. Da mesma forma, diferenças entre as estimativas de heterozigosidade observada, comparativamente entre os dois fragmentos, para ambas espécies ( $\hat{H}_{o}$ de 0,446 e 0,366 para T. micrantha; 0,373 e 0,319 para C. pachystachya, para RMSG e EEC, respectivamente), também revelam maior freqüência de heterozigotos nas populações amostradas no fragmento mais alterado. Porém, não se observou a mesma magnitude nas diferenças verificadas entre as estimativas de 
heterozigosidade esperada sob condições de E.H.W. ( $\hat{H e}$ de 0,373 e 0,392 para T. micrantha; 0,355 e 0,335 para C. pachystachya).

Diante desta situação, um processo de seleção em favor dos indivíduos mais heterozigóticos está atuando nas espécies estudadas, porém, de uma forma mais severa na população de $T$. micrantha, localizada na RMSG. As maiores proporções de heterozigotos mantidas nas subpopulações, pode ser devido à condição de alta competição dentro das clareiras. Resultados sob o mesmo foco de discussão foram encontrados por Epperson \& Alvarez-Buylla (1997). Os autores estudaram populações de Cecropia obtusifolia comparativamente entre diferentes estágios de vida, quando seus resultados evidenciaram seleção microambiental pelo favorecimento de múltiplos genótipos dentro de uma dada clareira, além de também terem verificado menores estimativas para divergência genética entre populações mais distantes entre si.

Segundo Wright (1931), a fragmentação aumenta a divergência genética interpopulacional quando a estrutura populacional é estável e o tamanho da população e fluxo génico correspondem a $\mathrm{N}_{\mathrm{em}}<1$. No entanto, quando a estrutura populacional é instável, a divergência genética depende da freqüência de eventos de colonização e extinção e do número de fontes de colonisadores (Wade \& McCauley, 1998; Land, 1992; Whitlock, 1992). Dessa forma, como citado por Young e Boyle (2001), se a taxa de extinção e colonização for mais que o dobro da taxa de migração, pode ocorrer substancial redução da variância genética entre subpopulações. Por outro lado, para Slatkin (1987) seria necessário o fluxo gênico de quatro migrantes por geração entre populações para se prevenir o efeito de deriva genética sobre a diferenciação genética local e, portanto, a divergência entre populações. Nossas estimativas indiretas de fluxo gênico entre populações e subpopulações não superam tal valor, com exceção para o fluxo estimado entre populações de T. micrantha.

Para Loveless (1992), o número médio de migrantes trocados entre populações locais será baixo se a espécie tiver populações muito isoladas. Mas pode acontecer de serem obtidas estimativas de fluxo gênico satisfatórias entre populações aparentemente distanciadas por recentes alterações do uso da terra. Desta forma, as estimativas de migração de genes e diversidade genética estariam indicando uma contínua distribuição 
da espécie num passado recente. Tal possibilidade foi explicada por aquele autor, afirmando que as medidas indiretas de fluxo gênico refletem taxas históricas de fluxo gênico para a distribuição atual da diversidade genética, e não representam o padrão de fluxo gênico em um determinado ano ou única geração.

As espécies em questão são mais facilmente encontradas em florestas secundárias e ao longo de paisagens fragmentadas do que dentro das florestas primárias. Tal possibilidade de adaptação às condições de fragmentação está provavelmente associada à eficiência de fluxo gênico e diretamente dependente da existência de agentes dispersores. As estimativas de fluxo gênico dentro das populações das espécies pioneiras estudadas são menores do que aquelas obtidas entre as populações. Provavelmente, tal fato está associado às diferentes características de forrageamento entre seus agentes dispersores. O fluxo gênico via pólen não é muito eficiente ficando mais restrito às clareiras. No entanto, estudos para espécies anemófilas já demonstraram que grãos de pólen podem percorrer maiores distâncias, como para uma espécie de pinus em que constataram distância de dispersão de até $500 \mathrm{~m}$, garantindo grande freqüência de migração entre populações (Hamrick, 1989). Pássaros são dispersores para ambas espécies e morcegos apenas para C. pachystachya. Alvarez-Buylla e Martínez-Ramos (1990) verificaram que a maioria das sementes de C. obtusifolia caíam a poucos metros da planta mãe, mas também foram encontradas sementes distantes $500 \mathrm{~m}$ da mesma.

Como já verificado em alguns estudos, até mesmo as solitárias árvores remanescentes deixadas nos pastos podem exercer considerável influência no nível de fluxo gênico entre populações fragmentadas (Chase et al. 1996; Aldrich \& Hamrick, 1998). Tais árvores podem servir como trampolins para migração gênica entre populações, participando diretamente na troca de pólens entre as populações nos fragmentos ou agindo como um corredor para movimentação de polinizadores e dispersores. Também as estimativas obtidas para T. micrantha e C. pachystachya sugerem que suas populações distribuídas em paisagens fragmentadas e os indivíduos remanescentes em pastos e ao longo de matas ciliares são cruciais na manutenção da coesão genética entre populações após a fragmentação. Desta forma, diante da maior freqüência de indivíduos nas formações florestais secundárias, da posição de eficientes 
colinizadoras em áreas abandonadas, bordas de fragmentos e outras condições comuns em paisagens antropizadas, a diversidade genética dessas espécies pode ser mantida facilmente nas populações sob fragmentação.

\subsection{Conclusões}

As espécies pioneiras arbóreas Trema micrantha e Cecropia pachystachya apresentam alta diversidade genética em suas populações.

O fluxo gênico entre e dentro das populações é realizado de forma a garantir maior diversidade dentro do que entre populações. No entanto, a divergência genética verificada entre suas subpopulações distantes por 200 m é maior do que entre as populações distantes por $200 \mathrm{~km}$. Tal resultado sugere que a disposição de indivíduos em clareiras é favorável para manutenção da alta diversidade genética nas espécies.

Ambas espécies pioneiras estudadas podem se manter, sem prejuízos genéticos a curto prazo, sob condições de paisagens antropizadas. Tal habilidade está associada a uma alta competição dentro das clareiras resultando em um processo de seleção em favor da manutenção de maiores proporções de heterozigotos. 


\section{ESTRUTURA GENÉTICA EM DIFERENTES ESTÁDIOS DE VIDA EM UMA POPULAÇÃO DE Trema micrantha (L.)B.}

\section{Resumo}

Espécies do primeiro estágio sucessional possuem características gênicas e ecológicas próprias resultantes da existência de banco de sementes e da longa distância de dispersão de suas sementes. Este trabalho visou quantificar e comparar a distribuição da diversidade genética presente nos diferentes estádios de vida (sementes do solo, progênies e plantas do dossel) em uma população natural da espécie pioneira Trema micrantha (Ulmaceae), avaliando o banco de sementes como um potencial tampão gênico para a espécie. Amostrou-se folhas de 69 plantas do dossel, de plântulas de 10 progênies, além de 100 plântulas obtidas a partir do banco de sementes do solo. A coleta de solo foi realizada em cinco clareiras, das quais foram amostradas as plantas do dossel, escolhidas ao acaso na Reserva Florestal Mata de Santa Genebra, um fragmento com 252 ha de floresta tropical semidecídua, no município de Campinas-SP. A diversidade genética foi avaliada por polimorfismo isoenzimático, a partir de eletroforese em sistema horizontal e gel a $13 \%$ de penetrose e amido. Os resultados revelaram alta diversidade genética na população. As estimativas para o índice de fixação e divergência genética entre subpopulações obtidas nos diferentes estádios de vida sugerem significativas proporções de cruzamentos endogâmicos, acirrada competição nas etapas de germinação e desenvolvimento das plântulas favorecendo a seleção aumentando a proporção de heterozigotos e importante participação dos agentes dispersores de sementes na realização do fluxo gênico intrapopulacional. 


\section{Summary}

[Genetic structure in different life stages in a population of Trema micrantha (L.)B.] Species of the first successional level present genetical and ecological characteristics resultant from the seed bank existence and from the long distance dispersal of its seeds. This work aimed to quantify and to compare the genetic diversity distribution in the different life stages (soil seeds, progeny and adults plants from the dossel) in a natural population of the tropical pioneer tree Trema micrantha (Ulmaceae), evaluating the seed bank as a potential genetic buffer for this species. Leaves of 69 plants and of seedlings of 10 progenies, and from 100 seedlings from the soil seeds were sampled. The soil collection was performed in five natural gaps in the Reserva Florestal de Santa Genebra, a fragment with 252 ha of decidual tropical forest, in Campinas, São Paulo State-Brazil. The genetic diversity was evaluated for allozyme variation, from horizontal electrophoresis and 13\% penetrose and starch gels. The results revealed high genetic diversity in the population. The fixation indices and the genetic differentiation estimates among subpopulations obtained in the different life stages suggested significant proportions of inbreeding in the mating system, competition during seed germination

and seedling development with selection favoring heterozygosity and important participation of the seed dispersor agents in the achievement of the intrapopulation gene flow.

\subsection{Introdução}

Espécies do primeiro estágio sucessional, conhecidas como pioneiras, são consideradas possuidoras de características próprias de extinção local e recolonização, podendo resultar no aumento do fluxo gênico e redução da diferenciação genética entre populações (Slatkin, 1985, 1987). A existência de banco de sementes e a longa distância de dispersão de pólen e sementes apresentam importantes conseqüências genéticas e ecológicas para estas espécies. Exemplos destas são a possibilidade do banco de semente 
agir como tampão gênico, sendo capaz de repor a diversidade genética perdida pela população do dossel, fazendo a dispersão de sementes e pólen reduzir a distância genética entre populações geograficamente distantes (Alvarez-Buylla \& Garay, 1994). Estudos teóricos resultaram em modelos primeiramente desenvolvidos para espécies anuais e poucos estudos empíricos comparam a estrutura genética de bancos de sementes com outros estádios de vida (Tonsor et al. 1993; Alvarez-Buylla \& Garay, 1994; Alvarez-Buylla et al. 1996).

O banco de sementes é caracterizado como a quantidade de sementes existente numa determinada área de solo, num dado momento. Ele é entendido como um sistema dinâmico, com entrada de sementes via dispersão e chuva de sementes e saída por predação, doenças ou germinação. O balanço entre estes processos é que determina a taxa de renovação do banco de sementes num determinado local (Hyatt \& Casper, 2000).

Funções ecológicas têm sido propostas para as sementes sobreviventes por longos períodos no banco de sementes. Elas podem agir como uma reserva de propágulos, tornando o banco de sementes com potencial para reduzir a probabilidade de extinção de populações (Cohen, 1966; Venable \& Brown, 1988). Como o banco de sementes contém alelos que podem estar presentes em diferentes freqüências em relação à população sobre o solo, o banco de sementes pode retardar a taxa de evolução ou mudar a estrutura genética da população de plantas do dossel (Levin, 1990). Característico de espécies especializadas em clareiras, o banco de sementes pode facilitar a coexistência de espécies potencialmente competitivas (Pake \& Venable, 1995). Finalmente, ele pode perfeitamente ser o principal recurso da comunidade de plantas seguindo mudanças ambientais, tais como queda de árvores, restauração de área alterada e mesmo queimadas, todos com potencial para acionar a germinação de sementes dormentes (Hyatt \& Casper, 2000). Sobretudo, tais funções dependem da persistência das sementes no solo.

Dessa forma, estreitas relações parecem existir entre o banco de sementes no solo e a evolução e dinâmica genética da população de plantas da mesma espécie. No entanto, muitas questões ainda permanecem sem respostas. Percebe-se que a similaridade genética do banco de sementes com a população de plantas do dossel 
depende de uma complexa relação entre o sistema reprodutivo, distância de dispersão de sementes, padrão espacial e temporal de seleção, variação na sobrevivência e fecundidade. Estes são fatores que afetam a longevidade das sementes nos bancos de sementes e da proporção de mudas resultantes da germinação de sementes do banco persistente no solo em relação àquelas originadas do último evento reprodutivo (Tonsor et al. 1993).

Obviamente, o entendimento das mudanças entre as populações do banco de sementes e das plantas reprodutivas depende de um vasto conjunto de informações ecológicas e genéticas sobre a espécie de interesse. O conhecimento da distribuição da diversidade genética, ao longo de diferentes estádios de vida na mesma população, torna-se muito útil para o entendimento das forças evolucinárias na estruturação genética da espécie. Considerando modelos de simulação, a dispersão das sementes diminui a estrutura genética espacial encontrada entre as plantas produtoras das sementes (Rohlf \& Schnell, 1971; Turner et al. 1982). No entanto, é necessário considerar que o mecanismo de polinização, a densidade de adultos, a presença do banco de sementes e a seleção microambiental também participam da estruturação genética populacional, devendo ser diferente para diferentes espécies de plantas.

Sob esse aspecto, realizando-se a amostragem em clareiras e obtendo-se as estimativas dos parâmetros de diversidade genética intra e interpopulacional para diferentes estádios de vida, espera-se que a importância da dispersão de sementes para a espécie se manifeste através da diminuição da diversidade genética interpopulacional estimada para sementes do banco em relação às progênies e plantas do dossel. Por outro lado, a permanência de semente no banco de solo, por sucessivos eventos reprodutivos, também podem ser responsáveis pela diminuição da estrutura genética espacial no banco de sementes. Se existir um favorecimento de genótipos em diferentes clareiras (seleção microambiental), espera-se obter estimativa interpopulacional maior para a população do dossel em relação ao banco de sementes do solo. Além disso, se genótipos heterozigotos trouxerem vantagens competitivas serão verificados menores níveis de endogamia na população de plantas do dossel. 
Diante de tais considerações, este trabalho foi desenvolvido com o objetivo de quantificar e entender a estruturação genética na população de plantas amostradas no dossel da floresta, na população de progênies e também na população de sementes presente no banco de solo, para a espécie pioneira Trema micrantha. A diversidade genética foi avaliada através do polimorfismo de isoenzimas e os resultados foram avaliados quanto a influência dos agentes dispersores, da demografia associada às clareiras e quanto a participação do banco de sementes na manutenção da diversidade genética na população.

\subsection{Material e métodos}

\subsubsection{Espécie estudada}

Neste estudo, foram amostradas subpopulações da espécie pioneira Trema micrantha (L.)B., Ulmaceae. Esta espécie ocorre em praticamente todos os tipos de formações florestais e é uma das primeiras espécies a se estabelecer em clareiras e áreas abandonadas, a partir do banco de sementes do solo (Lorenzi, 1992; Durigan et al. 2002). Está presente entre as latitudes $30^{\circ} \mathrm{N}$ (Estados Unidos) e $30^{\circ} \mathrm{S}$ (Brasil) e é classificada como hermafrodita críptica por possuir indivíduos variando de monóicos a dióicos (Torres, 1996). Suas flores são unissexuais ou bissexuais andrógenas, polinizadas principalmente pelo vento e a dispersão das suas sementes é por zoocoria, envolvendo grande diversidade de aves (Carvalho, 1994).

\subsubsection{Locais de estudo}

A amostragem foi realizada na Reserva Florestal Mata de Santa Genebra (RMSG), a qual possui 251,8 ha de floresta tropical estacional semidecídua (IBGE, 1993), localizada nas coordenadas $22^{\circ}$ 49’ S e $47^{\circ}$ 06’ W, no município de CampinasSP. Ao longo de sua área levemente ondulada, com altitudes variando de 580 a 610 m, 
verifica-se um mosaico de vegetação em que várias fases sucessionais são encontradas. Ocorrem tanto áreas com floresta preservada, formando um dossel contínuo de 15 a 18 metros de altura com espécies emergentes de até $25 \mathrm{~m}$, como áreas muito perturbadas ocupadas por espécies de estágio sucessional inicial (Leitão-Filho, 1995). Neste fragmento, além dos processos naturais que estimulam a regeneração, ocorreram perturbações antrópicas como queimadas, extração seletiva de madeiras e retirada de lenha.

\subsubsection{Amostragem}

\section{Banco de sementes do solo}

Na RMSG, foram localizadas cinco áreas onde se observaram plantas de $T$. micrantha. Dentre as áreas, três corresponderam a grandes clareiras abertas provavelmente por retirada de madeira e ocorrência de incêndio. As outras duas coincidem com áreas menos perturbadas, com vegetação arbustiva predominante e as clareiras se devem à abertura de estreitas estradas de acesso.

Foram coletadas 100 amostras da camada superior do solo $(50 \times 50 \mathrm{~cm}$, com $5 \mathrm{~cm}$ de profundidade) em janeiro de 2001, utilizando-se um gabarito de madeira nas dimensões desejadas $\left(0,25 \mathrm{~m}^{2}\right)$. Considerando a camada de liteira, as amostras foram coletadas ao acaso, sendo vinte pontos de coleta para representar cada uma das cinco referidas áreas deste fragmento. O solo amostrado foi acondicionado em sacos de polietileno com identificação referente e transportado para o viveiro de espécies florestais do IPEF, em Piracicaba, ESALQ/USP. O solo foi distribuído aleatoriamente em esquadria de madeira constituindo canteiros, onde foi monitorado e irrigado diariamente. Os canteiros foram montados sobre lona plástica preta, de forma que cada amostra do solo foi transferida para um espaço com as mesmas dimensões.

Todas as 1054 plântulas de T. micrantha que regeneraram do banco foram envolvidas em papel alumínio, identificadas quanto ao quadrante referente, imersas em nitrogênio líquido e levadas para armazenamento em freezer a $80^{\circ} \mathrm{C}$ negativos. 
Armazenadas desta forma, 100 plântulas, sendo 20 obtidas ao acaso dentro das cinco clareiras, foram utilizadas para as análises em laboratório.

\section{Plantas do dossel}

Foram coletadas folhas jovens de 69 plantas de T. micrantha existentes naquelas mesmas clareiras e transportadas para análise genética em laboratório. As amostras permaneceram em caixa de isopor contendo gelo e foram processadas no Laboratório de Genética e Reprodução de Espécies Arbóreas (LARGEA), na ESALQ/USP, Piracicaba S.P.

\section{Progênies}

Frutos de T. micrantha foram coletados de 10 árvores individualmente e levados ao laboratório de sementes de espécies florestais do Depto. de Ciências Florestais, ESALQ-USP, onde foram lavados com auxílio de uma peneira. As sementes (diásporos) receberam tratamento para acelerar a germinação (Torres, 1996), foram dispostas sobre papel de germinação, dentro de caixas de gerbox e mantidas em germinador. Em germinador, foram submetidas às condições de fototropismo com 8 horas de escuro e 16 de luz, e à temperatura alternada de $30^{\circ} \mathrm{C}$ sob luz e $20^{\circ} \mathrm{C}$ quando em escuro. As plântulas foram repicadas para substrato e transferidas para casa de vegetação, onde foram mantidas até as análises de isoenzimas. A população de progênies foi representada por dez progênies, com dez indivíduos cada.

\subsubsection{Protocolos}

Previamente à aplicação da técnica de eletroforese horizontal de isoenzimas, testou-se quatro sistemas tampão gel/eletrodo, combinados com 32 sistemas enzimáticos, para as plântulas e também para as plantas do dossel. Durante a extração, 
utilizou-se o tampão 1 citado em Alfenas et al. (1991). Todo o procedimento utilizado durante a aplicação da técnica seguiu as indicações dos mesmos autores.

Feita a seleção, as enzimas foram extraídas das plântulas de T. micrantha referentes às progênies e banco de sementes, e submetidas para revelação da glutamato oxaloacetato transaminase (GOT, EC-2.6.1.1), diaforase (DIA, EC-1.8.1.4), glucose-6fosfodesidrogenase (G6PDH-1.1.1.49), isocitrato desidrogenase (IDH, EC-1.1.1.42), glucose desidrogenase (GDH, EC-1.1.1.47), malato desidrogenase (MDH, EC-1.1.1.37), xiquimato desidrogease (SKDH, EC-1.1.1.25) e fosfogluco isomerase (PGI, EC-5.3.1.9). Durante a eletroforese, as enzimas IDH, GDH, MDH e SKDH apresentaram melhor padrão de revelação e resolução sob o sistema tampão gel/eletrodo desenvolvido por Clayton \& Tretiak (1972), que é citado com algumas modificações em Alfenas et al. (1991), como sistema 8. Para as outras enzimas (GOT, G6PDH, DIA e PGI), optou-se

pelo sistema tampão gel/eletrodo desenvolvido por Hakim-Elabi (1980), citado por aqueles autores como sistema 25. Da interpretação dos zimogramas, obteve-se genótipos a partir de nove locos isoenzimáticos polimórficos, somando-se 20 alelos.

Para as plantas do dossel, revelou-se as enzimas malato desidrogenase (MDH, EC-1.1.1.37), glucose desidrogenase (GDH, EC-1.1.1.47), xiquimato desidrogease (SKDH, EC-1.1.1.25), NADH-desidrogenase (NADHDH, EC-1.6.99.3), diaforase (DIA, EC-1.8.1.4), menadiona redutase (MR, EC-1.6.99.2), isocitrato desidrogenase (IDH, EC1.1.1.42) e glutamato oxaloacetato transaminase (GOT, EC-2.6.1.1). A eletroforese foi realizada sob o sistema tampão gel/eletrodo número 25, citado em Alfenas et al. (1991). Nesta etapa, somaram-se oito locos polimórficos, num total de 20 alelos.

\subsubsection{Análises estatísticas}

A caracterização da diversidade genética existente nas clareiras foi realizada baseando-se nos genótipos dos locos polimórficos para cada um dos três estádios de ciclo de vida amostrados. Os parâmetros de diversidade genética intrapopulacional utilizados foram: proporção de alelos por locos polimórficos (A), heterozigosidade 
esperada sob condições de Equilíbrio de Hardy-Weiberg $\left(\mathrm{H}_{\mathrm{e}}\right)$, heterozigosidade observada $\left(\mathrm{H}_{\mathrm{o}}\right)$ e o coeficiente de endogamia intrapopulacional (f).

A estrutura genética foi estudada pela análise da variância das freqüências gênicas (Weir, 1996) quando se considerou as cinco clareiras dentro da RMSG como populações. Os parâmetros estimados foram: índice de fixação médio (f); coeficiente de endogamia total $(F)$ e divergência genética entre populações $\left(\theta_{\mathrm{p}}\right)$. Para verificar se as estimativas médias destes parâmetros eram diferentes de zero, estimou-se o intervalo de confiança a 95\% de probabilidade pelo método de reamostragem bootstrap, utilizando-se 1.000 repetições sobre locos. As análises de variância descritas acima, os bootstraps, bem como as estimativas de diversidade genética intrapopulacional, foram obtidos com o auxílio do programa GDA de Lewis \& Zaykin (1999).

\subsubsection{Comparações entre estádios de vida}

Baseando-se na caracterização genética realizada para populações de plantas do dossel, progênies e de sementes do banco do solo, comparou-se a diversidade genética existente e sua distribuição nos três estádios de vida. Além disto, analisou-se a distribuição das freqüências alélicas nos locos para verificar a existência de diferenças significativas entre as populações destes estádios. Para tanto, utilizou-se apenas os seis locos isoenzimáticos comuns aos diferentes estágios, sendo eles: Got, Dia-2, Idh, Gdh-2, Mdh-2 e Skdh, os quais somam 15 alelos.

O teste para verificar a existência de diferenças nas freqüências alélicas entre as populações dos diferentes estádios de vida (plantas do dossel, plântulas do solo e de progênies) foi realizado através do programa TFPGA, desenvolvido por Miller (1997). Realizou-se comparações entre as populações e se testou a hipótese de que a distribuição dos alelos é idêntica nas gerações. A metodologia utilizada para a análise foi descrita por Raymond \& Rousset (1995) e o procedimento assume que os dados provenientes de cada loco são independentes entre si. Foram utilizadas 10 baterias de testes, com 2.000 permutações por bateria, quando se realizou comparações entre as populações dos diferentes estádios de vida. 


\subsection{Resultados}

Como se pode observar na Tabela 15, ocorrem variações nas freqüências alélicas dos locos analisados entre os estádios de vida. Para a Got apenas o alelo $\underline{c}$ não ocorre nos três estádios de vida amostrados, estando presente apenas nas progênies produzidas no período. Neste loco, o alelo $\underline{b}$ é bastante freqüente nas progênies enquanto é o alelo $\underline{\mathrm{a}}$ o mais freqüente na população do dossel e no banco de sementes.

Variações nas freqüências de alelos entre estádios de vida também ocorrem para Skdh e Mdh-2. Ambos locos tiveram o alelo a mais freqüente nas progênies enquanto o alelo $\underline{b}$ foi mais freqüente no banco e nas plantas do dossel. Por outro lado, os alelos mais freqüentes coincidiram nos locos Dia-2, Idh e Gdh-2.

As variações nas estimativas de diversidade e sua distribuição verificada entre as populações de T. micrantha nos diferentes estádios de vida, também podem ser observadas nos resultados do teste de diferenciação de freqüências alélicas (Tabela 16). Verifica-se que 44\% das comparações indicaram haver algumas semelhanças nas freqüências alélicas nos diferentes locos (probabilidades maiores que 5\%), estando os extremos nos locos Gdh-2 e Mdh-2, podendo ser confirmados pela distribuição das freqüências alélicas apresentada na tabela 15. Sobretudo, as estimativas dos testes quiquadrado (grau de liberdade igual a 12 e 95\% de probabilidade) rejeitam a existência de igualdade na distribuição das freqüências alélicas entre as populações nos diferentes estádios de vida.

Mesmo verificando as grandes diferenças que existem nas freqüências alélicas entre as populações, a estatística resultante da comparação da população do banco com a população de plantas do dossel foi menor que as obtidas para ambas as outras. Esta observação salienta que a diversidade da população de plantas do dossel está melhor representada pela população existente na forma de banco de sementes do solo do que aquela presente nas progênies da espécie estudada. 
Tabela 15. Freqüências alélicas nas populações de plantas do dossel, progênies e do banco de sementes do solo de Trema micrantha, localizadas na RMSG.

\begin{tabular}{|c|c|c|c|c|}
\hline Locos & Alelos & Dossel (59) & Progênies (83) & Banco (84) \\
\hline \multirow[t]{3}{*}{ Got } & a & 0,637 & 0,091 & 0,652 \\
\hline & $\mathrm{b}$ & 0,363 & 0,719 & 0,348 \\
\hline & c & 0,000 & 0,189 & 0,000 \\
\hline \multirow[t]{3}{*}{ Dia-2 } & $\mathrm{a}$ & 0,405 & 0,268 & 0,326 \\
\hline & $\mathrm{b}$ & 0,349 & 0,708 & 0,623 \\
\hline & c & 0,246 & 0,024 & 0,050 \\
\hline \multirow[t]{2}{*}{ Idh } & $\mathrm{a}$ & 0,177 & 0,149 & 0,193 \\
\hline & $\mathrm{b}$ & 0,823 & 0,851 & 0,807 \\
\hline \multirow[t]{2}{*}{ Gdh-2 } & a & 0,934 & 0,940 & 0,910 \\
\hline & $\mathrm{b}$ & 0,066 & 0,060 & 0,090 \\
\hline \multirow[t]{3}{*}{ Mdh-2 } & $\mathrm{a}$ & 0,008 & 0,798 & 0,276 \\
\hline & $\mathrm{b}$ & 0,946 & 0,143 & 0,693 \\
\hline & c & 0,046 & 0,059 & 0,031 \\
\hline \multirow[t]{2}{*}{ Skdh } & $\mathrm{a}$ & 0,388 & 0,747 & 0,392 \\
\hline & $\mathrm{b}$ & 0,612 & 0,253 & 0,608 \\
\hline
\end{tabular}

( ) Tamanho total da amostra

As estimativas de diversidade genética intrapopulacional (Tabela 17) variaram entre os diferentes estádios de vida, sendo que as menores proporções de heterozigosidade se referem à população de progênies $(0,218$ e 0,263 para heterozigosidade esperada e observada, respectivamente). As mesmas estimativas foram próximas entre a população de plantas do dossel $(0,351$ e 0,420) e a de sementes do solo $(0,394$ e 0,404$)$. As estimativas de heterozigosidade observadas foram superiores às esperadas nos três estádios de ciclo de vida, tendo sido obtidos índice de fixação negativos para ambos estádios $(-0,205,-0,225$ e $-0,027$, respectivamente para a população de plantas do dossel, progênies e do banco de sementes). 
Considerando os parâmetros de estruturação genética (Tabela 18), observa-se que as estimativas do índice de fixação intrapopulacional prevalecem negativas nas subpopulações dos três estádios de vida (-0,186, -0,231 e -0,020, respectivamente para plantas do dossel, progênies e banco), mas apenas o intervalo de confiança definido para progênies confirma desvios significativos. Da mesma forma, a endogamia total na população de progênies é significativamente diferente de zero e bem maior do que as estimativas obtidas para as populações de plantas do dossel e do banco $(0,249,-0,140$ e 0,026, respectivamente).

Tabela 16. Testes de diferenciação de freqüências alélicas entre populações representativas do banco de solo, progênies e plantas do dossel de Trema micrantha.

\begin{tabular}{|c|c|c|c|c|c|c|}
\hline \multirow[b]{2}{*}{ Locos } & \multicolumn{2}{|c|}{ Banco versos Progênies } & \multicolumn{2}{|c|}{ Banco versos Dossel } & \multicolumn{2}{|c|}{ Progênies versos Dossel } \\
\hline & Probabilidade & erro padrão & Probabilidade & Erro padrão & Probabilidade & erro padrão \\
\hline Got & 0,0000 & 0,0000 & 0,3129 & 0,0220 & 0,0000 & 0,0000 \\
\hline Dia-2 & 0,1736 & 0,0147 & 0,0000 & 0,0000 & 0,0000 & 0,0000 \\
\hline Idh & 0,4844 & 0,0153 & 0,5211 & 0,0164 & 0,4980 & 0,0094 \\
\hline Gdh-2 & 0,3583 & 0,0109 & 0,6330 & 0,0050 & 0,8064 & 0,0046 \\
\hline Mdh-2 & 0,0000 & 0,0000 & 0,0000 & 0,0000 & 0,0000 & 0,0000 \\
\hline Skdh & 0,0000 & 0,0000 & 1,0000 & 0,0000 & 0,0000 & 0,0000 \\
\hline \multicolumn{2}{|c|}{ Probabilidade média } & 0,0000 & & 0,0000 & & 0,0000 \\
\hline GL & & 12 & & 12 & & 12 \\
\hline $\mathrm{X}$-sq & & $66,4254 * *$ & & $44,1560 * *$ & & $81,0529 * *$ \\
\hline
\end{tabular}

** significativo a $1 \%$ de probabilidade e 12 graus de liberdade 
Tabela 17. Tamanho da amostra, estimativas médias de heterozigosidade esperada e observada e índice de fixação obtidos entre as subpopulações de plantas do dossel, progênies e o banco de sementes do solo de Trema micrantha, localizadas na RMSG.

\begin{tabular}{cccc}
\hline & Dossel & Progênies & Banco \\
\hline$N$ & & & \\
$\hat{H}_{o}$ & $69(5)$ & $90(9)$ & $100(5)$ \\
$\hat{H}_{e}$ & 0,420 & 0,263 & 0,404 \\
$\hat{f}$ & 0,351 & 0,218 & 0,394 \\
& $-0,205$ & $-0,225$ & $-0,027$ \\
\hline
\end{tabular}

( ) número de subpopulações consideradas na análise

Tabela 18. Índice de fixação médio, índice de fixação total na população e diversidade genética entre subpopulações das populações representando as plantas do dossel, progênies e o banco de sementes do solo de Trema micrantha, localizadas na RMSG.

\begin{tabular}{cccc}
\hline & Dossel & Progênies & Banco \\
\hline$\hat{f}$ & & & \\
& $-0,186$ & $-0,231$ & $-0,020$ \\
$\hat{F}$ & $(-0,441$ a 0,078$)$ & $(-0,298$ a $-0,130)$ & $(-0,163$ a 0,138$)$ \\
& $-0,140$ & 0,249 & 0,026 \\
$\theta_{P}$ & $(-0,321$ a 0,087$)$ & $(0,146$ a 0,348$)$ & $(-0,060$ a 0,144$)$ \\
& 0,039 & 0,384 & 0,045 \\
& $(-0,010$ a 0,084$)$ & $(0,326$ a 0,446$)$ & $(0,005$ a 0,091$)$ \\
\hline
\end{tabular}

( ) intervalo de confiança a 95\% de probabilidade e 1.000 bootstraps sobre subpopulações 
Quanto a diversidade genética entre as subpopulações, as estimativas indicaram divergência genética insignificante no estádio de plantas do dossel e significativamente diferente de zero para as sementes do solo (0,039 e 0,045, respectivamente). Já a divergência verificada entre progênies está acima da esperada entre progênies de irmãos completos $(0,384)$.

Estimativas de diversidade genética são apresentadas para cada subpopulação da população do dossel (Tabela 19). Verifica-se que é mantida alta diversidade genética nas subpopulações e as estimativas do índice de fixação intrapopulacional são negativos e elevados para quatro das cinco subpopulações, sendo que as estimativas variaram de 0,023 a -0,442. Desta forma, apenas a subpopulação um não apresenta excesso de heterozigotos em seus locos.

Na Tabela 20, estão apresentadas as estimativas dos parâmetros de estruturação genética, estimados para cada loco da população do dossel. As estimativas variaram bastante entre locos. $\mathrm{O}$ índice de fixação intrapopulacional variou de 0,226 a -0,697 para os locos Gdh-2 e Skdh, respectivamente. Para os mesmos locos, as estimativas do índice de fixação total para população foram de 0,192 e -0,500. Ambos índices de fixação apresentaram estimativas médias negativas para a população, indicando excesso de heterozigotos. No entanto, comparando-se com os intervalos de confiança, estas estimativas não são diferentes de zero. Quanto à divergência genética obtidas para locos, apenas o Skdh resultou em estimativa elevada $(0,116)$.

As estimativas dos mesmos parâmetros para a população do banco de sementes do solo estão apresentadas nas Tabelas 21 e 22. Elas apresentam variação entre as subpopulações e também entre os locos. As estimativas médias dos parâmetros de estruturação genética obtida para população foram bem próximas de zero.

Por outro lado, as estimativas de diversidade genética obtidas individualmente para as progênies, indicam excesso de heterozigotos em todos locos (Tabelas 23 e 34). O índice de fixação intrapopulacional também resultou em estimativas negativas e diferentes de zero para os sete locos analisados. 
Tabela 19. Estimativas dos parâmetros de diversidade genética intrapopulacional obtidas para cada subpopulação de Trema micrantha amostrada no dossel da RMSG.

\begin{tabular}{ccccc}
\hline Subpopulação & $\mathrm{N}$ & $\hat{H}_{e}$ & $\hat{H}_{o}$ & $\hat{f}$ \\
\hline 1 & 15 & 0,315 & 0,308 & 0,023 \\
2 & 7 & 0,341 & 0,442 & $-0,323$ \\
3 & 12 & 0,321 & 0,455 & $-0,442$ \\
4 & 14 & 0,395 & 0,477 & $-0,216$ \\
5 & 9 & 0,382 & 0,418 & $-0,087$ \\
Média & 11,83 & 0,351 & 0,420 & $-0,205$ \\
\hline
\end{tabular}

Tabela 20. Estimativas dos parâmetros de estruturação genética obtidas para cada loco de aloenzimas amostrados da população de Trema micrantha, no dossel da RMSG.

\begin{tabular}{cccc}
\hline Locos & $\hat{f}$ & $\hat{F}$ & $\hat{\theta}_{P}$ \\
\hline Mdh-2 & $-0,037$ & $-0,043$ & $-0,006$ \\
Gdh-2 & 0,226 & 0,192 & $-0,044$ \\
Skdh & $-0,697$ & $-0,500$ & 0,116 \\
Dia-2 & $-0,221$ & $-0,173$ & 0,039 \\
Idh & 0,076 & 0,135 & 0,064 \\
Got & 0,015 & $-0,008$ & $-0,023$ \\
Média & $-0,186$ & $-0,140$ & 0,039 \\
& $(-0,441$ a 0,078$)$ & $(-0,321$ a 0,087$)$ & $(-0,010$ a 0,083$)$ \\
\hline
\end{tabular}

( ) Intervalo de confiança a 95\% de probabilidade obtido a partir de 1.000 bootstraps sobre subpopulações

Estas variaram de -0,079 a -0,322, sendo referentes aos locos Gdh-2 e Got. Enquanto é indicado grande proporção de heterozigotos nos locos e progênies analisados, o índice de fixação total dos mesmos locos indicam endogamia na população. As estimativas variam de 0,093 e 0,385, para os locos Got e Skdh, respectivamente, e a média sobre locos é significativamente diferente de zero. Para melhor entendimento desta variação, 
as estimativas de divergência entre progênies foram positivas e elevadas para todos os locos. A menor estimativa foi 0,236 para o locos Gdh-2, sendo bem próxima da esperada entre progênies de irmãos completos

Tabela 21. Estimativas dos parâmetros de diversidade genética intrapopulacional apresentados por subpopulações do banco de sementes de Trema micrantha amostrado na RMSG.

\begin{tabular}{ccccc}
\hline Subpopulações & $\mathrm{N}$ & $\hat{H}_{e}$ & $\hat{H}_{o}$ & $\hat{f}$ \\
\hline 1 & 19 & 0,413 & 0,433 & $-0,049$ \\
2 & 19 & 0,377 & 0,351 & 0,070 \\
3 & 18 & 0,350 & 0,290 & 0,175 \\
4 & 20 & 0,374 & 0,412 & $-0,107$ \\
5 & 14 & 0,457 & 0,535 & $-0,195$ \\
Média & 18,23 & 0,394 & 0,404 & $-0,027$ \\
\hline
\end{tabular}

Tabela 22. Estimativas dos parâmetros de estruturação genética obtidas para cada loco de aloenzimas amostrados do banco de sementes de Trema micrantha na RMSG.

\begin{tabular}{cccc}
\hline Locos & $\hat{f}$ & $\hat{F}$ & $\hat{\theta}_{P}$ \\
\hline Got & 0,241 & 0,228 & $-0,017$ \\
Dia-2 & $-0,267$ & $-0,098$ & 0,133 \\
Idh & 0,036 & 0,070 & 0,035 \\
Gdh-2 & 0,101 & 0,108 & 0,009 \\
Mdh-2 & $-0,049$ & 0,009 & 0,055 \\
Skdh & $-0,095$ & $-0,075$ & 0,018 \\
Média & $-0,020$ & 0,026 & 0,045 \\
& $(-0,163$ a 0,138$)$ & $(-0,060$ a 0,144$)$ & $(0,005$ a 0,091$)$ \\
\hline
\end{tabular}

( ) Intervalo de confiança a 95\% de probabilidade obtido a partir de 1.000 bootstraps sobre subpopulações 
Tabela 23. Estimativas dos parâmetros de diversidade genética intrapopulacional obtidas para cada progênie de Trema micrantha amostrada na RMSG.

\begin{tabular}{ccccc}
\hline Progênies & $\mathrm{n}$ & $\hat{H}_{e}$ & $\hat{H}_{o}$ & $\hat{f}$ \\
\hline 1 & 10 & 0,048 & 0,050 & $-0,038$ \\
2 & 10 & 0,394 & 0,517 & $-0,335$ \\
3 & 9 & 0,271 & 0,296 & $-0,099$ \\
4 & 10 & 0,104 & 0,117 & $-0,125$ \\
5 & 10 & 0,144 & 0,167 & $-0,169$ \\
6 & 7 & 0,290 & 0,342 & $-0,198$ \\
7 & 7 & 0,208 & 0,228 & $-0,109$ \\
8 & 9 & 0,171 & 0,212 & $-0,262$ \\
9 & 9 & 0,332 & 0,441 & $-0,355$ \\
Média & 9,26 & 0,218 & & $-0,225$ \\
\hline
\end{tabular}

Tabela 24. Estimativas dos parâmetros de estruturação genética obtidas para cada loco de aloenzimas amostrados das progênies de Trema micrantha da RMSG.

\begin{tabular}{cccc}
\hline Locos & $\hat{f}$ & $\hat{F}$ & $\theta_{P}$ \\
\hline Gdh-2 & $-0,079$ & 0,175 & 0,236 \\
Skdh & $-0,085$ & 0,385 & 0,433 \\
Idh & $-0,161$ & 0,332 & 0,425 \\
Mdh-2 & $-0,317$ & 0,341 & 0,500 \\
Dia-2 & $-0,272$ & 0,156 & 0,337 \\
Got & $-0,322$ & 0,093 & 0,314 \\
Média & $-0,231$ & 0,242 & 0,384 \\
& $(-0,298$ a $-0,130)$ & $(0,146$ a 0,348$)$ & $(0,326$ a 0,446$)$ \\
\hline
\end{tabular}

( ) Intervalo de confiança a 95\% de probabilidade obtido a partir de 1.000 bootstraps sobre subpopulações 


\subsection{Discussão}

As estimativas de diversidade genética foram altas e apresentaram diferenças entre os diferentes estádios de vida analisados. A população de plantas do dossel apresentou tendência a manter maior heterozigosidade do que o banco de sementes e as

progênies. As estimativas de heterozigosidade esperada foram menores do que as observadas, resultando em valores negativos para os coeficientes de endogamia médio intrapopulacional. Uma maior proporção de heterozigotos para a população de plantas em relação a outras estádios do ciclo de vida já foi encontrado para outras espécies (Schaal \& Levin, 1976; El-Kassaby et al. 1987; O’Malley et al. 1988; Eguiarte et al. 1992; Hamrick et al. 1993; Tonsor et al. 1993; Conte, 2001). Tal condição é normalmente associada à competição entre os descendentes nas fases de plântula, muda e juvenil. A condição de alta diversidade com excesso de heterozigotos pode ser relacionada à ação de seleção favorecendo a manutenção de genótipos heterozigotos atuando já no processo de germinação das sementes. Kalisz (1989) confirmou a associação da maior porcentagem de germinação entre heterozigotos em relação aos homozigotos, quando trabalhou com algumas espécies de plantas.

Variações nas estimativas dos parâmetros de diversidade e estruturação genética salientam a associação dos heterozigotos com o vigor de germinação e permanência das plântulas nesta população de T. micrantha. Primeiro, verifica-se um aumento na heterozigosidade observada nas subpopulações do banco de sementes comparativamente às progênies. À esta, pode se acrescentar a drástica redução na estimativa do índice de fixação total verificada novamente entre as fases de progênie e banco de sementes, indicando diminuição da endogamia total na população. Por último, pode-se considerar a manutenção das altas proporções de heterozigosidade observada e o aumento dos desvios em relação à esperada, verificados nas subpopulações de plantas do dossel em ralação àquelas do banco de sementes.

A população analisada como banco de sementes são plântulas resultantes da germinação das sementes existentes nas amostras da superfície de solo. Deve-se considerar que estas foram submetidas um processo de seleção tendo sido excluídos 
parte dos indivíduos endogâmicos ou menos vigorosos. Sob este aspecto, as progênies foram germinadas sob condições controladas de temperatura e fototropismo sendo, posteriormente, levadas para desenvolvimento em casa de vegetação. Mesmo as progênies tendo sido obtidas sob condições ambientais mais favoráveis para a germinação do que aquelas do banco de sementes, existiu grande mortalidade entre as plântulas da população de progênies, passando a contribuir para o aumento na proporção de heterozigotos nesta população.

Diante das considerações, a permanência das sementes no banco de solo pode ser considerada um fator chave na reposição da diversidade genética da população de plântulas. No entanto, os poucos resultados sobre o assunto demonstraram que o tempo de permanência das sementes de pioneiras no solo não é tão longo. A Cecropia obtusifolia, por exemplo, possui um banco de sementes com uma razão de renovação de 1,07 anos, sendo que, enquanto a grande maioria das suas sementes contam com uma média de vida de 7 dias, algumas podem alcançar muito mais idade (Alvarez-Buylla \& García-Barrios, 1991). Para esta espécie, considerou-se muito pouco provável que as sementes mantidas no solo ficassem o tempo suficiente para diminuir a divergência genética entre clareiras, dado que a taxa de renovação da espécie é muito rápida e muito poucas sementes são capazes de permanecer no solo de um ano para o outro (AlvarezBuylla et al. 1996). Plantago lanceolata é uma espécie herbácea com dormência de sementes e também foi estudada quanto a variações na estrutura genética em diferentes fases de vida. Os resultados não demonstraram diferenças significativas entre as estimativas para as sementes do solo em relação às plântulas (Tonsor et al. 1993). Para esta espécie a longevidade de suas sementes também é desconhecida.

As sementes de T. micrantha permanecem no solo na forma de diásporos, sendo o pericarpo espesso, garantindo proteção das suas sementes até mesmo contra patógenos (Torres, 1996). Os diásporos são bastante impermeáveis e podem ser armazenados por longos períodos sem perder o potencial de germinação. Não existem informações quanto a viabilidade dos mesmos em condições de solo, mas seu período de permanência e sua taxa de renovação no banco devem ser bem maior do que verificado para a C. obtusifolia devido a sensibilidade ao ataque de patógenos desta, quando lançada ao solo. Além 
disto, os diásporos precisaram ser tratados com ácido sulfúrico concentrado durante 20 minutos, no processo de obtenção das progênies para este estudo, sem que afetasse o potencial de germinação de uma porção considerável dos diásporos iniciais. De qualquer forma, são necessários estudos para se definir a permanência e a taxa de renovação do banco de sementes de T. micrantha para ter uma discussão mais embasada.

As estimativas dos parâmetros de estruturação genética apresentaram variações marcantes entre os diferentes estádios de ciclo de vida estudados. Na obtenção destas estimativas, cada clareira, onde se amostrou o solo e as plantas do dossel, foi analisada como uma população, sendo que, para a população de progênies, cada progênies foi uma população. Este detalhe é importante para entender as elevadas estimativas do índice de fixação total e divergência genética entre populações verificados para as progênies, enquanto estimativas bem próximas de zero foram encontradas para as populações do banco de sementes e das plantas do dossel.

T. micrantha produz grande quantidade de sementes resultantes de um sistema de cruzamento misto, com significativa freqüência de cruzamentos biparentais. Como consequiência, ocorre a elevação da proporção de genótipos repetidos e também em homozigose dentro das progênies. Sabendo-se disto, e diante das variações nas estimativas de divergência genética e do alto índice de fixação total para as progênies, verifica-se que o seu sistema reprodutivo é vulnerável à deriva genética. A ocorrência de deriva está associa ao assincronismo no florescimento entre as plantas reprodutivas e pela polinização ocorrer principalmente de forma restrita dentro de clareiras. Por outro lado, as variações também demonstram que a espécie conta com um eficiente fluxo gênico via sementes, devido à diminuição da divergência genética entre clareiras do banco, comparativamente à obtida para população de progênies.

O sistema reprodutivo desta espécie é marcado pelo assincronismo no florescimento mantido ao longo do seu período reprodutivo (Torres, 1996), o que resulta em variações nas freqüências alélicas do conjunto de pólens e óvulos entre clareiras. Assim, alelos pouco freqüentes na população de plantas do dossel podem ter mais freqüência nas progênies se aquelas plantas que possuem tais alelos participaram de forma efetiva no período reprodutivo em questão e vice-versa. Portanto, a variação na 
diversidade dentro e divergência genética entre clareiras está intimamente associada à deriva genética. A espécie, no entanto, também pode contar com uma dispersão por maiores distâncias por suas árvores serem freqüentemente encontradas nas bordas de fragmentos e nas florestas secundárias que predominam nas paisagens fragmentadas, estando as árvores mais expostas à ação do vento.

Seus frutos podem cair sob a copa de suas árvores, mas boa parte deles é dispersa por pássaros e animais, os quais podem distribuir os frutos por consideráveis distâncias. O amadurecimento dos frutos ocorre ao longo de várias semanas, o que favorece a visitação de dispersores quase diariamente (Torres, 1996) e estes visitam várias árvores dispostas também em diferentes clareiras. Considerando tais características, o fluxo gênico pode ser considerado eficiente o suficiente para alterar drasticamente a divergência genética verificada entre progênies, da mesma forma como alguns autores sugerem que o modo de dispersão de sementes afeta a estrutura genética espacial (Loveless \& Hamrick, 1984; Hamrick et al. 1993).

Como mencionado anteriormente, existe uma tendência para a seleção atuar ao longo dos diferentes estádios do ciclo de vida, sendo ela mais acirrada na fase inicial de regeneração devido à grande competição entre plântulas. No entanto, pode-se acreditar num processo de seleção diferenciada de genótipos, variando com as características microambientais nas diferentes clareiras. Sob tais condições, considera-se que a divergência genética entre as subpopulações de plantas, estando estas restritas às clareiras, tende a variar com a idade da clareira. Tal processo se baseia no fato das clareiras se tornarem internamente mais homogêneas e seletivas do que quando eram clareiras jovens (Martinéz-Ramos, 1992, citado por Alverez-Buylla et al. 1996). De qualquer forma, por se ter amostrado clareiras ao acaso, sem considerar a idade das mesmas, a competição e seleção provavelmente permanecem favorecendo a divergência genética entre os grupos de plantas restritos às clareiras, se tornando cada vez menos densa para as espécies do primeiro estágio sucessional.

A espécie pioneira $C$. obtusifolia também foi estudada quanto à estrutura genética de populações para diferentes estádios de vida (Alvarez-Buylla et al. 1996). Como seus agentes dispersores transportam sementes coletadas da mesma 
infrutescência, sendo estas normalmente dispersas de forma agregada, os autores encontraram correlações elevadas entre genótipos de plântulas amostradas nas clareiras recentes. Em contraste, entre plantas jovens e adultas se verificou apenas um pequeno agrupamento de indivíduos genotipicamente aparentados, prevalecendo a distribuição espacial próxima do acaso. Para esta espécie também foi considerado que, em cada geração, muito da estrutura é removida devido à competição individual num espaço limitado pela abertura do dossel e, com a seleção atuando conjuntamente, ocorrem flutuações na distribuição genotípica entre classes de idade (Epperson \& AlvarezBuylla,1997).

A ocorrência de estrutura em família resultante da dispersão de progênies próximo da árvore mãe é considerado comum entre espécies arbóreas (Libby et al. 1969) e, assim como foi proposto para a C. obtusifolia (Epperson \& Alvarez-Buylla, 1997), também pode ocorrer para T. micrantha. No entanto, os resultados obtidos pelos autores concordaram que a estruturação genética espacial varia com a idade da regeneração, e que os agrupamentos de progênies próximos à planta mãe são submetidos à competição e seleção, resultando numa diminuição dessa estrutura até formar nova população de adultos. Além disso, o fluxo gênico naquela espécie pioneira se mostrou eficiente o bastante para romper a estruturação espacial ao longo das gerações, diminuindo a possibilidade do isolamento por distância sobre repetidas gerações de ciclos de vida.

Esse aspecto pode ser considerado também para T. micrantha e explica os altos níveis de diversidade genética esperados em populações de espécies preferencialmente alogâmicas, que são polinizadas pelo vento e possuem sementes dispersas por animais, como citado por Hamrick et al. (1992). Justificando seu ponto de vista, os autores verificaram maiores estimativas de divergência genética entre clareiras para populações no estágio de plântulas do que juvenil ou adulto. Suas análises revelaram que esta variação foi devido a diferenças no grau de concentração de poucos genótipos específicos dentro de clareiras em relação aos diferentes estádios de vida.

T. micrantha se enquadra na condição de elevado recrutamento e, enquanto o agrupamento de progênies foi encontrado em espécies arbóreas tropicais, existem poucas 
evidências de estrutura entre adultos (Epperson \& Allard, 1989; Schnabel \& Hamrick, 1990; Perry \& Knowles, 1991), exceto para as populações de plantas com baixa dispersão de pólen e sementes (Epperson \& Clegg, 1986; Schoen \& Latta, 1989). Tais resultados, vistos como discrepantes por alguns autores, podem ser explicadas simplesmente pela redução do número de indivíduos diante da competição. Com a mesma idéia, Epperson (1992) justifica que a elevada densidade de sementes ou plântulas no estágio inicial de regeneração em relação aos pais favorece altas taxas de correlação genética entre as mudas, mas é esperado que esta diminua bruscamente com o desenvolvimento das plantas, tendendo a ser eliminada.

A população amostrada neste estudo está inserida numa paisagem amplamente urbanizada. Os resultados demonstram que a diversidade genética presente no banco é satisfatória para representar a alta diversidade existente na população do dossel da floresta, expondo a plasticidade da espécie em se estabelecer em condições de paisagem bastante alterada. Dessa forma, a alta diversidade mantida na população justifica a agressividade da espécie T. micrantha para colonizar diferentes ambientes ao longo da sua grande área de ocorrência, bem como em projetos de restauração de vegetação sob diferentes condições edafoclimáticas.

\subsection{Conclusões}

A população de Trema micrantha estudada apresenta elevada diversidade genética nos três estádios de vida analisados. No entanto, as plantas do dossel e as sementes do banco de solo mantêm maior diversidade genética, estando ela bem distribuída nas clareiras.

Os agentes dispersores de sementes e a permanência de sementes no banco do solo são os prováveis responsáveis pela drástica redução na estruturação genética presente na população de progênies, sendo eles fundamentais na distribuição da diversidade genética sobre grandes áreas de ocorrência. 
Diferenças entre os estádios de vida estudados, sugerem que a acirrada competição entre plântulas e mudas, principalmente durante o período inicial da regeneração, resulta em forte seleção favorecendo a manutenção de alta diversidade na população de plantas do dossel e redução da endogamia presente na população de progênies.

Os resultados indicam que a espécie apresenta elevada eficiência adaptativa para colonização e permanência em paisagens intensamente alteradas, coerente para espécies pioneiras. 


\section{CONCLUSÕES GERAIS}

Os resultados obtidos permitem concluir que:

Trema micrantha possui sistema de cruzamento misto com predomínio de fecundação cruzada. Seus indivíduos são dispostos de forma estruturada no espaço e boa parte dos indivíduos em suas progênies resultam de cruzamentos biparentais, sendo irmãos completos.

Diferenças entre os estádios de vida estudados em uma população de Trema micrantha, sugerem que a acirrada competição entre plântulas e mudas, principalmente durante o período inicial da regeneração, resulta em forte seleção favorecendo a manutenção de alta diversidade na população de plantas do dossel e redução da endogamia presente na população de progênies.

Os agentes dispersores de sementes e a permanência de sementes no banco do solo são os prováveis responsáveis pela drástica redução na estruturação genética presente na população de progênies, comparativamente à população do banco de sementes e de plantas do dossel.

Como prováveis efeitos da fragmentação e alteração da vegetação, Trema micrantha tende a manter maior endogamia em suas populações e apresentar maiores proporções de cruzamentos correlacionados. No entanto, ela apresenta elevada eficiência adaptativa para colonização e permanência em paisagens intensamente alteradas, coerente para espécies pioneiras. 
Cecropia pachystachya, que é espécie dióica, também pode apresentar indivíduos estruturados espacialmente em famílias, favorecendo cruzamentos entre indivíduos aparentados. A grande maioria dos indivíduos compondo suas progênies são resultantes de cruzamentos biparentais, sendo irmãos completos.

As espécies pioneiras arbóreas Trema micrantha e Cecropia pachystachya apresentam alta diversidade genética em suas populações. O fluxo gênico entre e dentro das populações é realizado de forma a garantir maior diversidade dentro do que entre populações. A disposição de indivíduos em clareiras é favorável para manutenção da alta diversidade genética nas espécies. 


\section{REFERÊNCIAS BIBLIOGRÁFICAS}

AIZEN, M.A.; FEINSINGER, P. Forest fragmentation, pollination, and plant reproduction in a chaco dry forest, Argentina. Ecology, v.75, n.2, p.330-351, 1994.

ALDRICH, P.R.; HAMRICK, J.L. Reproductive dominance of pasture trees in a fragmented tropical mosaic. Science, v.281, p.103-105, 1998.

ALFENAS, A.C.; BRUNE, W.; OLIVEIRA, J.R.; ALONSO, S.K.; SCORTINCHINI, M. Eletroforese de proteínas para eletroforese. In: ALFENAS, A.C. (Ed.). Eletroforese de isoenzimas e proteínas afins: fundamentos e aplicações em plantas e microrganismos. Viçosa: UFV, 1998. p.85-114.

ALFENAS, A.C.; PETERS, I.; BRUNE, W.; PASSADOR, G.C. Eletroforese de proteínas e isoenzimas de fungos e essências florestais. Viçosa: UFV, 1991. 242p.

ALVAREZ-BUYllA, E.R.; CHAOS, A.; PIÑERO, D.; GARAY, A.A. Demographic genetics of a pioneer tropical tree species: patch dynamics, seed dispersal, and seed banks. Evolution, v.50, n.3, p.1155-1166, 1996.

ALVAREZ-BUYLLA, E.R.; GARAY, A.A. Population genetic structure of Cecropia obtusifolia, a tropical pioneer species. Evolution, v.48, n.2, p.437-453, 1994.

ALVAREZ-BUYLLA, E.R.; GARCÍA-BARRIOS, R. Seed and forest dynamics: a theoretical frameword and an example from the Neotropics. The American Naturalistic, v.137, p.133-154, 1991. 
ALVAREZ-BUYLLA, E.R.; MARTÍNEZ-RAMOS, M. Seed bank versus seed rain in the regeneration of o tropical pioneer tree. Oecologia, v.84, p.314-325, 1990.

ANDERSON, G.J.; STEBBINS, G.L. Dioecy versus gametophytic sef-incompatibility: a test. The American Naturalistic, v.124, p.423-428, 1984.

ASHTON, P.S. Speciation amog tropical forest trees: some deductions in the light of recent evidence. Biological Journal of Linnean Society, v.1, p.155-196, 1969.

BAKER, H.G. Self-compatibility and establishement after "long-distance" dispersal. Evolution, v.9, p.347-348, 1955.

BARRETT, S.C.H.; CHARLESWORTH, D. Effects of change in the level of inbreeding on the genetic load. Nature, v.352, p.522-524, 1991.

BAWA, K.S. Breeding systems of tree species of a lowland tropical community. Evolution, v.28, p.85-92, 1974.

BAWA, K.S. Plant-pollinator interaction in tropical rain forest. Anual Review of Ecology and Systematics, v.21, p.399-422, 1990.

BAWA, K.S.; BULLOCK, S.H.; PERRY, D.R.; COVILLE, R.E.; GRYUM, M.H. Reproductive biology of tropical lowland rain forest trees. II. Pollination systems. American Journal of Botany, v.72, p.346-356, 1985a.

BAWA, K.S.; KRUGMAN, S.L. Reproductive biology and renetics of tropical trees in relation to conservation and management. In: GÓMEZ-POMPA, A.; WHITMORE, T.C.; HADLEY, M. Rain forest regeneration and management (Man and the biosphere series, 6), Paris: UNESCO, 1991. p.119-136.

BAWA, K.S.; PERRY, D.R. BEACH, J.H. Reproductive biology of tropical lowland rain forest trees. I. Sexual systems and incompatibility mechanisms. American Journal of Botany, v.72, p.331-345, 1985b. 
BAZZAZ, F.A. Regeneration of tropical forests: physiological responses of pioneer and secondary species. In: GÓMEZ-POMPA, A.; WHITMORE, T.C.; HADLEY, M. Rain forest regeneration and management (Man and the biosphere series, 6), Paris: UNESCO, 1991. p.91-118.

BENITEZ-MALVIDO, J. Impact of forest fragmentation on seedling abundance in a tropical rain forest. Conservation Biology, v.12, p.380-389, 1998.

BENITES-MALVIDO, J.; GARCÍA-GUZMAN, G.; KOSSMANN-FERRAZ, I.D. Leaf fungal incidence and gerbivory on tree seedlings in tropical rainforest fragments: an experimental study. Biological Conservation, v.91, p.143-150, 1999.

BOSHIER, D.H.; CHASE, M.R.; BAWA, K.S. Population genetics of Conria alliodora (Borraginaceae), a neotropical treee: gene flow, neighborhood, and population substructure. American Journal of Botany, v.82, n.4, p.484-490, 1995.

BROWN, A.H.D.; ALLARD, R.W. Estimation of tree mating system in open-pollinated maize populations using isozyme polymorphisms. Genetics, v.66, n.1, p.133-145, 1970.

BROWN, A.H.; MARSHALL, D.R. Evolutionary chages accompanying colonization in plants. In: SCUDDER, G.E.C.; REVEAL, J.L. (Ed.). Evolution today. Pittsburgh: Carnegie-Mellon University, Hunt Institute for Botanical Documentation, 1981. p.351-363.

BRUNA, E.M. Seed germination in rainforest fragments. Nature, v.402, p.139, 1999.

BUDOWSKI, G. Distributon of tropical american rain forest species in the light of sucessional processes. Turrialba, v.15, n.1, p.40-42, 1965.

CARVALHO, P.E.R. Espécies florestais brasileiras: recomendações silviculturais, potencialidades e uso da madeira. Colombo: EMBRAPA, CNPF, 1994. 640p. 
CASCANTE, A.; QUESADA, M.; LOBO, J.J.; FUCHS, E.A. Effects of dry tropical forest fragmentation on the reproductive success and genetic structure of the tree Samanea saman. Conservation Biology, v.16, n.1, p.137-147, 2002.

CHASE, M.R.; MOLLER, C.; KESSELI, R.; BAWA, K.S. Distant gene flow in tropical trees. Nature, n.383, p.398-9, 1996.

CLEGG, M.T. Measuring plant mating systems. Bioscience, v.30, p.814-818, 1980.

COCKERHAM, C.C.; WEIR, B.S. Estimation of gene flow from F-statistics. Evolution, v.47, n.3, p.855-863, 1993.

COELHO, A.S.G. Abordagem bayesiana na análise genética de populações utilizando dados de marcadores moleculares. Piracicaba, 2002. 76p. Tese (Doutorado) Escola Superior de Agricultura “Luiz de Queiroz”, Universidade de São Paulo.

COHEN, D. Optimizing reprodution in a randomly varying environment. Journal of Theoretical Biology, v.12, p.119-129, 1966.

CONTE, R. Genética do cruzamento de plantas em uma população natural do palmiteiro (Euterpe edulis Mart.). Florianópolis, 2001. 104p. Dissertação (Mestrado) Universidade Federal de Santa Catarina.

CUNNINGHAM, S.A. Effects of habitat fragmentation on the reproductive ecology of four plant species in Mallee Woodland. Conservation Biology, v.14, p.758-768, 2000.

DURIGAN, G.; FIGLIOLIA, M.B.; KAWABATA, M.; GARRIDO, M.A. de O.; BAITELLO, J.B. Sementes e mudas de árvores tropicais. 2. ed. São Paulo: Instituto Florestal, CINP, SMA, JICA, 2002. 65p.

EGUIARTE, L.E.; PÉREZ, N.N.; PIÑERO, D. Genetic structure, outcrossing rate and heterosis in a tropical palm, Astrocaryum mexicanum: implications for evolution and conservation. Heredity, v.69, p.217-228, 1992. 
EL-KASSABY, Y.A.; MEAGHER, M.D.; PARKINSON, J.; PORTLOCK, F.T. Allozyme inheritance, heterozygosidty and outcrossing rate among Pinus monticola near Ladysmith, British Columbia. Heredity, v.58, p.173-181, 1987.

ELLSTRAND, N.C. Gene flow among seed plant populations. New Forests, v.6, p.241256, 1992.

ELLSTRAND, N.C.; ELAM, D.R. Population genetic consequences of small population size: implications for plant conservation. Annual Review of Ecology and Systematics, v.24, p.217-242, 1993.

EPPERSON, B.K. Spatial structure of genetic variation within poulations of forest trees. New Forests, v.6, p.257-278, 1992.

EPPERSON, B.K.; ALLARD, R.W. Spatial autocorrelation analysis of the distribution of genotypes within poulation of lodgepole pine. Genetics, v.121, p.369-377, 1989.

EPPERSON, B.K.; ALVAREZ-BUYLLA, E.R. Limited seed dispersal anda genetic structure in life stages of Cecropia obtusifolia. Evolution, v.51, n.1, p.275-282, 1997.

EPPERSON, B.K.; CLEGG, M.T. Spatial autocorrelation analysis of flower color polymorphisms within substruture populations of morning glory (Ipomoea purpurea). The American Naturalistic, v.128, p.840-858, 1986.

FORÉ, S.A.; HICKEY, R.J.; VANKAT, J.L.; GUTTMAN, S.I.; SCHAEFER, R.L. Genetic structure after forest fragmentation: a landscape ecology perspective on Acer saccharum. Canadian Journal of Botany, v.70, p.1659-68, 1992.

FRIEDMAN, S.T.; ADAMS, W.T. Estimation of gene flow into two seed orchards of loblolly pine (Pinus taeda L.). Theoretical Applied Genetics, v.69, p.609-615, 1985. 
HALL, P.; WALKER, S.; BAWA, K. Effect of forest fragmentation on genetic diversity and mating system in a tropical tree, Pithecellobium elegans. Conservatin Biology, v.10, p.757-68, 1996.

HAMRICK, J.L. Isozymes and the analysis of genetic structure in plant populations. In: SOLTIS, D.E.; SOLTIS, P.S. (Ed.). Isozymes in plant biology. Portland: Dioscorides Press, 1989. p.87-105.

HAMRICK, J.L.; GODT, M.J.W.; SHERMAN-BROYLES, S.L. Factors influencing levels of genetic diversity in woody plant species. New Forests, v.6, p.95-124, 1992.

HAMRICK, J.L.; LOVELESS, M.D. Genetic structure of tropical populations: associations with reproductive biology. In: BROCK, J.H. ; LINHART, Y.B. (Ed.). The evolutinary ecology of plants. Boulder CO: Westview Press, 1989. p.215-248.

HAMRICK, J.L.; LOVELESS, M.D. Isozyme variation in tropical trees: procedures and preliminary results. Biotropica, v.18, n.3, p.201-207, 1986.

HAMRICK, J.L. Plant population genetics and evolution. American Journal of Botany, v.69, n.10, p.1685-1693, 1982.

HAMRICK, J.L.; LINHART, Y.B.; MITTON, J.B. Relationships between life history characteristics and electrophoretically detectable genetic variation in plants. Annual Review Ecology Systems, v.10, p.173-200, 1979.

HAMRICK, J.L.; MURAWSKI, D.A. The breeding structure of tropical tree populations. Plant Species Biology, v.5, p.157-165, 1990.

HAMRICK, J.; MURAWSKY, D.A.; NASON, J.D. The influence of seed dispersal mechanisms on the genetic structure of tropical tree populations. Vegetatio, v.107/108, p.281-297, 1993. 
HEDRICK, P.W. Purging inbreeding depression and the probability of extinction: fullsib mating. Heredity, v.73, p.363-372, 1994.

HOWE, H.F. Implications of seed dispersal by animals for tropical reserve management. Bilogical Conseration, v.30, p.261-281, 1984.

HYATT, L.; CASPER, B.B. Seed bank formation during early secondary succession in a temperate deciduous dorest. Journal of Ecology, v.88, p.516-527, 2000.

Instituto Brasileiro de Geografia e Estatística. Mapa de vegetação do Brasil. Rio de Janeiro, 1993.

JANZEN, D.H. Ecologia vegetal nos trópicos. São Paulo: EDUSP: Editora da Universidade de São Paulo, 1980. p.21-30.

JANZEN, D.H. No park is na island: increase in interference from ouside as park size decreases. Oikos, v.41, p.402-410, 1983.

JENNERSTEN, O. Pollination in Dianthus deltoides (Caryophyllaceae): effects of habitat fragmentation on visitation and seed set. Conservation Biology, v.2, p.359366, 1988.

KARRON, J.D.; THUMSER, N.N.; TUCKER, R.; HESSENAUER, A.J. The influence of population density on outcrossing rates in Mimulus ringens. Heredity, v.75, p.175-180, 1995.

KAGEYAMA, P.Y.; GANDARA, F.B.; OLIVEIRA, R.E.O.; MORAES, L.F.D. Restauração de mata ciliar: manual de recuperação de áreas ciliares e microbacias. Rio de Janeiro: Semads, 2001. 104p.

KALISZ, S. Fitness consequences of mating system, seed weight and emergence date in a winter annual, Collinsia verna. Evolution, v.43, p.1263-1272, 1989. 
KAUFMAN, S.R.; SMOUSE, P.E.; ALVAREZ-BUYLLA, E.R. Pollen-mediated gene flow and differential male reproductive succes in a tropcial pioneer tree, Cecropia obtusifolia Bertol. (Moraceae): a paternity analysis. Heredity, v.81, p.164-173, 1998.

KLEIN, B.C. Effects of forest fragmentation on dung and carrion beetle communities in central Amazonia. Ecology, v.70, p.1715-1725, 1989.

LAND, R. Neutral theory of quantitative genetic variance in na island model with local extincion and colonisation. Evolution, v.46, p.381-9, 1992.

LAURANCE, W.F.; FERREIRA, L.V.; RANKIN-de MERONA, J.M.; LAURANCE, S.G. Rain forest fragmentation and the dynamics of Amazonian tree communities. Ecology, v.79, p.2032-2040, 1998.

LEITÃO-FILHO, H.F. A vegetação. In: LEITÃO-FILHO, H.F.; MORELLATO, L.P. (Ed.). Ecologia e preservação de uma floresta tropical urbana-Reserva de Santa Genebra. Campinas: Editora da Unicamp, 1995. p.19-29.

LEVIN, D.A. The seed bank as a source of genetic novelty in plants. The American Naturalistic, v.135, p.563-572, 1990.

LEVIN, D.A.; KERSTER, H.W. Gene flow in seed plants. Evolutionary Biology, v.7, p.139-220, 1974.

LEWIS, P.O.; ZAYKIN, D. Genetic date analysis: computer program for the analysis of alletic data. Version 1.0. http://alleyn.eeb.uconn.edu/gda/2000 (16 jun. 2003)

LIBBY, W.F.; STETTLER, R.F.; SEITZ, F.W. Forest genetics and forest tree breeding. Annual Review Genetic, v.3, p.469-494, 1969.

LORENZI, H. Árvores brasileiras: manual de identificação e cultivo de plantas arbóreas nativas do Brasil. Odessa: Pantarum, 1992. 360p. 
LOVELESS, M.D. Isozyme variation in tropical trees, patterns of genetic organization. New Forests, v.6, p.67-94, 1992.

LOVELESS, M.D.; HAMRICK, J.L. Distribución de la variación en especies de árbores tropicales. Revista de Biologia Tropical, v.35, Supl.1, p.165-175, 1987.

LOVELESS, M.D.; HAMRICK, J.L. Ecological determinants of genetic structure in plant populations. Annual Review Ecology Systems, v.15, p.65-95, 1984.

MARTÍNEZ-RAMOS, M. Patrones, procesos y estructura en la comunidad de plántulas de la selva de los Tuxtlas (México). Mexico. 1992. Thesis (Ph.D) - Centro de Ecología, Uiversidad Nacional Autónoma de México. 147p.

MENGES, E.S. Seed germination percentage increases with population size in a fragmented prairie species. Conservation Biology, v.5, p.158-164, 1991.

MILLER, M.P. Tools for population genetics analyses (TFPGA) 1.3: a windows program for the analyses of allozyme and molecular population genetic data. (Software) Distributed by author, 1997.

MURAWSKI, D.A.; DAYANANDAN, B.; BAWA, K.S. Outcrossing rates of two endemic Shorea species from Sri Lankan tropical rain forests. Biotropica, v.26, n.1, p.23-29, 1994.

MURAWSKI, D.A.; HAMRICK, J.L. The mating system of Cavanillesia platanifolia under extremes of flowering-tree density: a test of predictions. Biotropica, v.24, p.99-101, 1992a.

MURAWSKI, D.A.; HAMRICK, J.L. Mating system and phenology of Ceiba pentandra (Bombacaceae) in Central Panama. Journal of Heredity, v.83, p.401404, 1992b. 
MURAWSKI, D.A.; HAMRICK, J.L.; HUBBELL, S.P.; FOSTER, R.B. Mating systems of two bombacaceous trees of a neotropical moist forest. Oecologia, v.82, p.501-506, 1990.

MURCIA, C. Edge effects in fragmented forests: implications for conservation. Trends in Ecology and Evolutin, v.10, p.58-62, 1995.

MYERS, N. Tropical deforestation: the latest situation. BioScience, v.41, p.282, 1991.

MYERS, N. Tropical deforestation and a mega-extinction spam. In: SOULÉ, M.E. (Ed.). Conservation biology: the science of scarcity and diversity, p.394-409. Sunderland: Sinauer Associates, 1986.

NASON, J.D. ; HAMRICK, J.L. Reproductive and genetic consequences of forest fragmentation: two case studies of neotropical canopy trees. Journal of Heredity, v.88, p.264-76, 1997.

O’MALLEY, D.M.; PRANCE, G.T.; BAWA, K.S. Genetics of Brazil nut (Bertholletia excelsa Humb \& Bonpl.: Lecythidaceae). 1. Mating system. Theoretical Applieance Genetics, v.76, p.929-936, 1988.

PAKE, C.E.; VENABLE, D.L. Is coexistence of Sonoran Desert annuals mediated by temporal variability in reproductive success. Ecology, v.76, p.246-261, 1995.

PERECIN, M.B. Diversidade genética em populações naturais de espécies de espinheira-santa, Maytenus aquifolia Mart. e M. ilicifolia Mart. ex Reiss. Piracicaba, 2000. 134p. Tese (Doutorado) - Escola Superior de Agricultura “Luiz de Queiroz”, Universidade de São Paulo.

PERRY, D.J.; KNOWLES, P. Spatial genetic structure within three sugar maple (Acer saccharum Marsh.) stands. Heredity, v.66, p.137-142, 1991.

POWEL, H.A.; POWELL, G. Population dynamics of male Euglossini bees in Amazonian Forest Fragments. Biotropica, v.19, p.176-179, 1987. 
PRIMACK, R.B.; RODRIGUES, E. Biologia da conservação. Londrina: E. Rodrigues. 2001. 328p.

PROBER, S.M.; BROWN, A.H.D. Conservation of the grassy white box woodlandspopulation genetics and fragmentation of Eucalyptus albens. Conservation Biology, v.8, p.1003-1013, 1994.

PULliAM, H.R. Sources, sinks and population regulation. The American Naturalistic, v.132, p.652-661, 1988.

RAYMOND, M.; ROUSSET, F. An exact test for population differentiation. Evolution, v.49, p.1280-1283, 1995.

RITLAND, K. Estimation of mating systems. In: TANKSLEY, S.D.; ORTON, T.J. Isozymes in plant genetics and breeding, Part A. Amsterdam: Elsevier, 1983. p.289-303.

RITLAND, K. Correlated matings in the partial selfer. Evolution, v.43, n.4, p.848-859, 1989.

RITLAND, K. Multilocus mating system progam MLTR. Version 1.1. (Software) Canada: University of 1994. http://forgen.forestry.ube.ca/ritland/dermit.html (16 jun. 2003)

RITLAND, K.; EL-KASSABY, Y.A. The nature of inbreeding in a seed orchard of Douglas fir as shown by na efficient multilocus model. Theoretical Applied Genetics, v.71, n.3, p.375-384, 1985.

RITLAND, K.; JAIN, S. A model for the estimation of outocrossing rate and gene frequencies using n independent loci. Heredity, v.47. n.1, p.35-52, 1981. 
ROHLF, F.J.; SCHNELL, G.D. An investigation of te isolationby distance model. The American Naturalistic, v.105, p.295-324, 1971.

SANTOS, E.M.G. Ecologia da Polinização, Fluxo de Pólen e Taxa de Cruzamento em Bauhinia forficata Link. Piracicaba, 1994. 123p. Dissertação (Mestrado) - Escola Superior de Agricultura “Luiz de Queiroz”, Universidade de São Paulo.

SAUNDERS, D.A.Jr.; HOBBS, R.J.; MARGULES, C.R. Biological consequences of ecosystem fragmentation: a review. Conservation Biology, v.5, p.18-32, 1991.

SAYER, J.A.; WHITMORE, T.C. Tropical moist forests: destruction and species extinction. Biological Conservation, v.55, p.199-213, 1991.

SHAFFER, M.L. Minimum population sizes for species conservation. BioScience, v.31, p.131-134, 1981.

SCHIMIDT-ADAM, G.; YOUNG, A.; MURRAY, B.G.M. Low outcrossing rates and pollinator shift in New Zealand Pohutukawa (Metrosideros excelsa) (Myrtaceae). American journal of Botany, v.87, n.9, p.1265-1271, 2000.

SCHAAL, BA.; LEVIN, DA. The demographic genetics of Liatris cylindracaea Michx. (Compositae). The American Naturalistic, v.110, p.191-206, 1976.

SCHNABEL, A.; HAMRICK, J.L. Organization of genetic diversity wighin and among populations of Gleditsa triacanthos (Leguminosae). American Journal of Botany, v.77, p.1060-1069, 1990.

SHOEN, D.J.; LATTA, R.G. Spatial autocorrelation of genotypes in populations of Impatiens pallida and Impatiens capensis. Heredity, v.63, p.181-189, 1989.

SIH, A.; BALTUS, M.S. Patch size, pollinator behavior and pollinator limitation in catnip. Ecology, v.68, p.1679-1690, 1987. 
SLATKIN, M. Gene flow in natural populations. Annual Review of Ecology and Systematics, v.16, p.393-430, 1985.

SLATKIN, M. Gene flow and the geographic structure of natural populations. Science, v.236, p.787-792, 1987.

STEBBINS, G.L. Self fertilization and population variability in higher plants. The American Naturalistic, v.91, p.337-354, 1957.

SUN, M.; RITLAND, K. Mating system of yellow starthistle (Centaurea solstitialis), a successful colonizer in North America. Heredity, v.80, p.225-232, 1998.

TONSOR, S.J.; KALISZ, S.; FISHER, J.; HOLTSFORD, T.P. A life-history based study of population genetic structure: seed bank to adults in Plantago lanceolata. Evolution, v.47, n.3, p.833-843, 1993.

TORRES, R.B. Biologia da Reprodução de Trema micrantha (L.) Blume (Ulmaceae). Campinas, 1996. 140p. Tese (Doutorado) - Universidade Estadual de Campinas.

TURNER, M.E.; STEPHENS, J.C.; ANDERSON, W.W. Homozygosity and patch structure in plant populations as a result of nearest-neighbor pollination. Procceddings of the National Academy of Sciencew. v.79, p.203-207, 1982.

UHL, C.; BUSCHBACHER, R.; SERRÃO, E.A.S. Abandoned pastures in Eastern Amozonia: patterns of plants succession. Journal of Ecolgy, v.76, p.663-681, 1988.

VENABLE, D.L.; BROWN, J.S. The selective interactions of dispersal, domancy, and seed size as adaptations for reducing risk in variable environments. The American Naturalistic, v.131, p.360-384, 1988.

VIANA, V.M. Seed and seedling availability as a basis for management of natural forest regeneration. In: ANDERSON, A.B. Alternatives to deforestation: steps toward 
sustainable use of the Amazon Rain Forest. New York: Columbia University Press, 1990. p.99-115.

WIESENMÜLLER, J.; DENICH, M.; VLEK, P.L.G. Regeneração vegetativa de capoeira na região de Amazônia Oriental, Brasil. In: KANASHIRO, M.; PARROTA, J.A. (Ed.). Manejo e reabilitação de áreas degradadas e florestas secundárias na Amazônia. Belém: Embrapa, 1995. p.101-105.

WADE, M.J.; McCAULEY, D.E. Extinction and colonisation: their effects on the genetic differentiation of local populations. Evolution, v.42, p.995-1005, 1998.

WEIR, B.S. Genetic data analysis: methods for discrete population genetic data. Suderland: Sinauer, 1996. 377p.

WHITLOCK, M.C. Temporal fluctuations in demographic parameters and the genetic variance among populations. Evolution, v.46, p.608-615, 1992.

WHITMORE, T.C. Tropical rain forest dynamicas and its implications for management. In: GÓMEZ-POMPA, A.; WHITMORE, T.C.; HADLEY, M. (Ed.). Rain forest regeneration and management (Man and the biosphere series, 6), Paris: UNESCO, 1991. p.67-90.

WRIGHT, S. Evolution in Mendelian populations. Genetics, v.16, p.97-159, 1931.

YOUNG, A.G.; BOYLE, T.J. Forest fragmentation. In: YOUNG, A.; BOSHIER, D.; BOYLE, T. Forest conservation genetics: principles and practice; Oxford: CSIRO, 2001. p.123-134.

YOUNG, A.G.; BROWN, A.H.D.; ZICH, F.C. Genetic structure of fragmented populations of the endangered grassland daisy Rutidosis leptorrhynchoides. Conservation Biology, v.13, p.256-265, 1999. 
YOUNG, A.G.; MERRIAM, H.G.; WARWICK, S.I. The effects of forest fragmentation on genetic variation in Acer saccharum Marsh. (sugar maple) populations. Heredity, v.71, p.277-89, 1993. 
APÊNDICE 1 - Zimogramas resultantes de eletroforese horinzontal em gel de amido para sistemas enzimáticos empregados com Trema micrantha(L.)B.
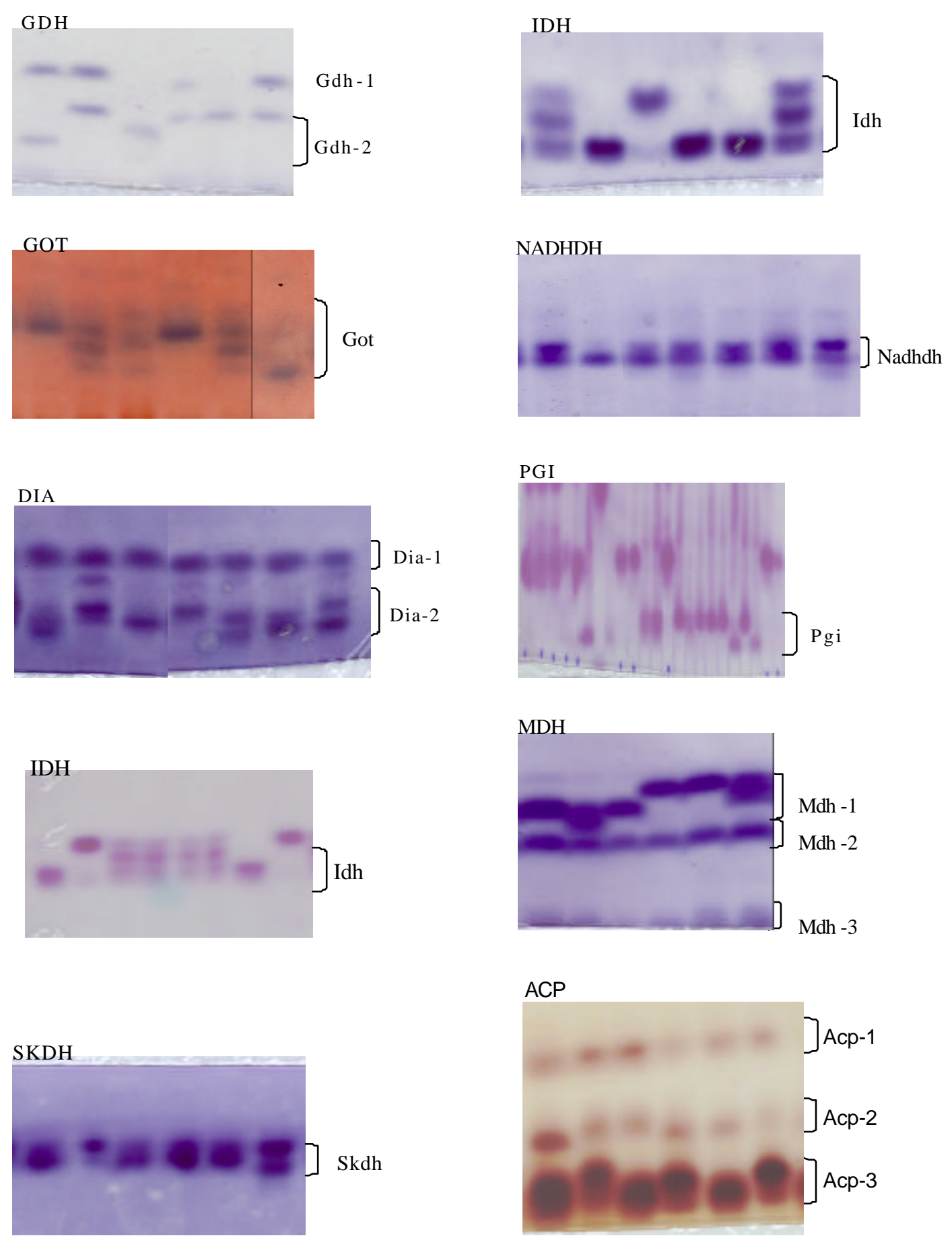
APÊNDICE 2 - Zimogramas resultantes de eletroforese horinzontal em gel de amido para sistemas enzimáticos empregados com Cecropia pachystachya Trec.
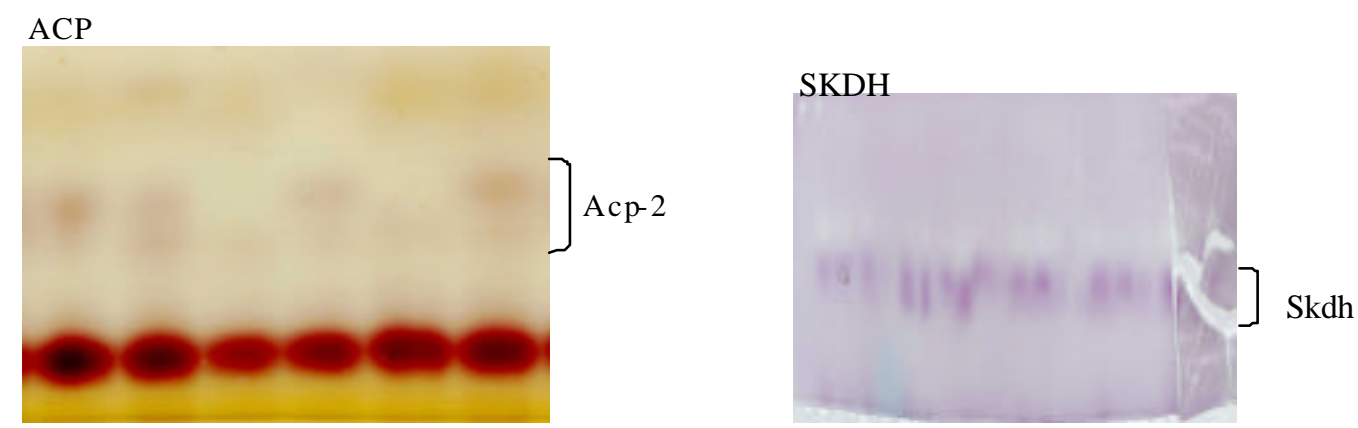

PGI

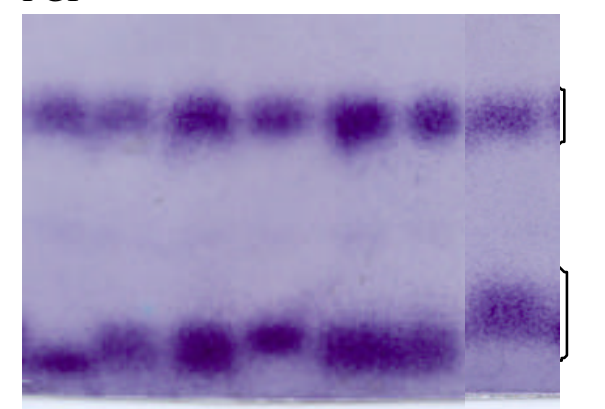

Pgi-1

IDH
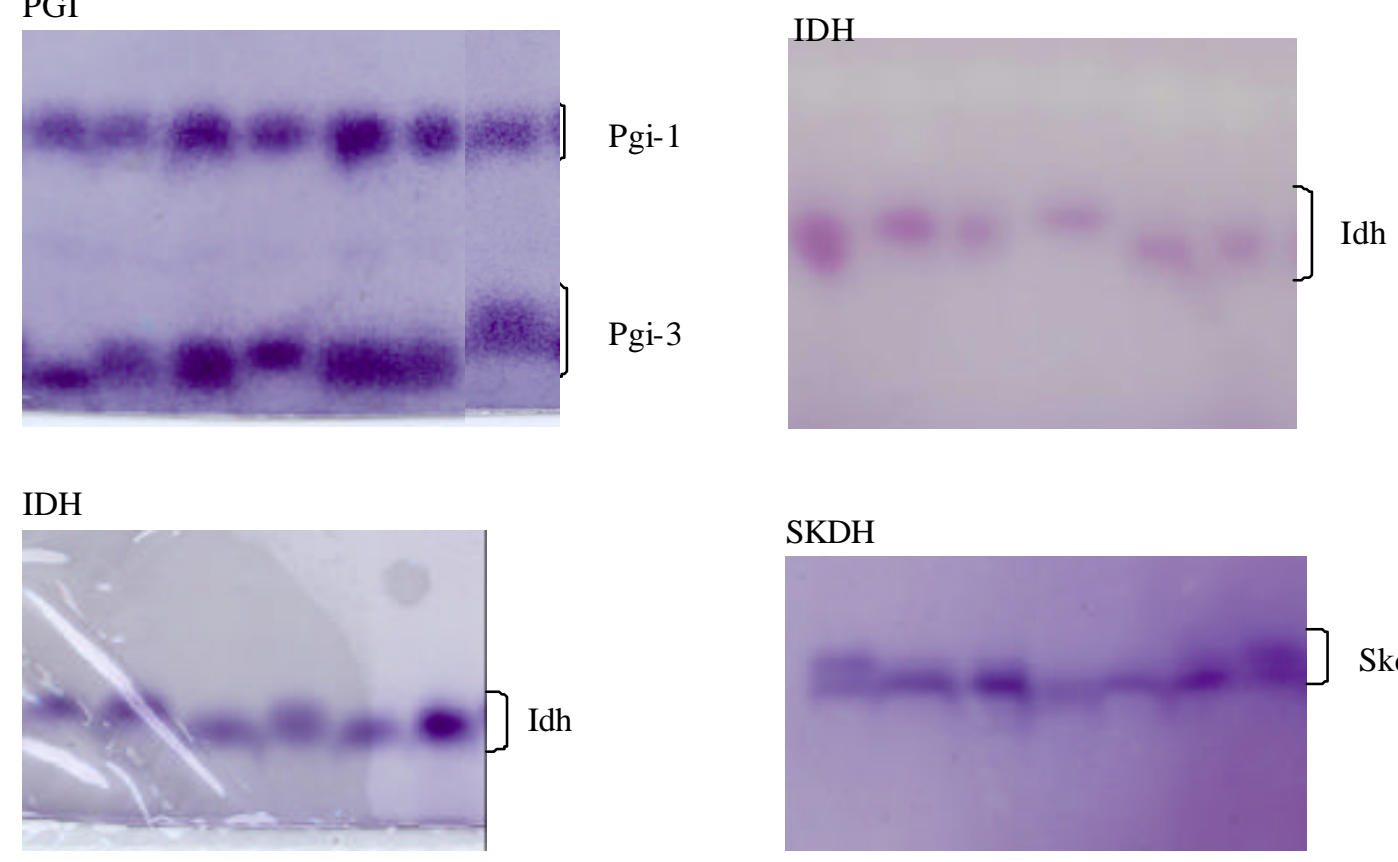

\section{SKDH}
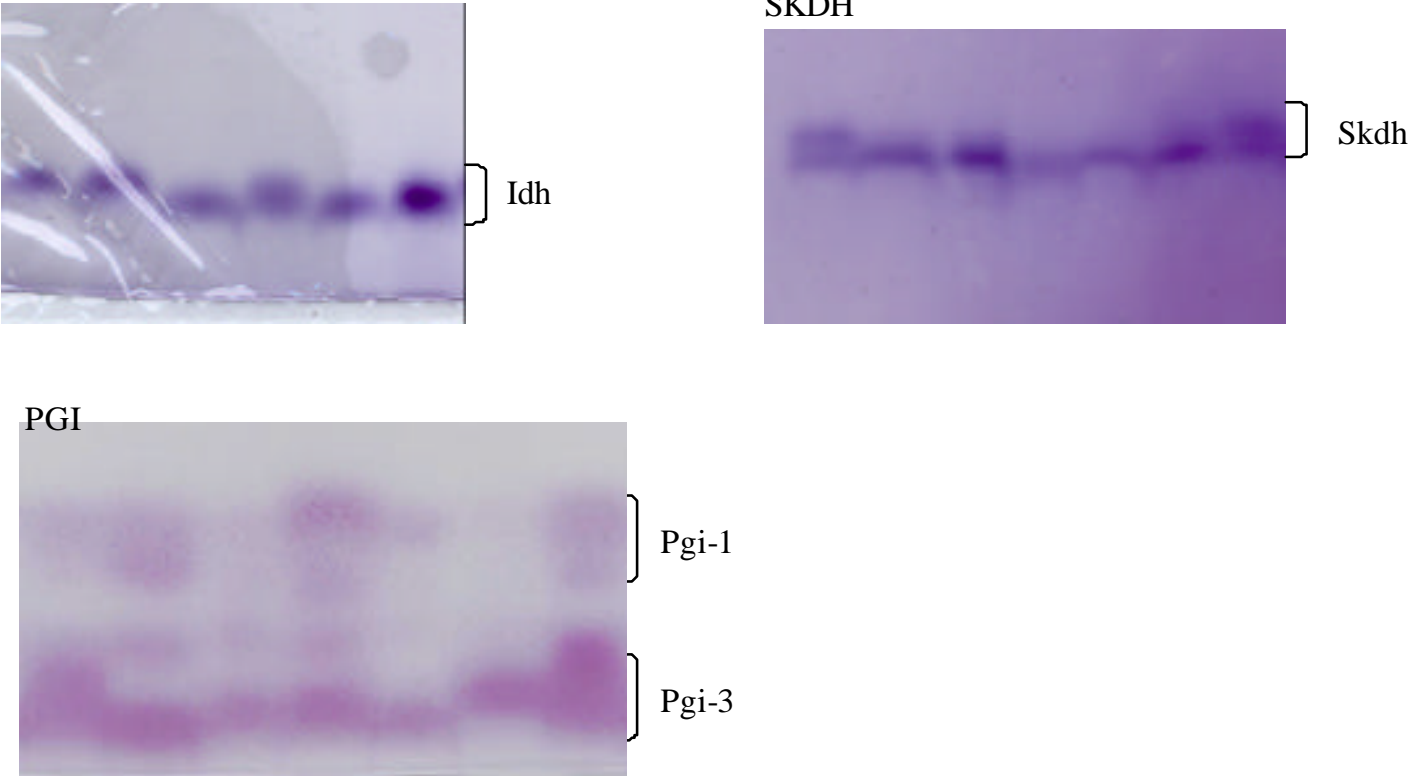